Description of two new genera

and ten new species of Metarbelidae (Lepidoptera: Cossoidea)

from western, north-central and eastern Africa

with notes on habitats and biogeography

Ingo Lehmann

Published by the author 
Author:

Ingo Lehmann

Produced by:

S\&K NEUE Hamburger Digitaldruck

+ Medien GmbH

Hamburg - Germany

This publication may be ordered from the author.

Date of publication:

$25^{\text {th }}$ March 2013

Copyright (C) 2013

The author

All rights reserved.

No part of this publication may be reproduced in any

form or by any means, stored or transmitted

electronically in any retrieval system

without written prior permission of the copyright holder.

\section{An original hard copy of this publication has been sent to the following:}

the Zoological Record, Thomson Reuters, Heslington, York, UK

The Natural History Museum, London, UK (BMNH),

the Natural History Museum, Paris, France (MNHN),

the National Museums of Kenya, Nairobi (NMK),

the Royal Museum for Central Africa, Tervuren, Belgium (RMCA),

the Swedish Natural History Museum, Stockholm (NRM),

the Ditsong (Transvaal) National Museum of Natural History, Pretoria, South Africa (TMP),

the Zoological Research Museum Alexander Koenig, Bonn (ZFMK),

the Zoological Museum Amsterdam, Leiden, The Netherlands (ZMA),

the Natural History Museum, Humboldt-University, Berlin (ZMHB),

the Natural History Museum of Denmark, University of Copenhagen (ZMUC),

the Zoological State Collection Munich (ZSM). 


\section{I dedicate my two new genera}

Mountelgonia and Moyencharia to six game rangers who were killed and

to those many people who were injured in an attack on the Institute in the Congo for Conservation of Nature (ICCN) headquarters in Epulu, Democratic Republic of the Congo, on 24th June 2012.

The attack was in retaliation against the ICCN rangers and staff members because of their interfering with illegal poaching and illegal mining in the Okapi Wildlife Reserve. 
$y_{0}+0$

.5. 
Date of Publication: $25^{\text {th }}$ March 2013 (pp.1-82)

\title{
Description of two new genera and ten new species of Metarbelidae (Lepidoptera: Cossoidea) from western, north-central and eastern Africa with notes on habitats and biogeography
}

\author{
INGO LEHMANN \\ University of Bonn, Zoological Research Museum Alexander Koenig, \\ Adenauerallee 160, 53113 Bonn, Germany
}

Friedrich-Ebert-Damm 59, 22047 Hamburg; e-mail: ingo5.lehmann@googlemail.com

\begin{abstract}
Mountelgonia g. nov. and Moyencharia g. nov. are described. The former currently comprising seven species, five of which are described as new: Mountelgonia percivali sp. nov., M. lumbuaensis sp. nov., $M$. thikaensis sp. nov., M. urundiensis sp. nov. and M. abercornensis sp. nov.. Mountelgonia arcifera (Hampson, 1909) and M. pagana (Strand, 1909) have been transferred into the new genus from Metarbela Holland, 1893. The type species of the new genus is M. percivali sp. nov.. Mountelgonia g. nov. is described from Burundi, Rwanda, Kenya, Tanzania and northeast Zambia (eastern Africa) occurring in four distinct phytochoria, namely: i) the Afromontane archipelago-like regional centre of endemism, ii) Somalia-Masai regional centre of endemism, iii) Lake Victoria regional mosaic and iv) Zambezian regional centre of endemism (Afrotropical Region). A butterflylike appearance of the wings among the males of Mountelgonia g. nov. is a character that was not published previously for the family Metarbelidae but for the related family Ratardidae.

The second genus, Moyencharia g. nov., currently comprising six species, five of which are described as new: $M$. mineti sp. nov., $M$. winteri sp. nov., $M$. joeli sp. nov., M. herhausi sp. nov. and M. sommerlattei sp. nov.. The sixth species, M. ochreicosta (Gaede, 1929), has been transferred into the new genus from Teragra Walker, 1855. Teragra basiplaga Gaede, 1929 is treated here as a synonym of Moyencharia ochreicosta (Gaede, 1929). Therefore the subspecific rank of Teragra basiplaga f. fuscoradiata Gaede, 1929 is not adopted here. The species' name "ochreicosta" is given precedence and will be fixed according to the "Principle of the First Reviser." The type species of Moyencharia g. nov. is M. mineti sp. nov.. The new genus is described from the Republic of Guinea, Burkina Faso, Ghana, Nigeria (western Africa); southeastern Chad, northeastern Democratic Republic of the Congo and Republic of South Sudan (north-central Africa) occurring in three phytochoria, namely: i) the Sudanian regional centre of endemism, ii) the Guinea-Congolia/Sudania regional transition zone and iii) Guineo-Congolian regional centre of endemism.

This paper represents the first published records of the family Metarbelidae for the country Burkina Faso. The species of Moyencharia g. nov. from Burkina Faso and Chad represent - together with Kroonia carteri Lehmann, 2010a from Sénégal - the most northern records of the family Metarbelidae on the African mainland (Afrotropical Region).

In addition to the descriptions and illustrations of adult morphology notes on ecology and biogeography are presented.
\end{abstract}

Keywords: Afrotropical Region, Burkina Faso (formerly Upper Volta), butterfly-like appearance, chad, Mountelgonia, Moyencharia, new genera, new species, revision, taxonomy. 


\section{Introduction}

The diversity of the family Metarbelidae came only recently into focus again (Lehmann 1997, 2007, 2008a, b, 2010a, b, 2011, 2012). The Metarbelidae comprise 16 genera and 211 published species (De Prins \& De Prins 2012). However, the number of genera and species are not yet definitive. Ongoing studies by the author suggest that the Metarbelidae comprise at least 25 genera and more than 400 species in the Afrotropical Region. Among the 16 described genera is, for example, the genus Melisomimas Jordan, 1907 based on a misidentified type-species which was in fact a re-description of Melisa grandis Holland, 1893 by Jordan (Fletcher \& Nye 1995). The latter species is a synonym of Melisa diptera (Walker, 1854) that belongs to the family Erebidae. Hence, the genus' name Melisomimas should be replaced since it still includes a second (Metarbelidae?) species recorded from Uganda which is Melisomimas metallica Hampson, 1914.

Recent works using molecular methods placed Metarbelidae as one of the seven families of Cossoidea (Regier et al. 2009; Mutanen et al. 2010; van Nieukerken et al. 2011). Cossoidea was found to be a heterogeneous group not forming a monophylum. It seems that Metarbelidae could be closely related to the Ratardidae which occur in Southeast-Asia and in the northeastern Himalaya. Both families share several morphological features, e.g. having only one strong anal vein on the forewing as well as the deep, 8-shaped ovipositor lobes (Holloway 1986). The butterfly-like appearance of the Ratardidae is also noteworthy. This character is described for the first time for the Metarbelidae in regard to the males of Mountelgonia g. nov..

The present studies of the author suggest that the family Metarbelidae ranges from mainland Africa and Madagascar across the southern Arabian Peninsula (Afrotropical Region) via Nepal and India to Southeast Asia (Lehmann 2008b; De Prins \& De Prins 2012) whilst some alleged New World Indarbela Fletcher, 1922 species belong to the Hypoptinae (Edwards et al. 1998).

Taking into consideration the ongoing deforestation, destruction of natural habitats, rapidly changing anthropogenic environment, and the impossibility of field research in some regions of West Africa and north-central Africa, the historical collections serve as the major source for defining and revising the genera of Metarbelidae. Additionally, they offer a chance to present data on habitats. Lepidoptera species are often associated with certain vegetation types or biotopes (Van Dyck 2011). A particular association of Metarbelidae to legume-dominated forests and woodlands has been emphasized by Lehmann (2008a) based on 14 years of field research in southeast coastal Kenya (Lehmann \& Kioko 2000, 2005). As knowledge about the habitat of new species is often separated from taxonomic papers I will present such information here in regard to the holotype including results based on own field studies in south-central Kenya.

In the frame work of the revision of the family Metarbelidae I will describe two new genera and ten new species in this paper which are based on morphological characters. 


\section{Material and methods}

The 13 species presented here are from the following collections: The Natural History Museum, London (BMNH); Natural History Museum, Paris (MNHN); the private collection Witt, Munich, Germany (MWM); the National Museums of Kenya, Nairobi (NMK); the Swedish Natural History Museum, Stockholm (NRM); Royal Museum for Central Africa, Tervuren, Belgium (RMCA); Zoological Research Museum Alexander Koenig, Bonn (ZFMK); Zoological Museum, University of Copenhagen, Denmark (ZMUC); Natural History Museum, Humboldt-University, Berlin (ZMHB) and Zoologieal State Collection Munich (ZSM). The specimens were photographed and then compared with all described Metarbelidae.

The maceration of the abdomen was done as follows: It was detached and macerated between one to three days in a glass tube containing a cold $10 \%$ solution of potassium hydroxide. After the maceration of the abdomen the genitalia were removed from the abdomen and drawn on a piece of paper in a lateral view, then transferred to distilled water for cleaning and spreading. The preparation of the genitalia was flooded with isopropyl alcohol and remained for two hours before being mounted in Euparal. The genitalia slides were photographed using a digital stereo-microscope (ZEISS-SteREO: Discovery.V20) at ZFMK. The shape of the genitalia, in particular of the valva, might be different in comparison of the lateral view ( $c f$. drawings) with the ventral view ( $c f$. photographs). The reason for this difference is because the drawings were done while the genitalia are not pushed. In contrast, the photographs were taken while the genitalia are below a coverslip that is gently pushed onto them. Specimens of several taxa examined here were studied with Scanning Electron Microscope (SEM, Hitachi S-2460N) at ZFMK.

The terminology for external characters follows Ridgway (1912), Janse (1925), Scoble (1995), Edwards et al. (1998), and for internal features, mainly the genitalia, Sibatani et al. (1954) and Klots (1970). The biogeographical names follow White (1983), Sayer et al. (1992) and Burgess et al. (2004).

\section{Taxonomic review}

\section{Mountelgonia g. nov.}

Type species: Mountelgonia percivali sp. nov.

Diagnosis. The new genus comprises species that are of medium size in comparison to species of other genera in the family Metarbelidae. Mountelgonia possesses typical metarbelid characters (Edwards et al. 1998; Lehmann 2008a, 2012) which are repeated here with some additions in regard to the frontoclypeus, the butterfly-like appearance and the geometric design/wing pattern: Head rugulose, not retracted under the prothorax. The lower frontoclypeus has a pair of pits in a few genera ( $c f$. Lehmann 2011); but in the majority of genera a pair of projections, rather conical in shape (Figures 
11-12), are present or neither pits nor projections occur. Antennae bipectinate in males; bipectinate, unipectinate or filiform in females. Wings broad, very rarely fore- and hindwings are of equal surface (= butterfly-like) as in the males of Mountelgonia g. nov.; a geometric design as defined by Lehmann (2011) is often absent; wing pattern usually present, but often simple, sometimes reticulate or transversely striate on a pale ground-colour. Retinaculum and frenulum very rarely present; chaetosemata and tympanum absent; epiphysis often absent, if present, the epiphysis occurs roughly at middle of foretibia extending to first tarsomere; hindlegs with one or two pairs of tibial spurs; tibia and first tarsomere of hindleg not dilated as in the Cossidae. Accessory cell absent; anterior branch of $R_{4}+R_{5}$ (in forewing) and of $M_{1}$ (in hindwing) in discal cell usually absent (in Cossidae the $M_{1}$ vein stem is present and branches within the discal cells of both wings resulting in an anterior $\mathrm{M}$ and posterior $\mathrm{M}$ vein); $\mathrm{CuP}$ in forewing usually obsolete, very rarely present; one strong anal vein occurs always on the forewing.

Male genitalia: uncus beak-like or wide, tip bifid or bilobed; usually with separate or connected drumstick-like or hand-like or kidney-like or lever-like appendages from uncus (possibly gnathi); socii very small or absent; valvae small, rarely long and elongated, usually rounded or rectangular, sometimes with thorn-like processes, rarely the valvae consist of two lobes, some modification to the sacculus; aedeagus tube-like.

Female genitalia: short, telescopic ovipositor with broad, more or less 8-shaped ovipositor lobes as well as reduced ductus and corpus bursae sensu Holloway (1986); an often expanded membrane between tergite 7 and 8 .

Mountelgonia is defined as a new genus based on i) the naming of the sister taxon and ii) putative morphological apomorphies:

i) It is assumed that the genera Metarbelodes Strand, 1909 and Mountelgonia g. nov. are two monophyletic groups and sister taxa sharing an common ancestor. The genera share male genitalia valvae comprising only one thorn-like process towards the ventral-posterior margin of the valva which is a unique character (apomorphy). The occurrence of this thorn-like process in Metarbelodes and Mountelgonia g. nov. is plesiomorphic within the genera. In Mountelgonia g. nov. the process is only slightly bent and looks like a flat thorn that is shorter than the length of the weakly-sclerotized projection and hence, never extends beyond of the latter. In Metarbelodes the thorn-like process is more developed, that means it resembles a bent thorn that is usually hollow inside and that extends beyond the weakly-sclerotized projection. The occurrence of these two apomorphies suggests the existence of two separated lineages. Two other shared derived characters of the sister taxa are the weakly-sclerotized projection above the thorn-like process as well as an oval shaped emargination in between the process and the projection.

ii) The fore- and hindwing is almost of equal surface, that means butterfly-like, in the males of Mountelgonia g. mov.. The males have a broad forewing that is almost of the same length and width as 
the hindwing. This is a very interesting character since it is similar among the species of the Ratardidae. The butterfly-like appearance of the males of Mountelgonia g. nov. is treated here as an apomorphy for the Metarbelidae (Figures 1A, 3A, 4A, 6A-10A). The females are larger than the males and their forewing is longer than the hindwing, more narrow and elongated (Figures 2A, 5A). The different shape of the wings in both sexes (female not butterfly-like; male butterfly-like) is treated here as a second apomorphy of Mountelgonia g. nov.. In Metarbelodes, the females are 1.5 to $2.5 \times$ larger in wing size than the females of Mountelgonia g. nov. and have elongated and broad forewings with a rounded apex instead of an elongated and narrow forewing. The males of Metarbelodes are smaller than the females and have a broad forewing that is larger than the hindwing. The wings are not of equal surface in both sexes (not butterfly-like).

The combination of characters presented above demand the erection of a new genus. Seven Afrotropical species are currently recognized: Mountelgonia percivali sp. nov., M. lumbuaensis sp. nov., M. thikaensis sp. nov., M. urundiensis sp. nov. and M. abercornensis sp. nov.. Mountelgonia arcifera (Hampson, 1909) and M. pagana (Strand, 1909) have been transferred into the new genus from Metarbela Holland, 1893.

Description. Head: Rough-scaled; long hair-like scales on frontoclypeus; a pair of pits absent, a pair of conical projections present on lower frontoclypeus in both sexes, the two projections are widely separated (Figure 11) and occur close to the upper end of two large pits behind the labial palpi (Figure 12); the labial palpi are almost as long as eye diameter and consist of three segments, the second segment is very long, at least $3 \times$ longer than the basal segment in both sexes; male antennae bipectinate; female antennae rather unipectinate; flagellum and dorsal side of branches scaled (branches appear to be less scaled in females). Thorax: Densely covered with hair-like scales (very fine scales in females) and without a collar ring; with a short crest on metathorax. Epiphyses are absent in both sexes. Hindlegs with one pair of narrow tibial spurs (at least $0.7 \mathrm{~mm}$ long) in both sexes. Forewing upperside without a geometric design; with a simple pattern with all veins darker than the ground colour, except of $\mathrm{CuA}_{2}$ that is always white or ivory yellow in both sexes (Figures 1A-10A). Wing venation similar in both sexes (Figures 1a-9a): in forewing $1 \mathrm{~A}+2 \mathrm{~A}$ forked at base; $\mathrm{CuP}$ obsolete; $\mathrm{CuA}_{2}$ originating from hind margin of posterior cell; $\mathrm{CuA}_{1}, \mathrm{M}_{3}$ and $\mathrm{M}_{2}$ separated and initiating from apical angle of posterior cell; $M_{1}$ initiating from distal margin of median cell; $R_{1}$ initiating from anterior margin of median cell; $R_{2}$ initiating from anterior angle of areole, $R_{3}+R_{4}$ long stalked, initiating from the tip of the areole, $R_{S}$ initiating from posterior angle of areole or is stalked with $R_{3}+R_{4}$ in both sexes; $S c$ more or less parallel to $R_{1}$. In hindwing $C u A_{2}$ initiating from hind margin of posterior cell; $\mathrm{CuA} \mathrm{A}_{1}, \mathrm{M}_{3}$ and $\mathrm{M}_{2}$ initiating from apical angle of posterior cell, separated; $\mathrm{M}_{1}$ and Rs initiating from apical angle of anterior cell, stalked in both sexes; with a bar from $\mathrm{Rs}$ to $\mathrm{Sc}+\mathrm{R}_{1}$ usually; with a small vein in discocellular cell on both forewing and hindwing; cilia long, more than $1.0 \mathrm{~mm}$. 
Retinaculum and frenulum absent. Abdomen: With dense hair-like scales and short abdominal tuft, not longer than one-third of abdomen length.

Male genitalia. Saccus broad and short, $c$. half of weakly-sclerotized projection, usually rounded at tip; uncus large and broad, c. 50-60\% of valva (lateral view), setose (ventral view); rather bifid. Valva ventral-posteriorly with one short and thorn-like appendice, slightly bent at its tip. From half of costal margin a large, setose and weakly-sclerotized projection and a large rounded emargination below (Figures 1b, 3b-4b, 6b-9b). Gnathos covered with many short teeth-like structures at its distal end; gnathal arms not connected by a band basally and not, or only slightly, bent towards uncus. The vinculum and tegumen are fused, forming a firm and very narrow ring. Juxta elongated, with two acuminate lobes and a deep emargination. Phallus simple, tube-like; vesica without cornuti (Figures $10 \mathrm{c}-10 \mathrm{e}, 10 \mathrm{~g})$.

Female postabdominal structure. Papillae anales obliquely 8-shaped or elliptic, covered with short and long setae; segment 8 only setose along its posterior margin, not emarginated dorso-anteriorly. Latero-ventral surface of segment 8 with one rather narrow, half ring-like plate (Figures $2 b, 5 b$ ).

Distribution. The species of Mountelgonia g. nov. are found on highland and/or plateau areas as well as on high plains of eastern Africa, extending their range from Rwanda and Burundi, eastwards via Uganda into Kenya and Tanzania and further south to northern Zambia. Mount Elgon (on the frontier of Uganda and Kenya as well as c. $120 \mathrm{~km}$ northeast of Lake Victoria) is currently the most northern distribution limit and Mbala (formerly Abercorn, northeast Zambia and c. 950km south of Lake Victoria) the most southern limit. The species of the new genus have probably only small distribution ranges in eastern Africa. The new genus is unknown on the Arabian Peninsula and on Madagascar (Figure 31).

Ecology. The species of Mountelgonia g. nov. seem to be forest and woodland species, occurring in areas that belong to submontane or montane zones, respectively. Montane zones are areas above $1.300 \mathrm{~m}$ as defined for tropical Africa by Keay (1959a). The species of the new genus are associated with Afromontane forest types, dense woodlands, wooded grasslands and open shrubbed grasslands, with an average annual rainfall that is adequate moisture such that woody vegetation should form a more or less closed canopy $(c .650 \mathrm{~mm})$ if not disturbed by fire and/or humans. The species of the new genus may be linked to the following vegetation types: "Afromontane rain forest"; "Undifferentiated Afromontane forest"; "Dry transitional montane forest" including patches of "Single-dominant Afromontane forest"; "Zambezian miombo woodland" with open canopies and high-grass or forming an undifferentiated Brachystegia-Isoberlinia woodland with or without Chipya (that is a mosaic of different stages of degradation/re-establishment of evergreen tropical forest that appears as fragments 
of evergreen thicket with a luxurious herbaceous layer); "Somalia-Masai Acacia-Commiphora deciduous bushland and thicket"; "Somalia-Masai edaphic grassland"; "Somalia-Masai riparian forest" and "Somalia-Masai evergreen and semi-evergreen bushland and thicket" sensu White (1983). Different plant communities in the biotopes of the species of Mountelgonia g. nov. share a common feature: woody legumes are dominants or co-dominants with the exception of Afromontane forest.

Etymology. Mountelgonia g. nov. is named for Mount Elgon $(4.321 \mathrm{~m})$ that is a stratovolcano of early Miocene age (25-10 myr B.P.) on the frontier of Kenya and Uganda. It is the type locality of M. percivali sp. nov.. The gender of the new genus is feminine.

\section{A key to the species of Mountelgonia g. nov.}

The key is based exclusively on morphological characters. As for all seven species only one or a few specimens are available, identifications obtained with this key should be cross-checked carefully with the description, distribution and the figures presented in this paper.

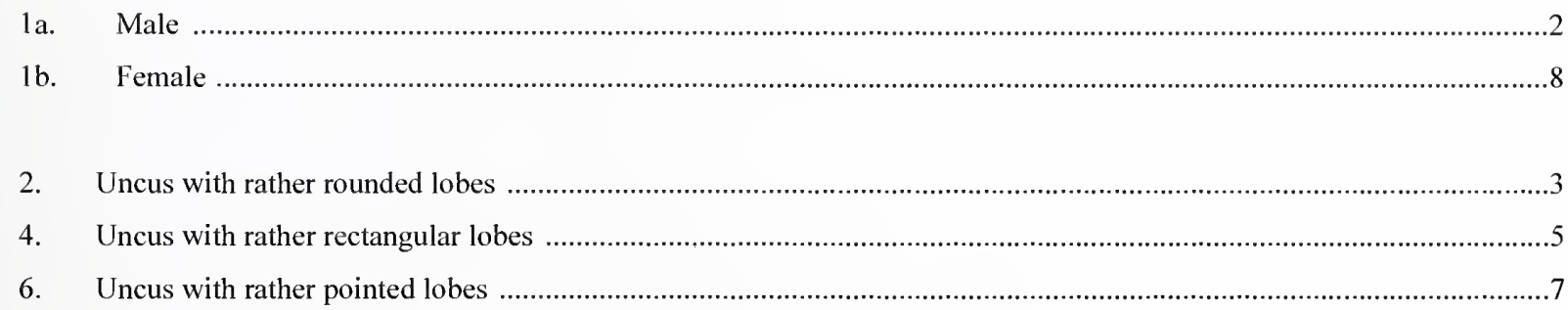

3a. Uncus with an emargination of $30 \%$ of the width of uncus; weakly-sclerotized projection and sacculus densely setose, valvae rectangular and only slightly elongated. ..percivali sp. nov

3b. Uncus with an emargination of $50 \%$ of the width of uncus; weakly-slerotized projection setose, sacculus with few short setae, valvae rectangular and elongated pagana

5a. Uncus with an emargination of $60 \%$ of the width of uncus; weakly-sclerotized projection densely setose, sacculus with no setae, valvae rectangular and broad lumbuaensis sp. nov.

5b. Uncus with an emargination of $50 \%$ of the width of uncus; weakly-slerotized projection short, setose, sacculus with few short setae, valvae rectangular and elongated abercornensis sp. nov.

7a. Uncus with an emargination of $70 \%$ of the width of uncus; weakly-sclerotized projection and sacculus densely setose, valvae rectangular and slightly elongated thikaensis sp. nov.

7b. Uncus densely setose ventrally (long setae), emargination $75 \%$ of the width of uncus; weakly-slerotized projection densely setose, sacculus with few short setae, valvae rectangular, broad 
7c. Uncus densely setose ventrally (short setae), emargination $60 \%$ of the width of uncus, weakly-slerotized projection densely setose, sacculus with few short setae, valvae rectangular, broad. arcifera

8 a.

$8 \mathrm{~b}$.

$8 c$.

9 a.

$9 b$.

Females unknown

abercornensis sp. nov.; lumbuaensis sp. nov.; pagana; thikaensis sp. nov.; urundiensis sp. nov.

Segment 8 forming a sclerotized band ventrally

Segment 8 forming a narrow sclerotized band ventrally with a v-shaped end laterally percivali sp. nov,

Segment 8 forming a narrow sclerotized band ventrally that has a thorn-like, acuminate end laterally

arcifera.

\section{Review of species}

\section{Mountelgonia percivali sp. nov.}

Figures 1A, 2A; 1a, b; 2a, b; 10a.

Material examined. Holotype male, Kenya, Rift Valley Province, Trans-Nzoia District, Mount Elgon National Park, Chepnyalil Cave, 2.500m, 24.January.1992, A. Lobmayer leg., genitalia slide number 27/022012 I. Lehmann (MWM).

Paratypes: one female, Kenya, Rift Valley Province, Trans-Nzoia District, Mount Elgon National Park, Chepnyalil Cave, 2.500m, 24.January.1992, A. Lobmayer leg., genitalia slide number 31/032012 I. Lehmann (MWM); six males, Kenya Colony, Mount Elgon, eastern side, 2.050m, 28.February.1948, A. Holm leg.; same locality and altitude, 05.March.1948, A. Holm leg.; Kenya Colony, Mount Elgon, eastern side, 2.100m, 08.March.1948, A. Holm leg., genitalia slide number 08/072012 I. Lehmann (NRM); Kenya Colony, Kaptagat (today in Rift Valley Province, Uasin Gishu District), 23.December.1948, Walter leg. (NMK); Kenya Colony, Mount Elgon, January.1951, E. Pinhey leg., genitalia slide number 17/062012 I. Lehmann (NMK); Kenya, Eldoret (Rift Valley Province, Uasin Gishu District), February and March.1970, F. Knudsen leg., genitalia slide number 24/032008 I. Lehmann (NMK).

Description. Forewing length in male $10.0 \mathrm{~mm}$ (wingspan $22.0 \mathrm{~mm}$ ), in female $12.5 \mathrm{~mm}$ (wingspan $26.5 \mathrm{~mm}$ ); antenna-wing ratio $0.55: 1$ in male, $0.44: 1$ in female. Head: Yellow ocher, with glinty shine, in between eyes long hair-like scales; eyes olive with small black spots; antennae long, same colour as head; branches of antennae $5.5 \times$ width of shaft in males, $1.5 \times$ in females, covered with creamcoloured scales dorsally; antennal tips with long scales, bending towards apex; labial palpi sepia. Thorax: Patagia and tegulae yellow ocher with glinty shine. Hindfemora, -tibiae and -tarsi yellow ocher with fine hair-like scales and a glinty shine; tibial spurs $0.8 \mathrm{~mm}$ long in male, $0.7 \mathrm{~mm}$ in female. 
Forewing sepia, not glossy; yellow ocher below cell and near base of wing; costal margin sepia and yellow ocher below; veins sepia except of $\mathrm{CuA}_{2}$ that is ivory yellow, same colour extending in a band below cell to base of wing, cell yellow ocher edged sepia; cilia very long, $2.0 \mathrm{~mm}$ in male, $1.2 \mathrm{~mm}$ in female, ivory yellow mixed with sepia. Underside of forewing rough-scaled, ivory yellow, glossy; costal margin and veins sepia in both sexes. Hindwing upperside ivory yellow, glossy; underside as in forewing. Wing venation see Figures 1a and 2a. Abdomen: Mainly ivory yellow with glinty shine.

Male genitalia. Uncus with rounded lobes; gnathos long (slightly longer than basal width of valva); valva more or less rectangular, close to the costa and sacculus the valva carrying short setae, weaklysclerotized projection setose and with a rounded tip, one short thorn-like process with rounded and slightly setose tip; median sector of valva without setae; a deep emargination, extending to almost the centre of the valva, in between the weakly-sclerotized projection and the thorn-like process. Saccus short, finger-shaped, gently rounded caudally. Phallus long, slightly longer than valva, straight, narrowest in middle, bilobed with a cleft.

Variation. The male paratypes do not differ to any major degree in regard to the holotype.

Female postabdominal structure. Papillae anales broad, 8-shaped, densely setose with long setae. Segment 8 without setae except along its posterior margin; dorso-anterior margin of abdominal plate without emargination; segment 8 with one narrow, latero-ventral sclerotized band with a v-shaped end laterally. Posterior apophyses straight, $2.0 \times$ width of anterior apophyses, the latter are slightly shorter than the former, anterior apophyses with bent tips.

Diagnosis. Three characteristics in the male genitalia are important: i) The uncus has got rather rounded lobes with a rounded emargination that is only $30 \%$ of the width of the uncus; ii) the weaklysclerotized projection is densely setose; iii) the sacculus is densely setose. The female has got one outstanding character: Segment 8 has a latero-ventral plate with a v-shaped end. The female of $M$. arcifera is similar but has a latero-ventral plate with a thorn-like acuminate end and the anterior apophyses are almost twice as long as the posterior apophyses while in $M$. percivali sp. nov. the posterior apophyses are slightly longer than the anterior apophyses.

Distribution. M. percivali sp. nov. is known from areas east of the summits of Mount Elgon extending its range via Eldoret to Kaptagat (c. $110 \mathrm{~km}$ southeast of Mount Elgon) in the Western Highlands of Kenya. The new species occurs most probably on the western side of Mount Elgon in Uganda. 
Habitat of type locality. Chepnyalil (altitude $2.419 \mathrm{~m}$, average annual rainfall $1200-1460 \mathrm{~mm}$ ) is located on the northeastern side of Mount Elgon and within Mount Elgon National Park, c. 4km southeast of Masara (Kenya). It is a small, wide cave ( $26 \mathrm{~m}$ deep, $54 \mathrm{~m}$ wide and only $1.5 \mathrm{~m}$ tall) that is associated with a surface water stream and initiated behind a waterfall. It is probably not older than Holocene. The cave was occupied by humans for shelter until about 90 years ago. The walls and ceiling show lots of soot and rock paintings (Lundberg \& McFarlane 2006). Hence, it can be surmised that the forests surrounding the cave were modified by humans. The forests of Mount Elgon belong to the "Afromontane archipelago-like regional centre of endemism" and represent various types of "Afromontane forest" sensu White (1983). Many of the Afromontane tree species have a wide ecological tolerance and a large geographical distribution. Although Afromontane forest types overlap, the drier types are usually shorter and of distinctive floristic composition.

The forests that occur between 2.000 and $3.050 \mathrm{~m}$ on the northeastern side of Mount Elgon were classified by Hamilton (1984) as "Dry Lower Montane Forest" with mainly evergreen sclerophyllous tree species. Hitimana et al. (2004) found that in more or less unlogged forests on the eastern side of Mount Elgon and at an altitude between 2.000 and $2.350 \mathrm{~m}$ (the habitat of three paratypes), forests are up to $25-35 \mathrm{~m}$ tall and comprise dominant species such as Cassipourea malosana (Baker) Alston, Olea capensis L. ssp. welwitschii (Knobl.) Friis \& P.S. Green, Diospyros abyssinica (Hiern) F. White, Croton macrostachys Hochst., Ficus thonningii Blume, Ehretia cymosa Thonn., Podocarpus latifolius (Thunb.) R.Br., Ekebergia capensis Sparrm. and Vernonia auriculifera Hiern..

Ecology based on holotype and paratypes. M. percivali sp. nov. occurs in drier types of "Afromontane forest" sensu White (1983) at high altitudes (up to more than $2.400 \mathrm{~m}$ ).

Etymology. M. percivali sp. nov. is named after the naturalist Arthur Blayney Percival (born in March 1875 , died on the $20^{\text {th }}$ January 1941). He was Kenya's first Game Ranger from May 1901 to early 1923 and one of the founders of the East Africa and Uganda Natural History Society in 1910-11. His Majesty's Deputy Commissioner for the East Africa Protectorate (also known as British East Africa), Sir Frederick Jackson, used much of the data presented by Percival to set up steps towards a legal protection of Game. The efforts of Sir Jackson and Percival resulted in the establishment of the Game Department in 1907 (later called the Kenya Game Department) as a separate unit from the Colonial Service. 


\section{Mountelgonia lumbuaensis sp. nov.}

Figures $3 \mathrm{~A} ; 3 \mathrm{a}, \mathrm{b} ; 10 \mathrm{~b}$.

Material examined. Holotype male, British East Africa (written in German as "Br. O. Afr." on the original label; today Kenya) and hence collected before the year 1920, "Lombwua" (= misspelling of Lumbua or Lumbwa, Rift Valley Province, Nakuru District or Kericho District), no date mentioned on label, Sandb. leg., genitalia slide number 24/062012 I. Lehmann (NRM).

Paratype: one male, same locality and collector, no genitalia dissection done (NRM).

Description. Forewing length in male $10.5 \mathrm{~mm}(10.0 \mathrm{~mm}$ in paratype), wingspan $25.0 \mathrm{~mm}(24.0 \mathrm{~mm}$ in paratype); antenna-wing ratio 0.62:1 (0.64:1 in paratype). Head: warm buff, in between eyes long hairlike scales, sepia towards the eyes; eyes wood brown with large black patches; antennae long, same colour as head; branches of antennae $5 \times$ width of shaft, covered with ivory yellow scales dorsally; antennal tips with long scales, bending towards apex; labial palpi warm buff, laterally sepia. Thorax: Patagia and tegulae densely scaled warm buff mixed with ivory yellow with glinty shine. Hindfemora, -tibiae and -tarsi warm buff with fine hair-like scales and a glinty shine; tibial spurs $1.0 \mathrm{~mm}$ long. Forewing warm buff, not glossy; costal margin sepia; veins sepia except of $\mathrm{CuA}_{2}$ that is pure white, same colour extending in a band below cell to base of wing; cilia long, $1.5 \mathrm{~mm}$, alternating sepia and ivory yellow. Underside of forewing rough-scaled, ivory yellow, not glossy, costal margin and veins sepia. Hindwing upperside ivory yellow, glossy, veins yellow ocher; underside as in forewing. Wing venation see Figure 3a. Abdomen: Mainly warm buff mixed with ivory yellow with glinty shine.

Variation. The male paratype does not differ to any major degree in regard to the holotype.

Male genitalia. Uncus with rather rectangular lobes, densely setose ventrally; gnathos long (longer than basal width of valva); valva more or less rectangular, close to the costa and sacculus the valva carrying no setae, weakly-sclerotized projection densely setose and with a rounded tip, one short thorn-like process with rounded tip that is not setose, median sector without setae, the emargination below the weakly-sclerotized projection is as long as $35 \%$ of the width of valva. Saccus short, broad, less finger-shaped, gently rounded caudally. Phallus long, slightly longer than valva, straight, narrowest in middle, bilobed with a cleft.

Female. Unknown.

Diagnosis. This is one of two large species of Mountelgonia g. nov. compared to the males. Three characters are noteworthy: i) The uncus has got rather rectangular lobes and an emargination that is $60 \%$ of the width of the uncus; ii) the saccus is broad ( $50 \%$ of width of weakly-sclerotized projection); 
iii) the valvae are rectangular and very broad at base that means slightly broader than the length of uncus.

Distribution. M. lumbuaensis sp. nov. is known from the Mau Forest Complex that covers a large area of the southwestern Highlands of Kenya.

Habitat of type locality. The name "Lombwua" appears to be a misspelling of "Lumbua" or "Lumbwa" since only those two locality names were found in old textbooks as well as on several old maps by the author. Charles New (1873) briefly described a locality near a wide stream that is termed "Lumbua" by the natives of the Mau Forest. New marked this locality on his map southwest of Lake Nakuru as well as $c$. $25 \mathrm{~km}$ northwest from "Mau na Erok" (today Mau Narok, altitude $2.829 \mathrm{~m}$, average annual rainfall $1160 \mathrm{~mm}$ ) in the Eastern Mau Forest (today mainly in Nakuru District). It is noteworthy that his map probably represents the only map that shows the native caravan trade routes that lead from the Indian Ocean to the interior, e.g. to the shores of Lake Victoria in the early 1870s. Various old textbooks, and more recently Kerfoot (1964), mention an old name for a locality in the Western Mau Forest termed "Lumbwa" by the Kipsigis (today Kipkelion, altitude $1.950 \mathrm{~m}$, average annual rainfall $1500 \mathrm{~mm}$, Kericho District). This locality used to be a centre of European settlement (since 1915) and is located on the Nyando River, c. $70 \mathrm{~km}$ west from Lake Nakuru and c. $60 \mathrm{~km}$ northwest from Mau Narok. Hence, the type locality might be either in the Western Mau Forest or in the Eastern Mau Forest.

The Mau Forest Complex (altitude 1.800-3.080m; size c. 400.000ha) belongs to White's (1983) "Afromontane archipelago-like regional centre of endemism" and represents the largest single block of closed-canopy forest in Kenya. Forests that constitute the complex comprise 20 forest blocks of various types of "Afromontane forest" sensu White (1983). All forests have been reduced at the expense of the tea industry, flax cultivation (since 1915), farmlands, fire, grasslands and plantations of Pinus patula Schltdl. \& Cham. and Cupressus lusitanica Mill., planted largely since 1958. Today, destroyed natural forest cover decreases usually progressively from about 90 to $50 \%$ towards the upper slopes (e.g. Nkako et al. 2005). Hence, natural forest patches are very rare below $2.300 \mathrm{~m}$. The wetter Western Mau Forest (annual precipitation 1400-2000mm) appears to be mainly an old secondary evergreen to semi-deciduous "Afromontane rain forest" sensu White (1983) dominated in the upper canopy layers by Albizia gummifera (J.F.Gmel.) C.A.Sm., Polyscias ferruginea Harms, P. kikuyuensis Summerh., Fagara macrophylla Oliv. Engl., Diospyros abyssinica (Hiern) F. White, Ekebergia rueppeliana Fresen.A.Rich., Casearia battiscombei R.E.Fries and Allophylus abyssinicus (Hochst.) Radlk. The first two tree species indicate an old secondary forest. The sub-dominant canopy comprises species such as Nuxia congesta R. Br., Catha edulis (Vahl) Forssk., Cassipourea malosana (Baker) Alston, Prunus africana (Hook.f.) Kalkm., Drypetes gerrardii Hutch., Allophylus africanus P. Beauv. and A. macrobotrys Gilg. The lower tree and shrub layers include several species that indicate 
a secondary forest such as Croton macrostachys Hochst., Ehretia cymosa Thonn. and Vernonia auriculifera Hiern. Common riparian tree species comprise Olea hochstetteri Bak., Syzygium guineense (Willd.) DC., Conopharyngia johnstonii Stapf and the tree fern Cyathea manniana Hook. (Kerfoot 1964). Tabernaemontana stapfiana Britten, Neoboutonia macrocalyx Pax and Macaranga kilimandscharica Pax are gregarious primary colonizers in opened up sites.

The Eastern Mau Forest is drier (annual precipitation c. 1000-1200mm) and largely dominated by conifers comprising Juniperus procera Hochst. and Podocarpus latifolius (Thunb.) R.Br. as dominant species locally mixed with Olea capensis L. (Kinyanjui 2011). The Eastern Mau was targeted for excision and settlement, subsequently reduced from 65.921 to 30.620ha in 2001 (Michuki et al. 2008).

Ecology based on holotype and paratype. M. lumbuaensis sp. nov. occurs in various types of wetter and/or drier "Afromontane forest" sensu Whire (1983) at high altitudes (up to $2.830 \mathrm{~m}$ ).

Etymology. M. lumbuaensis sp. nov. is named after the locality Lumbua (Kenya) as mentioned and figured by Charles New (1873).

\section{Mountelgonia arcifera (Hampson. 1909), comb. nov.}

Original combination: Marshalliana arcifera Hampson, 1909

Synonyms: Metarbela arcifera (Hampson, 1909)

In: Hampson (1910), von Dalla Torre \& Strand (1923), Gaede (1929);

Metarbelodes arcifera (Hampson, 1909) in Janse (1925);

Metarbela pallescens Le Cerf, 1914 ( $c f$. note below).

Figures 4A, 5A, 6A; 4a, b; 5a, b; 10c, 11-15.

Note: The type of "Metarbela pallescens Le Cerf, 1914" was not found by the author in museum collections. Nevertheless, it is possible that $M$. pallescens represents a synonym of $M$. arcifera since Gaede (1929, p. 507) described the former species as follows: "Forewing white, at the base somewhat rusty brown. At the inner margin an irregular grey spot. At the inner angle a dark shadow, in front continued in dark streaks. Hindwing dingy white. Male $22 \mathrm{~mm}$. East Africa. This may also be only a faded arcifera." The latter observation is of particular interest. It is also noteworthy that the type locality of $M$. pallescens is Voi (Kenya, c. $275 \mathrm{~km}$ southeast from Stony Athi that is the paratype locality of $M$. arcifera) located in similar habitats as described below. Due to the observation of Gaede, Metarbela pallescens is treated here preliminarily as a synonym of M. arcifera. 
Material examined. Holotype male, Naitolia, British East Africa (today Tanzania, Arusha Region, Monduli District), 26.February.1900, C.S. Betton leg., no genitalia dissection done (BMNH).

Paratype: one male, Athi-ya-Mawe (today Stony Athi, Kenya, Eastern Province, Machakos District), 15.March.1899, C.S. Betton leg., on bottom of label: "1900-10" (indicating that this specimen is most probably from the BMNH, cf. note below), genitalia slide number 19/082012 I. Lehmann (ZFMK).

Note: This specimen is treated here as a paratype of $M$. arcifera and as one of the twelve males collected in Athi-ya-Mawe by C.S. Betton as mentioned by Hampson (1909). Hampson did not expressly exclude those males from the type series ( $c f$. Article 72.4.1 ICZN 1999). Additionally, he described one of the five females collected in Athi-ya-Mawe by C.S. Betton. Hence, the type series of M. arcifera is based on one male from Naitolia (called "type" by Hampson) as well as five females (from which one is described by Hampson) and twelve males. The latter 17 specimens were collected at Athi-ya-Mawe. It is very likely that the male from the ZFMK is originally from the BMNH where I.L. found only seven males (instead of twelve) collected in Athi-ya-Mawe by C.S. Betton between 13.March and 16.March.1899.

Additional specimens: one female, Kenya Colony, southern Masai Reserve (today Rift Valley Province, Narok District), 07.February.1935, Dr B. Benzon leg., genitalia slide number 10/062012 I. Lehmann (ZMUC); one male, Kenya Colony, southern Masai Reserve, 07.February.1935, Dr B. Benzon leg., genitalia slide number 25/022012 1. Lehmann (ZMUC); four males, same locality, same date and collector, no genitalia dissection done (ZMUC); one male, Kenya Colony, northern Masai Reserve, "Tellek" (= misspelling of Talek, Rift Valley Province, Narok District), 10.September.1947, F. W. Brostrup leg., no genitalia dissection done (ZMUC); one male, Kenya Colony, Kajiado (today Rift Valley Province, Kajiado District), October.1951, J. Nagle leg., genitalia slide number 26/042012 I. Lehmann (NMK); one male, same locality, date and collector, genitalia slide number 13/052012 I. Lehmann (NMK); three males, Kenya, Athi River-Kapiti Plains, Eastern Province, Machakos District, Game Ranching and Research Limited, 15.March.1999, I. Lehmann leg., one genitalia slide number 102000 I. Lehmann (deposited in the authors private collection); one male, Kenya, Rift Valley Province, Narok District, Lemek, 15-25.March.2002, Dr. Politzar leg., genitalia slide number 01/042012 I. Lehmann (MWM).

Additional re-description. Forewing length in male paratype $11.0 \mathrm{~mm}$ (wingspan $24.0 \mathrm{~mm}$ ), in female $12.0 \mathrm{~mm}$ (wingspan $26.5 \mathrm{~mm}$ ); antenna-wing ratio in male paratype $0.64: 1$; in female $0.48: 1$. Head: warm buff, in between eyes long and dense hair-like scales, eyes ecru-olive with black patches in both sexes; antennae long in male, ivory yellow, bipectinate, branches of antennae $7 \times$ width of shaft, covered with ivory yellow scales dorsally, antennal tips with long scales, bending towards apex; antennae in female shorter, rather unipectinate, branches of antennae $1.5 \times$ width of shaft, covered with ivory yellow scales dorsally, antennal tips with long scales, not bending towards apex (Figures 13-15); labial palpi warm buff. Thorax: Patagia and tegulae densely covered with hair-like scales, warm buff 
mixed with ivory yellow and pure white with glinty shine. Hindfemora, -tibiae and -tarsi warm buff, tibial spurs $1.1 \mathrm{~mm}$ long in both sexes. Forewing in male and female ivory yellow, costal margin warm buff; all veins warm buff, except $\mathrm{CuA}_{2}$ ivory yellow or pure white; at top of $\mathrm{CuA}_{2}$ a patch of warm buff; cilia long, $1.1 \mathrm{~mm}$ in male, $1.3 \mathrm{~mm}$ in female, ivory yellow. Underside of forewing in both sexes ivory yellow, veins warm buff, rough-scaled, glossy. Hindwing upperside ivory yellow, veins slightly darker, glossy. Underside as in forewing. Wing venation see Figures 4a, 5a. Abdomen: Ivory yellow.

Male genitalia. Uncus with rather pointed lobes, densely setose with short setae ventrally; emargination in between lobes $60 \%$ of the width of uncus; gnathos $1.5 \times$ longer than basal width of valva which is rectangular and broad, costa and sacculus broad with few long setae, weaklysclerotized projection covered with short as well as long setae, thorn-like process short with rather rounded tip and without setae, median sector of valva with scattered setae, emargination below the weakly-sclerotized projection long, $50 \%$ of the width of valva. Saccus short, broad, not finger-like, rounded caudally. Phallus slightly bent, base $3 \times$ broader than distal end, slightly longer than width of valva, bilobed with a cleft.

Female postabdominal structure. Papillae anales broad, 8-shaped, densely setose with long and short setae. Segment 8 with scattered setae as well as with setae along its posterior margin and with one narrow, latero-ventral sclerotized band that has a thorn-like, acuminate end laterally. Dorsoanterior margin of abdominal plate without an emargination. Posterior apophyses straight, with a narrow, hook-like base posteriorly, almost of equal width as anterior apophyses, the latter are slightly longer than the former and without bent tips.

Diagnosis. The male of $M$. arcifera has got three characters that are different compared with the remaining species: i) The lobes of the uncus are densely covered with short setae ventrally;

ii) the saccus is short, broad and not finger-shaped; iii) the median sector of the valva has scattered setae. The female has got two characters that are probably unique for this species: i) Segment 8 forming a narrow sclerotized band latero-ventrally that has a thorn-like, acuminate end laterally; ii) the posterior apophyses have got a narrow and long hook-like base.

Distribution. . arcifera is known from southern Kenya and north-central Tanzania. The Masai Mara National Reserve (southwestern Kenya) is currently the western distribution limit; the Athi RiverKapiti Plains (south-central Kenya) the eastern limit; the area close to Mount Lukenya, the northern limit and Naitolia (north-central Tanzania), the southern limit.

Habitat of type locality. Naitolia (altitude $1.050-1.100 \mathrm{~m}$, average annual rainfall $650-700 \mathrm{~mm}$ ) is a Masai village $c$. $14 \mathrm{~km}$ southeast of Makuyuni. Naitolia (the GPS point in degrees decimals is -3.671 ; 
36.107) belongs to the "Somalia-Masai regional centre of endemism" sensu White (1983). The area is largely covered by bushland which probably has originated after the mass destruction of wildlife, woodland and forest on account of the British Administrations anti-tsetse fly campaign between 1929 and 1935. The bushland comprises species that are usually up to $3 \mathrm{~m}$ tall with taller trees widely scattered, not forming a conspicuous canopy. Dominant species include Acacia mellifera (Vahl) Benth., A. tortilis (Forsk.) Hayne, Balanites aegyptiaca (L.) Del., Commiphora africana (A.Rich.) Engl., Grewia spp., Combretum zeyheri Sond., Terminalia brownii Fresen. and Adansonia digitata L.. The Naitolia floodplains dominate the landscape towards the east with tall grasslands and many trees of $A$. digitata L. at its margins. Numerous drainage courses occur and drain west into the Tarangire River. Hence, riparian woodlands and riverine forests are present, comprising Ficus spp., Acacia sieberiana DC., Kigelia africana (Lam.) Benth., Cordia ovalis R.Br. and Salvadora persica L. (T. Davenport, pers. comm.).

Habitat descriptions for three study sites. Long-term field studies were undertaken by the author between 1989 and 2002 c. $14 \mathrm{~km}$ northwest from Stony Athi (the paratype locality) and c. 3-5km west and southwest from Mount Lukenya $(1.837 \mathrm{~m})$ on a privately owned game ranch created in 1976 (Figures 1-5). All study sites are situated within the "Somalia-Masai regional centre of endemism" sensu White (1983) and on the Athi River-Kapiti Plains in gently rolling terrain at altitudes between 1.580 and $1.610 \mathrm{~m}$ (average annual rainfall between 457 and $740 \mathrm{~mm}$ ). The Athi River-Kapiti Plains are high plains (altitude range c. 1.570-1.650m) which were formed by volcanic Tertiary tuffs and ashes capping on the Kapiti Phonolite. The following three habitats were studied in regard to Lepidoptera and plant species diversity: First, the habitat of one male of $M$. arcifera that comprises largely open Balanites glabra Mildbr. and Acacia drepanolobium Sjöstedt dwarf tree grassland including scattered shrubs and herbs such as Aloe secundiflora Engl., Hibiscus flavifolius Ulbr., Ipomoea jaegeri Pilg., I. longituba Hall., Aerva lanata (L.) Juss. and Schkuhria pinnata (Lam.) Thell.. The grass species Themeda triandra Forssk. and Pennisetum stramineum Peter are dominant (Figures 2-4). Secondly, two males of $M$. arcifera were collected by day sitting on dead wood in a strip of woodland running along a drainage line and dominated by Acacia xanthophloea Benth., A. seyal De Wild. and Cordia crenata Del. with scattered trees of $C$. ovalis $\mathrm{R}$. Br. (Figure 5). Thirdly, about $5 \mathrm{~km}$ to the east from the latter collecting site occur rocky outcrops on the slopes of Mount Lukenya comprising different tree species such as Commiphora schimperi (O.Berg) Engl., Ficus cordata Thunb. and Clausena anisata (Willd.) Benth..

Ecology. M. arcifera occurs in various types of open shrubbed and/or treed grasslands belonging to the "Somalia-Masai Acacia-Commiphora deciduous bushland and thicket" and to "Somalia-Masai edaphic grassland" sensu White (1983) at medium to high elevations (1.050-1.650m). 

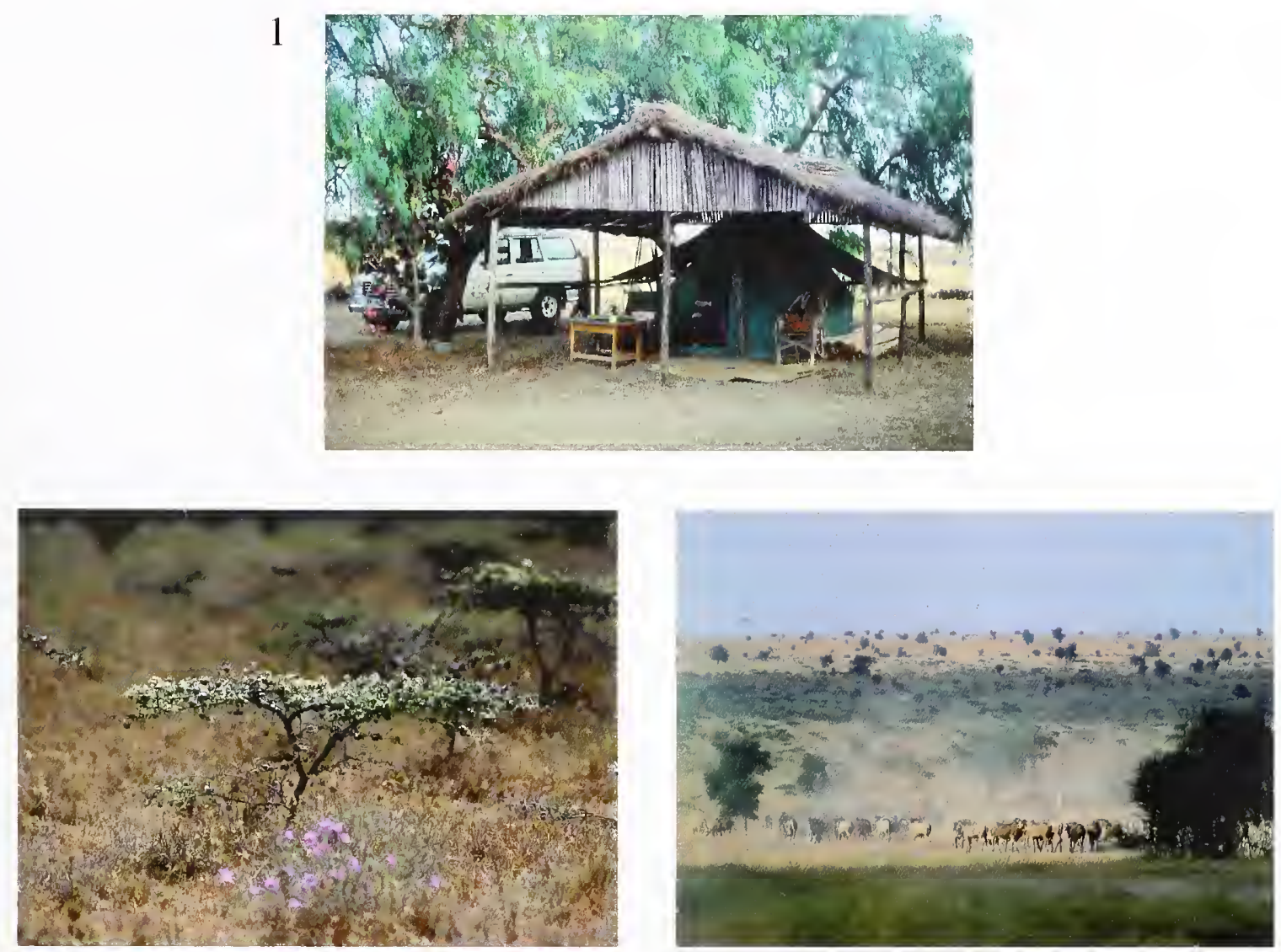

4
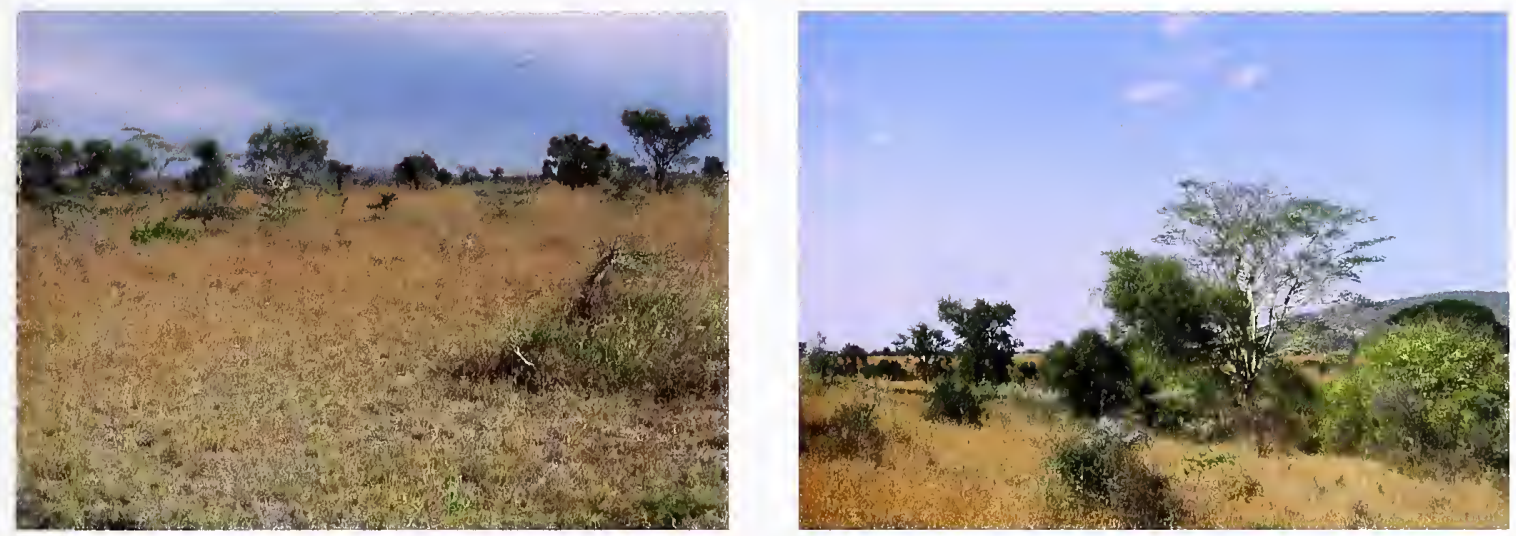

Figures 1-5. 1. The author's research camp in the Athi River-Kapiti Plains, Kenya (January 1995). 2. Dwarf tree grassland with Acacia drepanolobium in flower (background) and lilac flowers of Ipomoea jaegeri in the foreground (February 1998). 3. Themeda triandra grassland with scattered trees of Balanites glabra and Acacia drepanolobium (August 1989). 4. Habitat of Mountelgonia arcifera (Hampson) in Themeda triandra grassland with Acacia xanthophloea and A. drepanolobium (March 1999). 5. Habitat of Mountelgonia arcifera (Hampson) in a strip of woodland running along a drainage line with Acacia xanthophloea, A. seyal, Cordia crenata and C. ovalis (January 2001). 


\section{Mountelgonia abercornensis sp. nov.}

Figures 7A; 6a, b; $10 \mathrm{~d}$.

Material examined. Holotype male, North Rhodesia (today Zambia), Northern Province, Abercorn (today Mbala), August.1969, "I.R.L.C.S." (= International Red Locust Control Service) leg., genitalia slide number 10/082012 I. Lehmann (NMK).

Description. Forewing length in male $10.5 \mathrm{~mm}$ (wingspan $25.0 \mathrm{~mm}$ ); antenna-wing ratio 0.62:1. Head: warm buff, in between eyes long and dense hair-like scales, eyes wood brown with small black spots; antennae long, same colour as head; branches of antennae $7 \times$ width of shaft, covered with warm buff scales dorsally; antennal tips with long scales, bending towards apex; labial palpi warm buff. Thorax: Patagia and tegulae densely scaled warm buff and ivory yellow with glinty shine. Hindfemora, -tibiae and -tarsi warm buff with fine hair-like scales and a glinty shine, one pair of tibial spurs, $1.2 \mathrm{~mm}$ long. Forewing damaged and faded; warm buff, costal margin buckthorn brown; veins probably also buckthorn brown, $\mathrm{CuA}_{2}$ white; cilia long, $0.9 \mathrm{~mm}$, ivory yellow. Underside of forewing faded, roughscaled, warm buff, not glossy, costal margin buckthorn brown. Hindwing upperside warm buff, glossy; underside as in forewing. Wing venation see Figure 6a. Abdomen: Warm buff.

Male genitalia. Uncus with rectangular lobes and with short setae ventrally; emargination in between lobes large, $50 \%$ of the width of uncus; gnathos long ( $1.5 \times$ longer than basal width of valva); valva rectangular, costa with short setae, sacculus with few short setae, weakly-sclerotized projection setose, not elongated, with a short extension at tip, the latter is rounded; thorn-like process short with rounded tip and few setae; median sector of valva with a few short setae; emargination below the weaklysclerotized projection short, $20 \%$ of the width of valva. Saccus short, broad, rounded caudally; juxta peculiar as it has an acuminate process at tip. Phallus long, slightly longer than width of valva, strongly bent basally (lateral view), narrowest in middle, bilobed with a cleft.

Female. Unknown.

Diagnosis. Two characters are outstanding: i) the weakly-sclerotized projection extends slightly at its tip (the tip looks as it has got a tiny process, $c f$. Figure $6 \mathrm{~b}$ ); ii) the juxta has got an acuminate, flag-like process at tip.

Distribution. M. abercornensis sp. nov. is known from Mbala (formerly called Abercorn, northeast Zambia) located on the Central African Plateau. 
Habitat of type locality. Mbala ( $8^{\circ} 50^{\prime} \mathrm{S}, 31^{\circ} 22^{\prime} \mathrm{E}$; altitude $1.676 \mathrm{~m}$, average annual rainfall $1240 \mathrm{~mm}$ ) belongs to the "Zambezian regional centre of endemism" sensu White (1983). Five distinct vegetation types occur: First, miombo woodland including stands with more open canopies resulting in high-grass woodland with Erythrophloeum africanum (Welw.) Harms and Pterocarpus angolensis DC.; secondly, two distinct types of "chipya-woodland" with Parinari curatellifolia Planch., Pterocarpus angolensis DC., Burkea africana Hook.; thirdly, undifferentiated Brachystegia-Isoberlinia woodlands; fourthly, Diplorrynchus scrub-grassland on ironstone soils and soils on the plateau and fifthly, small remnants of tropical moist forest as well as riparian forest. The miombo woodlands cover most of the surroundings of Mbala and were classified by Chidumayo (1997) as "northern wet miombo." The most common canopy dominants include, e.g. Brachystegia spiciformis Benth., B. utilis Burtt Davy \& Hutch., B. floribunda Benth., B. wangermeeana De Wild, B. allenii Burtt Davy \& Hutch., Julbernardia paniculata (Benth.), Isoberlinia angolensis (Welw.) Hoyle \& Brenan, Albizia antunesiana Harms, Pericopsis angolensis (Bak.) van Meeuwen and Marquesia macroura Gilg (Lawton 1963, 1978; Smith \& Trapnell 2002). Chipya is regarded as a mosaic of different stages of degradation/re-establishment of evergreen tropical forest that appears as fragments of evergreen thicket (climbers and lianas present, miombo dominants absent) with a tall and dense grass cover as well as a luxuriant herbaceous component. Chipya comprises species occurring in the GuineoCongolian Region as swamp forest species, e.g. Mitragyna stipulosa (DC.) Kuntze, Syzygium owariense (P.Beauv.) Benth., Uapaca guineensis Müll. Arg. and Xylopia aethiopica (Dunal) A.Rich. as well as moist tropical forest species, e.g. Antiaris toxicaria Lesch., Synsepalum brevipes (Baker) T.D.Penn., Vitex doniana Sweet, Erythrophleum suaveolens (Guill. \& Perr.) Brenan and Afromontane species like Prunus africana (Hook.f.) Kalkm. and the Afromontane near-endemic Ocotea usambarensis Engl..

Ecology based on holotype. M. abercornensis sp. nov. occurs in a woodland mosaic that mainly comprises a species-rich, legume-dominated miombo and distinct types of chipya at high elevations (above $1.600 \mathrm{~m}$ ) representing mainly "Zambezian miombo woodland" sensu White (1983).

Etymology. M. abercornensis sp. nov. is named from the type locality Abercorn (today Mbala, Zambia).

\section{Mountelgonia thikaensis sp. nov.}

Figures $8 \mathrm{~A} ; 7 \mathrm{a}, \mathrm{b} ; 10 \mathrm{e}$.

Material examined. Holotype male, Thika, Kenya Colony (today Kenya, Central Province, Thika District), October.1950, E. Pinhey leg., genitalia slide number 23/022012 I. Lehmann (NMK). 
Descriptiom. Forewing length in male 9.5mm (wingspan 20.0mm); antenna-wing ratio 0.63:1. Head: warm buff, in between eyes long and dense hair-like scales, eyes wood brown with small black spots; antennae long, same colour as head; branches of antennae $5 \times$ width of shaft, covered with ivory yellow scales dorsally; antennal tips with long scales, bending towards apex; labial palpi warm buff, sepia laterally. Thorax: Patagia and tegulae densely scaled warm buff with glinty shine. Hindfemora, -tibiae and -tarsi warm buff with glinty shine, tibial spurs $1.1 \mathrm{~mm}$ long. Forewing warm buff, costal margin and veins with clay colour; $\mathrm{CuA}_{2}$ ivory yellow; cilia long, $1.0 \mathrm{~mm}$, alternating ivory yellow and clay colour. Underside of forewing ivory yellow, rough-scaled, glossy, costal margin clay colour. Hindwing upperside ivory yellow, veins slightly darker, glossy; underside as in forewing. Wing venation see Figure 7a. Abdomen: Warm buff mixed with ivory yellow.

Male genitalia. Uncus with rather pointed lobes and short setae ventrally; emargination in between lobes large, $70 \%$ of the width of uncus; gnathos slightly longer than basal width of valva which is rectangular and slightly elongated, costa without setae, sacculus and weakly-sclerotized projection densely covered with short setae, thorn-like process short with rounded tip and without setae, median sector of valva with some short setae, emargination below the weakly-sclerotized projection long, $40 \%$ of the width of valva. Saccus short, broad, rounded caudally. Phallus bent, as long as width of valva, bilobed with a cleft.

Female. Unknown.

Diagnosis. $M$. thikaensis sp. nov. is similar to $M$. arcifera. The new species comprises four characters that are different compared with the latter species: i) The lobes of the uncus are more pointed; ii) the uncus is ventrally less setose; iii) the valva has an emargination that is not longer than $40 \%$ of the width of valva; iv) the male forewing is more narrow.

Distribution. M. thikaensis sp. nov. is known from Thika, located east of the Eastern Great Rift Valley in the Central Highlands of Kenya.

Habitat of type locality. Thika $\left(1^{\circ} 01^{\prime} \mathrm{S}, 37^{\circ} 04^{\prime} \mathrm{E}\right.$; altitude $1.502 \mathrm{~m}$, average annual rainfall $\left.950 \mathrm{~mm}\right)$ is a town located $c .38 \mathrm{~km}$ northeast of Nairobi, near the confluence of the Thika and Chania rivers. It belongs to the "Somalia-Masai regional centre of endemism" and is also situated at the outskirts of the "Afromontane archipelago-like regional centre of endemism" sensu White (1983). Beentje (1990) mentioned a riverine forest on the Thika River near Thika town that is “... an interesting variant with moist western elements and several endemics." Most riverine forests in the Central Highlands of Kenya represent an impoverished type of Newtonia forest whereas in the Western Highlands of Kenya 
Diospyros-Olea riverine forests are usually found. On the Thika River Newtonia buchananii (Bak.) Gilb. \& Bout. and Ficus scassellatii Pamp. ssp. thikaensis C.C. Berg occur, the latter is known only from localities near Thika. The shrub layer comprises species such as the Kenyan endemic Baphia keniensis Brummit and Indigofera thikaensis Gillett. Most of the natural vegetation around Thika was a "scattered tree grassland with low tree and high grass" in the early 1950s (Edwards \& Bogdan 1951). The dominant species were Combretum spp., Erythrina abyssinica DC., Dombeya burgessiae Gerrard, Terminalia prunioides Laws., Ozoroa insignis Del., Delonix elata (L.) Gamble, Acacia senegal (L.) Willd. and A. mellifera (Vahl) Benth.. This natural vegetation was largely destroyed through agriculture, horticulture and the establishment of sisal as well as coffee plantations (near Thika existed already 17 coffee plantations totaling 716 ha and several sisal plantations totaling 2.000 ha in 1915). The planting of pineapple was begun in 1948, resulting in a large plantation. This is the only pineapple plantation in Kenya and was bought by Del Monte in 1965. It comprises $c$. 5.400ha and hence, covers a large area around Thika today. It is likely that the habitat of the holotype of $M$. thikaensis sp. nov. does no longer exist.

Ecology based on holotype. M. thikaensis sp. nov. occurs in a mosaic of scattered tree grassland and riverine forest. It is noteworthy that Elliot Pinhey often collected along streams and that the Thika riverine forest comprises a species-rich vegetation, including several Kenyan endemics, at high elevations (above $1.500 \mathrm{~m}$ ). The nabitat belongs to the "Somalia-Masai Acacia-Commiphora deciduous bushland and thicket" and "Somalia-Masai riparian forest" sensu White (1983).

Etymology. M. thikaensis sp. nov. is named from the type locality Thika (Kenya).

6. Mountelgonia pagana (Strand, 1909), comb. nov.

Original combination: Metarbela pagana Strand, 1909

Figures 9A; 8a, b; 10f.

Material examined. Holotype male, Northeast-Rwanda (written in German as "Nordost-Ruanda" on the original label), no locality mentioned (neither on the label nor by Strand), August 1907, Wintgens S.G. leg., genitalia slide number 09/122009 I. Lehmann (ZMHB).

Paratype: one male, same locality, date and collector, no genitalia dissection done (ZMHB).

Additional re-description. Forewing length in male $9.0 \mathrm{~mm}$ (wingspan $21.5 \mathrm{~mm}$ ); antenna-wing ratio 0.77:1. Head: warm buff, in between eyes long hair-like scales, eyes wood brown with small black spots; antennae very long, wood brown; branches of antennae $7 \times$ width of shaft, covered with ivory yellow scales dorsally; antennal tips with long scales, bending towards apex; labial palpi warm buff. Thorax: Patagia and tegulae warm buff. Hindfemora, -tibiae and -tarsi warm buff with fine hair-like 
scales and a glinty shine, tibial spurs $1.1 \mathrm{~mm}$ long. Forewing warm buff, not glossy; costal margin as well as veins $\mathrm{CuA}_{2}$ and $1 \mathrm{~A}+2 \mathrm{~A}$ chamois. Cilia long, $1.2 \mathrm{~mm}$ and ivory yellow. Underside rough-scaled, warm buff, glossy. Hindwing upperside ivory yellow, glossy. Cilia and underside as in forewing. Wing venation see Figure 8a. Abdomen: Mainly warm buff.

Variation. The male paratype does not differ to any major degree in regard to the holotype.

Male genitalia. Uncus with rather rounded lobes with few setae ventrally; emargination in between lobes large, $50 \%$ of the width of uncus; gnathos long ( $1.5 \times$ longer than basal width of valva); valva rectangular, costa without setae, sacculus with few short setae, weakly-sclerotized projection setose, elongated and with a rounded tip, one short thorn-like process with rounded tip, not setose, median sector of valva without setae, emargination below the weakly-sclerotized projection $35 \%$ of the width of valva. Saccus short, broad, rounded caudally. Phallus long, slightly shorter than width of valva, straight, narrowest in middle, bilobed with a cleft.

Female. Unknown.

Diagnosis. Three characters are unique: i) The uncus is elongated; ii) the saccus is not finger-shaped but short and broad (20\% of width of weakly-sclerotized projection); iii) the weakly-sclerotized projection and the valva are elongated (Figure 10f).

Distribution. M. pagana is known from northeastern Rwanda, located in the equatorial highlands of east-central Africa along the eastern lip of the Western Great Rift Valley.

Habitat of type locality. Unknown. The northeastern part of Rwanda belongs to the "Lake Victoria regional mosaic" sensu White (1983) that was mainly formed during the middle Pleistocene. Endemism is very low among plants, mammals, birds, reptiles and amphibians (White 1983; Burgess et al. 2004) probably due to the young geological age of this area. Originally, the eastern parts of Rwanda (altitude 1.300-1.600m; average annual rainfall 1000-1400mm) were once covered by drier forests mixed with savanna woodlands. Today the wooded savanna is dominated by trees such as Acacia sieberiana DC., A. senegal (L.)Willd., Lannea humilis (Oliv.) Engler, Albizia petersiana (Bolle) Oliv. and Rhamnus staddo A. Rich., e.g. in the Akagera National Park. Drier forests still occur on hill summits and south of Lake Ihema with dominant trees of Haplocoelum gallaense (Engl.) Radlk., Strychnos usambarensis Gilg, Canthium lactescens Hiern and Nuxia congesta R.Br. (Fischer et al. 2010). The vegetation in the Lake Victoria lowland environment has been significantly modified by human use about 2000 years B.P. (Hamilton et al. 2001). Today more than $80 \%$ of Rwanda bears either anthropogenic vegetation or agriculturally used areas. For example, in the mid-1990s the Tutsi 
had fled Rwanda to Uganda returned to Rwanda, bringing c. 650.000 cattle to graze in Akagera National Park. Hence, $60 \%$ of its area was retracted as protected area to help the refugees (Kelman 2004). It is likely that the habitat of the holotype does no longer exist.

Ecology based on holotype. M. pagana occurs in a mosaic of wooded savanna, farmland and dry forest at elevations above $1.300 \mathrm{~m}$.

\section{Mountelgonia urundiensis sp. nov.}

Figures $10 \mathrm{~A}, 9 \mathrm{a}-9 \mathrm{~b}, 10 \mathrm{~g}$.

Material examined. Holotype male, Urundi (today Burundi), Kitega (today Gitega, Gitega Province, Commune of Gitega), 18.July.1962, Dr M. Fontaine leg., genitalia slide number 20/052012 I. Lehmann (RMCA).

Description. Forewing length in male $9.5 \mathrm{~mm}$ (wingspan $21.0 \mathrm{~mm}$ ); antenna-wing ratio 0.72:1. Head: warm buff, in between eyes long and dense hair-like scales, eyes ecru-olive with a large black patch; antennae very long, pale olive-buff; branches of antennae $6 \times$ width of shaft, covered with pale olivebuff scales dorsally; antennal tips with long scales, strongly bending towards apex; labial palpi warm buff mixed with sepia. Thorax: Patagia and tegulae densely scaled warm buff mixed with sepia and marguerite yellow with glinty shine. Femora, tibiae and tarsi warm buff, hindlegs missing. Forewing warm buff, costal margin with sepia; all veins sepia, except $\mathrm{CuA}_{2}$ ivory yellow; cilia very long, 1.9 $\mathrm{mm}$, warm buff. Underside of forewing warm buff, all veins deep colonial buff, rough-scaled, glossy. Hindwing upperside ivory yellow, veins slightly darker, glossy. Underside as in forewing. Wing venation see Figure 9a. Abdomen: Warm buff.

Male genitalia. Uncus with rather pointed lobes, densely setose with long setae ventrally; emargination in between lobes very large, $75 \%$ of the width of uncus; gnathos slightly longer than basal width of valva; valva rectangular and broad, costa without setae, sacculus with few short setae, weakly-sclerotized projection densely covered with short as well as long setae, thorn-like process short with acuminate tip and without setae, median sector of valva without setae, emargination below the weakly-sclerotized projection long, $35 \%$ of the width of valva. Saccus short, narrow, finger-like, rounded caudally. Phallus slightly longer than width of valva, bilobed with a cleft.

Female. Unknown. 
Diagnosis. M. urundiensis sp. nov. has got one character that is outstanding: The rather pointed lobes of the uncus are densely covered with long setae ventrally (Figure $10 \mathrm{~g}$ ).

Distribution. M. urundiensis sp. nov. is known from Gitega. The town is located on the high Central Plateau of Burundi that covers the whole central part of the country.

Habitat of type locality. Gitega $\left(3^{\circ} 25^{\prime} \mathrm{S}, 29^{\circ} 55^{\prime} \mathrm{E}\right.$; altitude $1.685 \mathrm{~m}$, average annual rainfall $\left.1179 \mathrm{~mm}\right)$ is a large town in the central part of Burundi in an area that is covered by numerous hills divided by large valleys and crisscrossed by a dense network of stream drainages. It belongs to the "Lake Victoria regional mosaic" sensu White (1983). Gitega undergoes a rapid expansion and high demographic pressures contribute to exhaustion of the land for cultivation. The natural vegetation is now seriously degraded. It used to be a meeting place of distinct floras, e.g. of Zambezian and Afromontane species. White (1983) mentioned a "Transitional rain forest" that once occurred in Burundi on the higher western parts of the "Lake Victoria regional mosaic" (as on the hills around Gitega) with Afromontane tree species such as Alangium chinense (Lour.) Harms, Chrysophyllum gorungosanum Engl., Newtonia buchananii (Bak.) Gilb. \& Bout., Strombosia scheffleri Engl., Syzygium guineense (Willd.) DC. and Xymalos monospora (Harv.) Warb.. Only small fragments of this forest type remain (White 1983). About 20km northeast and east of Gitega wooded grasslands occur on altitudes between 1.350 and $1.840 \mathrm{~m}$ with Combretum collinum Fresen., C. molle R. Br., Cussonia arborea Hochst., Entada abyssinica Steud., Hymenocardia acida Tul., Protea madiensis Oliv. and, mainly on hillsides, Parinari curatellifolia Planch. and Pericopsis angolensis (Bak.) van Meeuwen (Masharabu 2011). This species composition is very similar to "Zambezian 'chipya' woodland and wooded grassland" sensu White (1983) that occurs on the transition to lake basin soils on the Central African Plateau around Mbala, northeastern Zambia ( $c f$. habitat description for M. abercornensis sp. nov.). Based on the descriptions of White (1983) and Masharabu (2011) it is very likely that the areas around Gitega were once covered by a mosaic of "Transitional rain forest" on its surrounding hills, riparian forests with Phoenix reclinata Jacq. and papyrus swamps flanked along stream drainages, as well as wooded grasslands with 'chipya' owing their existence to cultivation and/or fire in large valleys.

Ecology based on holotype. $M$. urundiensis sp. nov. occurs in a forest/woodland mosaic with riverine forests at high elevations (above $1.600 \mathrm{~m}$ ) comprising mainly tree species that are linked to the Afromontane and Zambezian regions.

Etymology. M. urundiensis sp. nov. is named for Urundi. This was the country name of Burundi before independence in July 1962. 
$1 \mathrm{~A}$

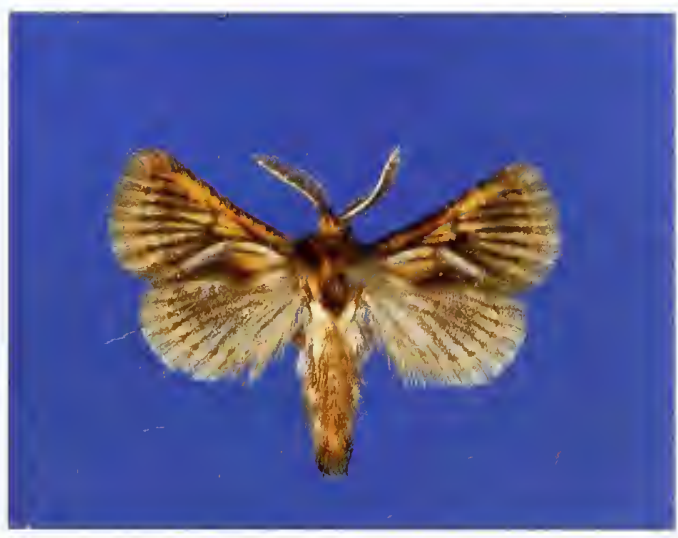

$22 \mathrm{~mm}$

$3 \mathrm{~A}$

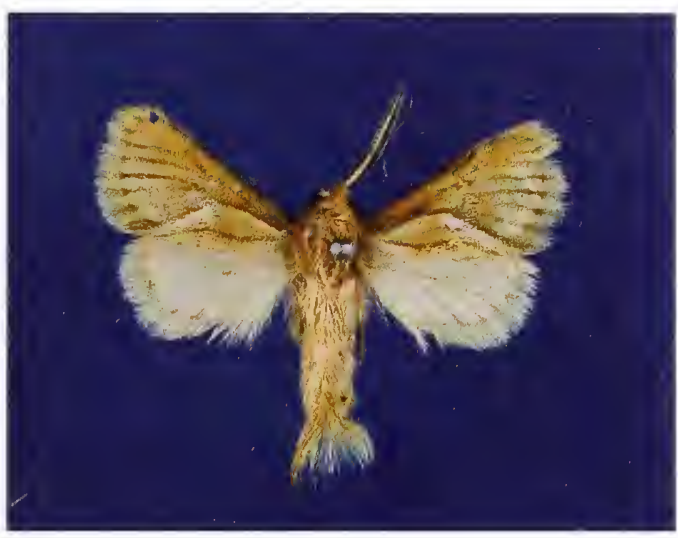

$24 \mathrm{~mm}$

$5 \mathrm{~A}$

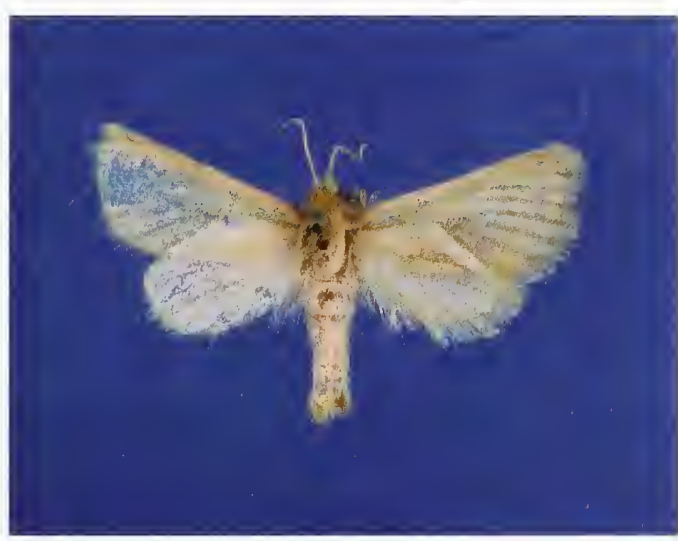

$26 \mathrm{~mm}$

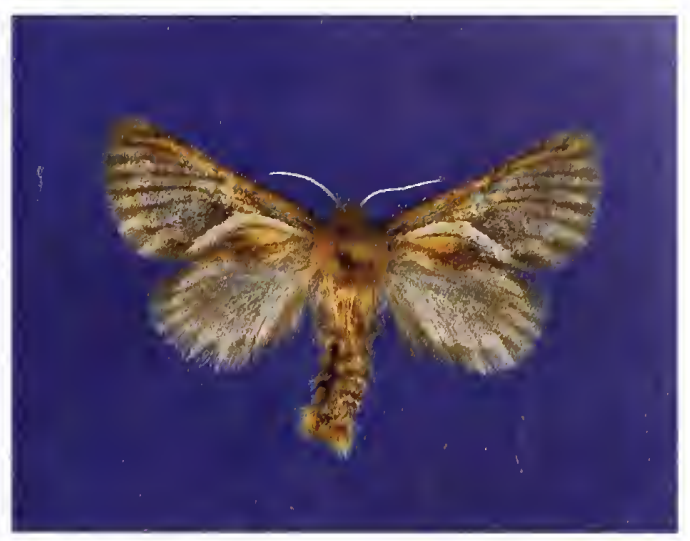

$26,5 \mathrm{~mm}$

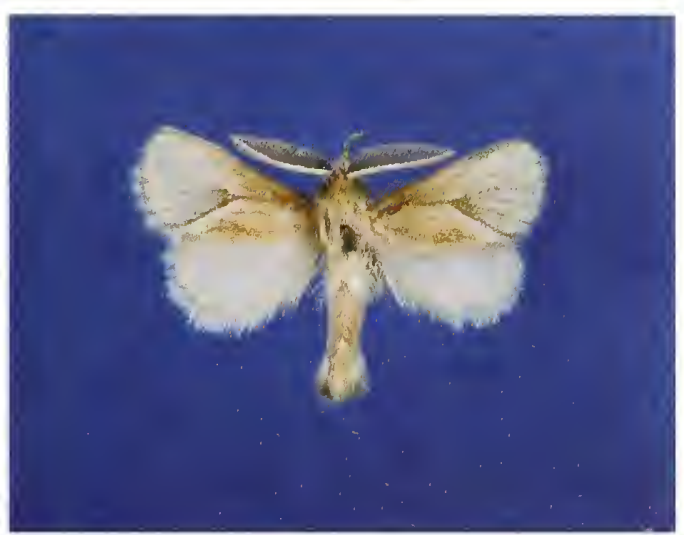

$21 \mathrm{~mm}$

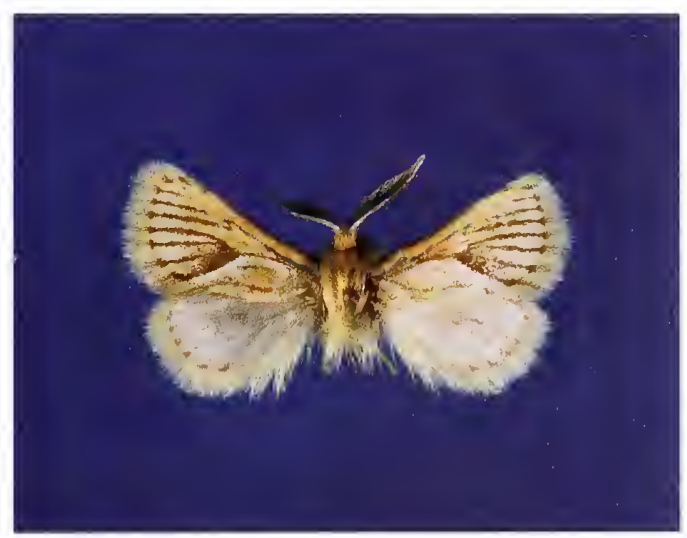

$23 \mathrm{~mm}$

Figure 1A. Mountelgonia percivali sp. nov., male, holotype, Kenya, Rift Valley Province, Mount Elgon National Park.

Figure 2A. Mountelgonia percivali sp. nov., female, paratype, Kenya, Rift Valley Province, Mount Elgon National Park.

Figure 3A. Mountelgonia lumbuaensis sp. nov., male, paratype, Kenya, Rift Valley Province, Lumbua (or Lumbwa).

Figure 4A. Mountelgonia arcifera (Hampson, 1909), male, Kenya, Rift Valley Province, Southern Masai Mara National Reserve.

Figure 5A. Mountelgonia arcifera (Hampson, 1909), female, Kenya, Rift Valley Province, Southern Masai Mara National Reserve.

Figure 6A. Mountelgonia arcifera (Hampson, 1909), male, Kenya, Rift Valley Province, Lemek. 
$7 \mathrm{~A}$

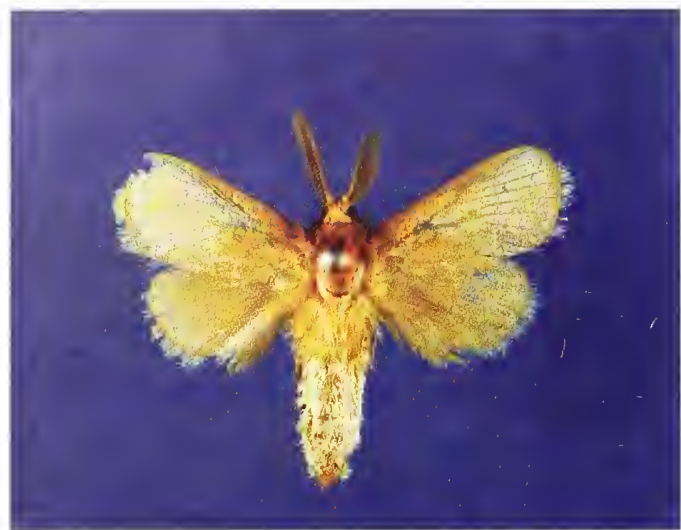

$25 \mathrm{~mm}$

$9 \mathrm{~A}$

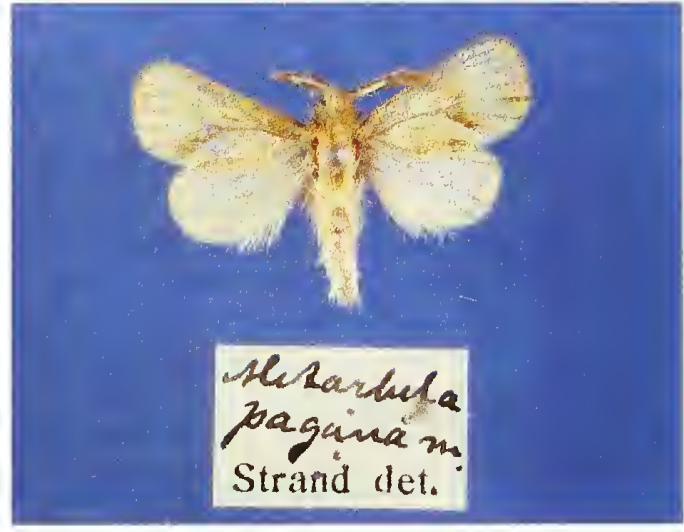

$21,5 \mathrm{~mm}$

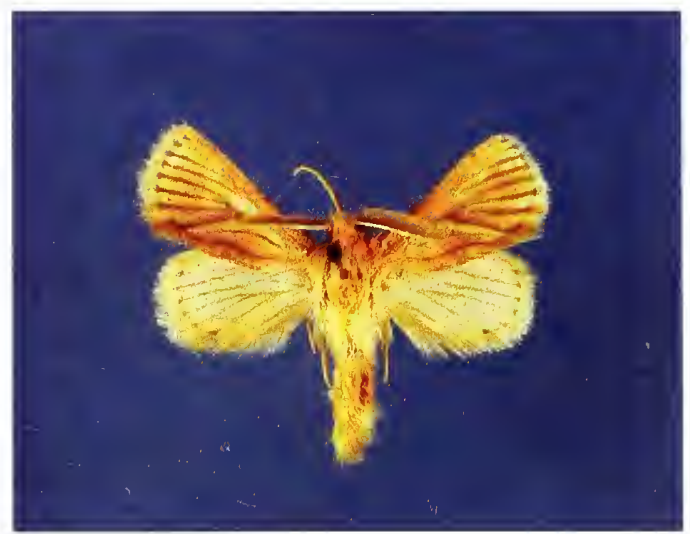

$20 \mathrm{~mm}$

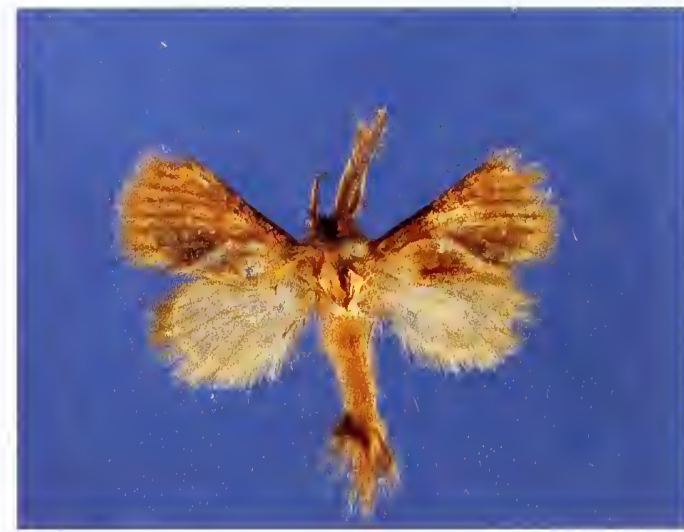

$21 \mathrm{~mm}$

Figure 7A. Mountelgonia abercornensis sp. nov., male, holotype, Zambia, Northern Province, Mbala (formerly Abercorn).

Figure 8A. Mountelgonia thikaensis sp. nov., male, holotype, Kenya, Central Province, Thika.

Figure 9A. Mountelgonia pagana (Strand, 1909), male, holotype, Rwanda, northeastern part of the country.

Figure 10A. Mountelgonia urundiensis sp. nov., male, holotype, Burundi, Gitega Province, Gitega (formerly Kitega). 
$1 a$

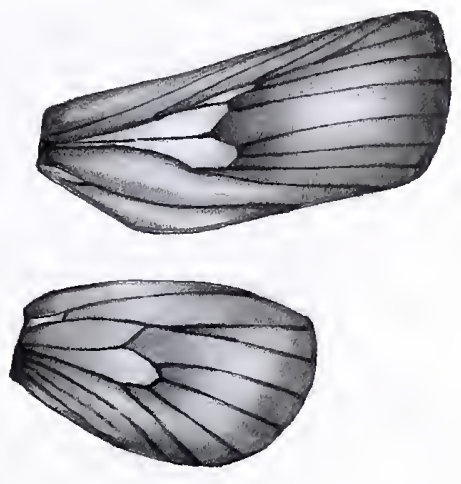

$5 \mathrm{~mm}$

$2 \mathrm{a}$

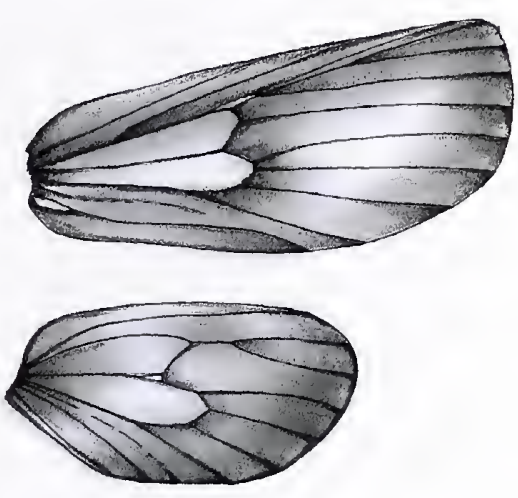

$5 \mathrm{~mm}$

$3 \mathrm{a}$

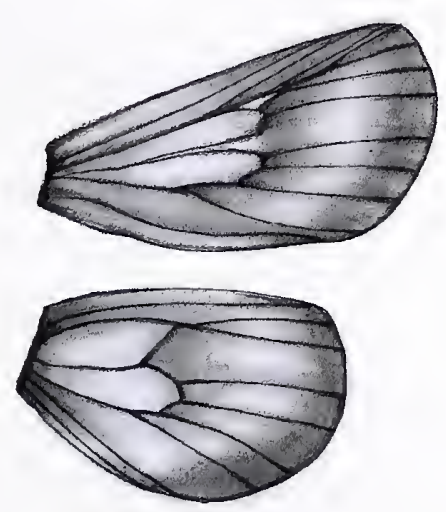

$5 \mathrm{~mm}$

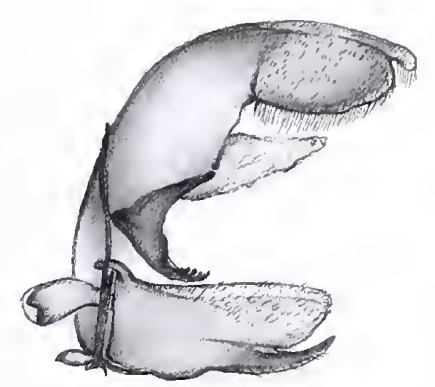

$1 \mathrm{~b}$

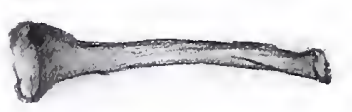

$1 \mathrm{~mm}$

$2 b$
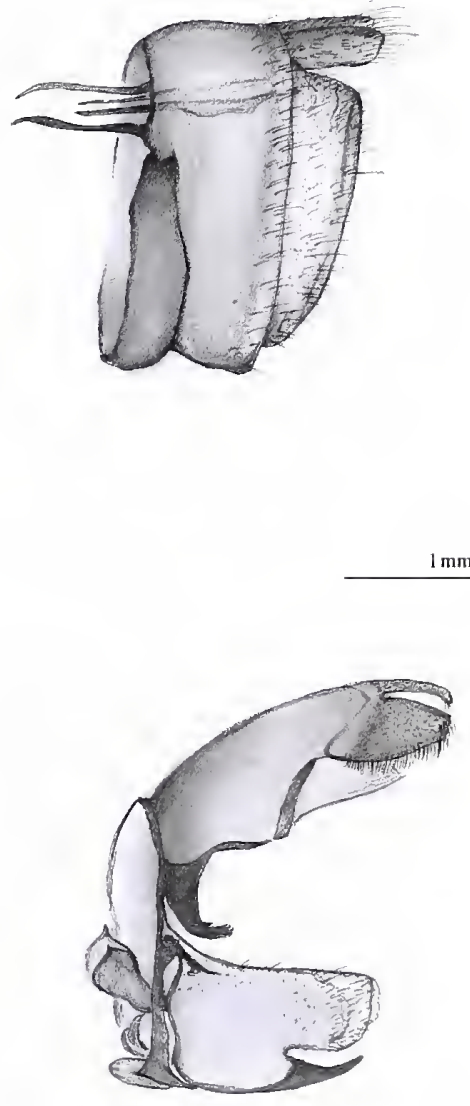

$3 b$

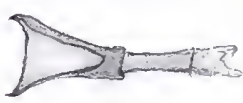

Figure 1a. Wing venation of: Mountelgonia percivali sp. nov., male, holotype. 2a. Mountelgonia percivali sp. nov., female, paratype. 3a. Mountelgonia lumbuaensis sp. nov., male, holotype.

Figure 1b. Genitalia of: Mountelgonia percivali sp. nov., male, holotype. 2b. Mountelgonia percivali sp. nov., female, paratype. 3b. Mountelgonia lumbuaensis sp. nov., male, holotype. 
$4 a$

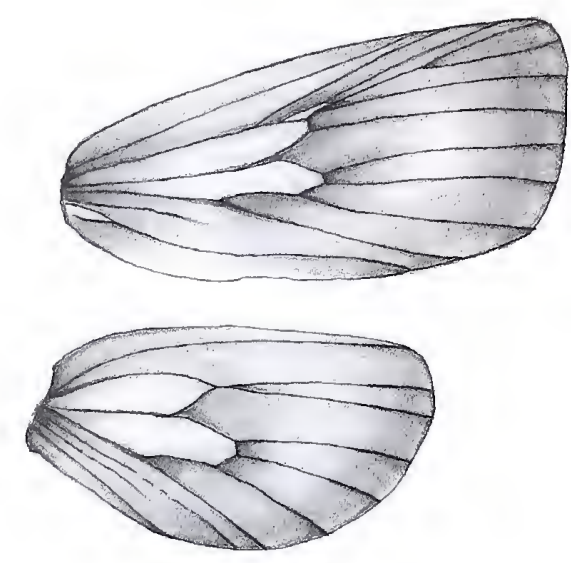

$5 \mathrm{a}$
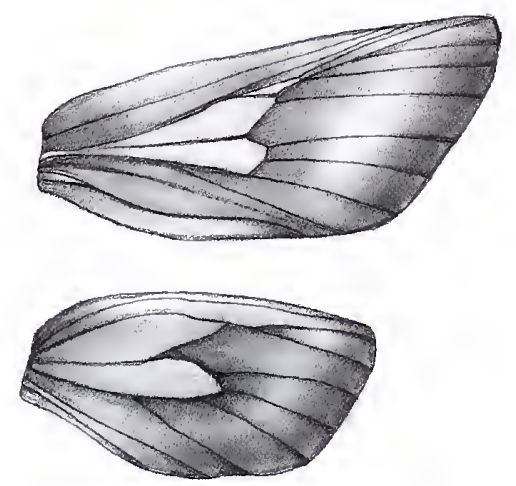

$5 \mathrm{~mm}$

$6 \mathrm{a}$

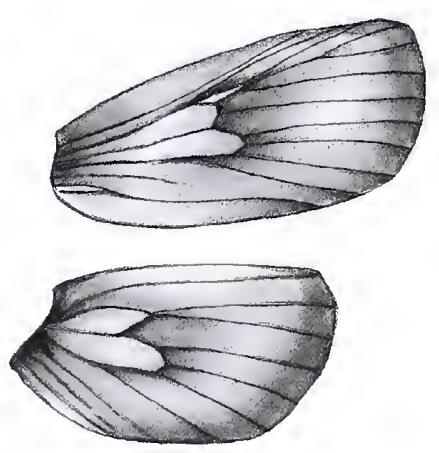

$5 \mathrm{~mm}$

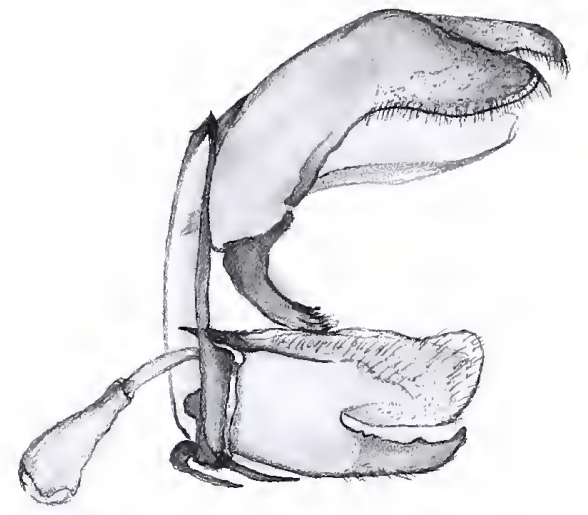

$4 \mathrm{~b}$

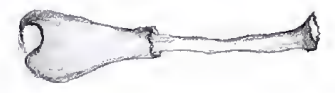

$1 \mathrm{~mm}$

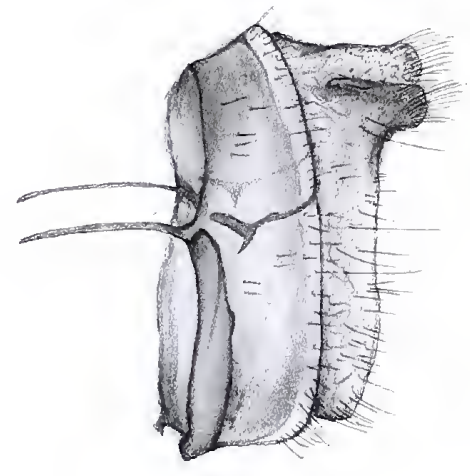

$5 b$

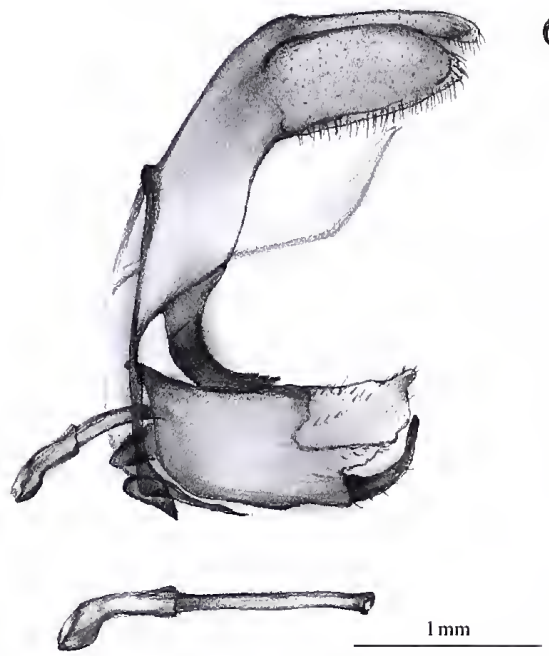

Figure 4a. Wing venation of: Mountelgonia arcifera (Hampson, 1909), male, paratype. 5a. Mountelgonia arcifera (Hampson, 1909), female. 6a. Mountelgonia abercornensis sp. nov., male, holotype.

Figure 4b. Genitalia of: Mountelgonia arcifera (Hampson, 1909), male, paratype. 5b. Mountelgonia arcifera (Hampson, 1909), female. 6b. Mountelgonia abercornensis sp. nov., male, holotype. 
$7 \mathrm{a}$

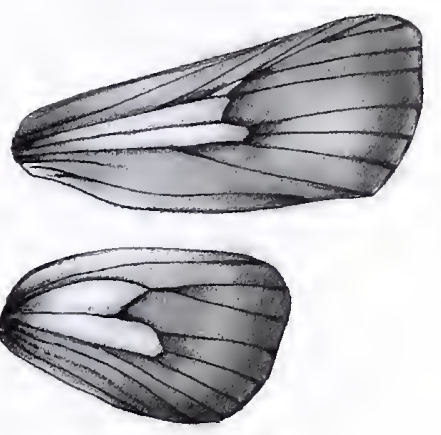

$5 \mathrm{~mm}$

$8 \mathrm{a}$

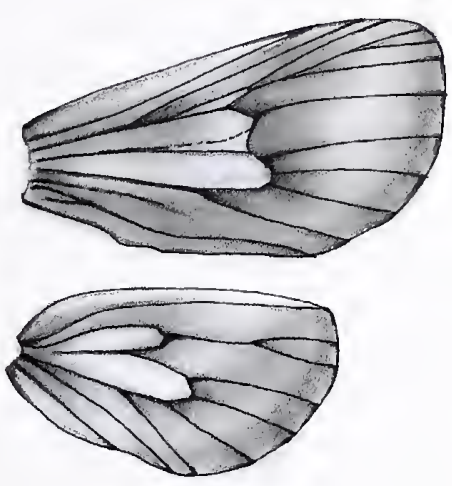

$5 \mathrm{~mm}$

$9 \mathrm{a}$
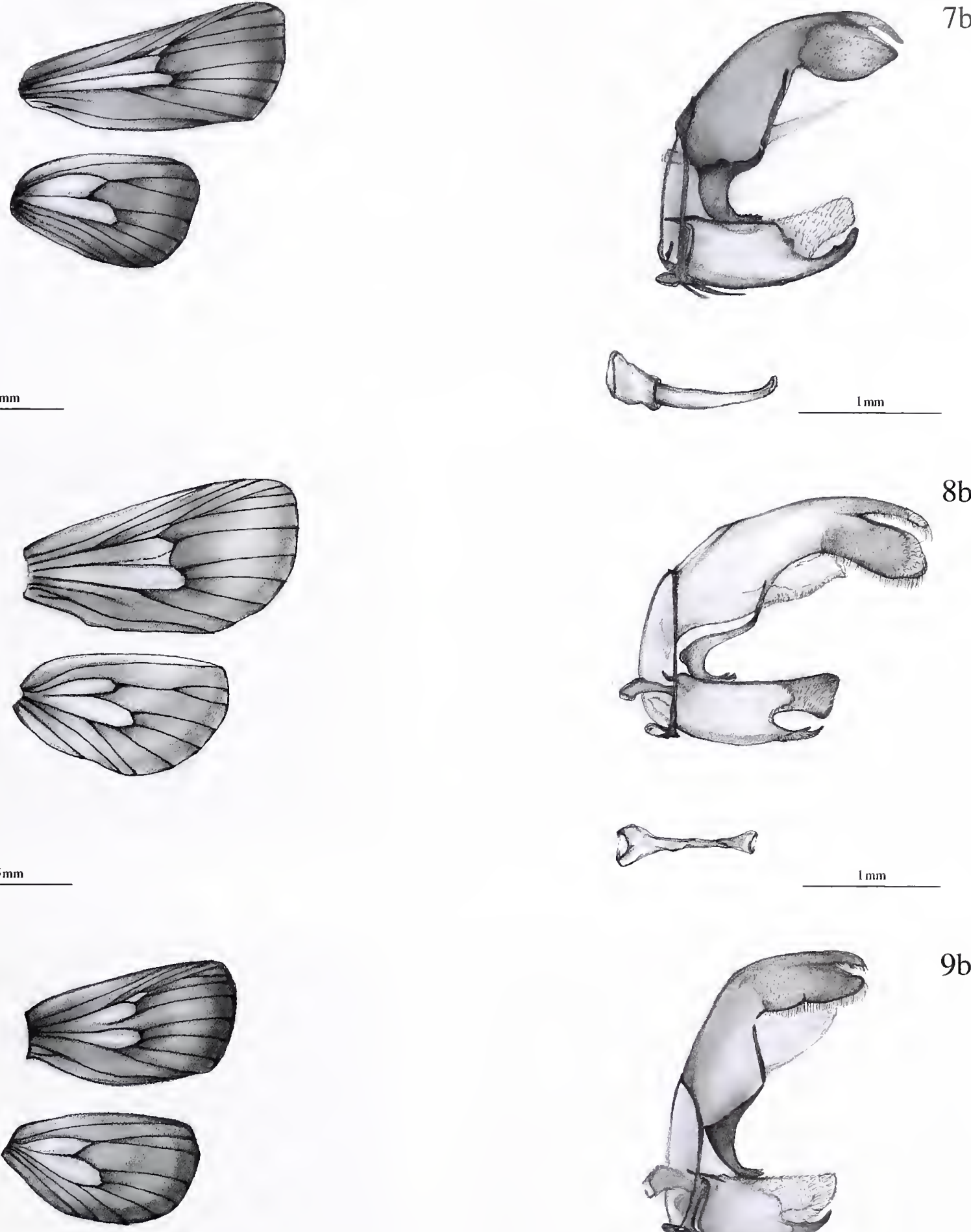

$8 b$

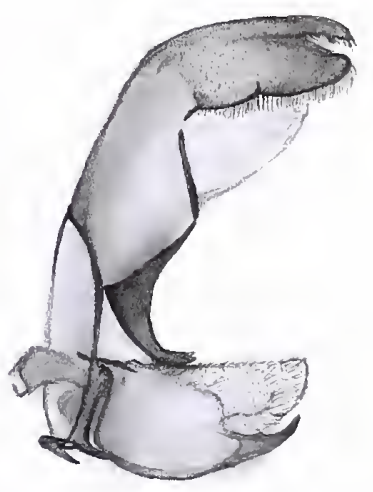

$9 b$

Figure 7a. Wing venation of: Mountelgonia thikaensis sp. nov., male, holotype. 8a. Mountelgonia pagana (Strand, 1909), male, holotype. 9a. Mountelgonia urundiensis sp. nov., male, holotype.

Figure 7b. Genitalia of: Mountelgonia thikaensis sp. nov., male, holotype. 8b. Mountelgonia pagana (Strand, 1909), male, holotype. 9b. Mountelgonia urundiensis sp. nov., male, holotype. 
$10 \mathrm{a}$
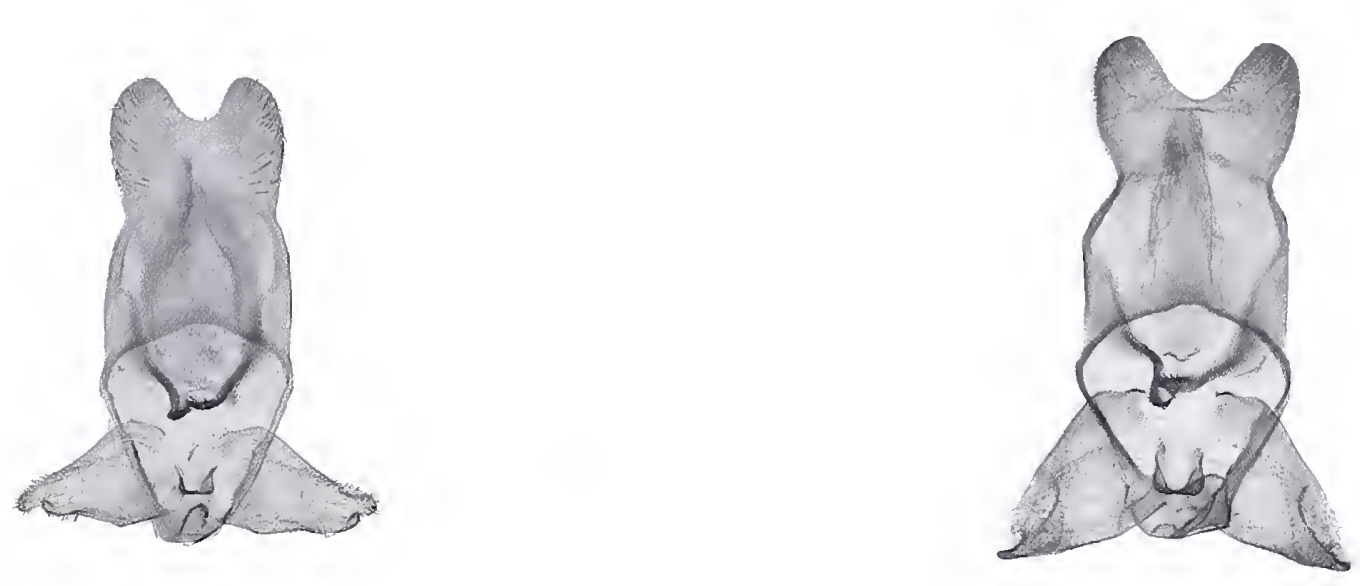

$10 \mathrm{~b}$

$1 \mathrm{~mm}$

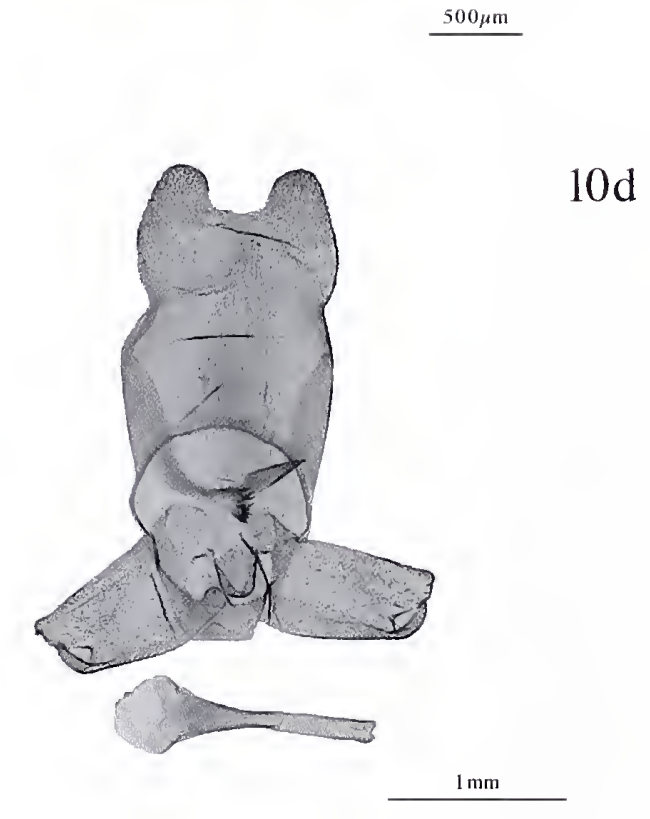

$10 \mathrm{c}$
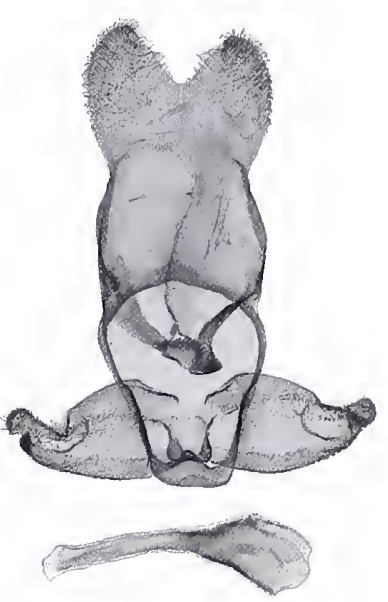

$1 \mathrm{~mm}$

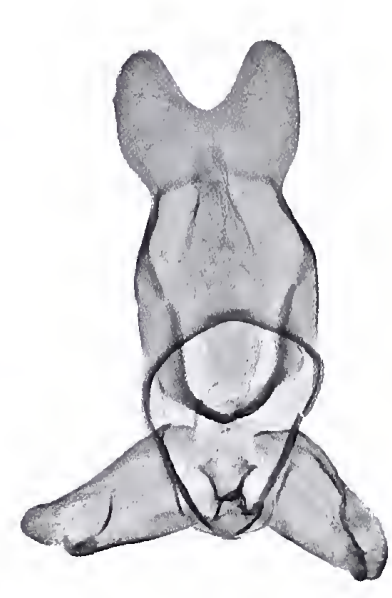

$10 \mathrm{f}$

$10 \mathrm{e}$

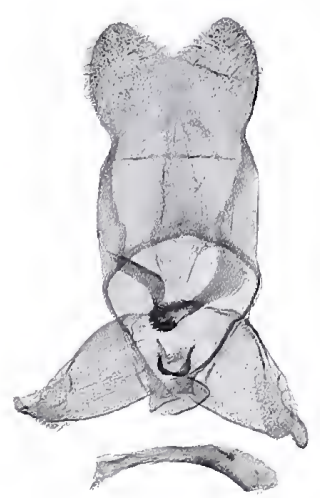

Figure 10a. Genitalia (ventral view) of: Mountelgonia percivali sp. nov., male, holotype. 10b. Mountelgonia lumbuaensis sp. nov., male, holotype. 10c. Mountelgonia arcifera (Hampson, 1909), male, paratype. 10d. Mountelgonia abercornensis sp. nov., male, holotype. 10e. Mountelgonia thikaensis sp. nov., male, holotype. 10f. Mountelgonia pagana (Strand, 1909), male, holotype. 


\section{Taxonomic review}

\section{Moyencharia g. nov.}

Type species: Moyencharia mineti sp. nov.

Diagnosis. The new genus comprises species that are of medium size in regard to the family Metarbelidae. Moyencharia g. nov. possesses typical metarbelid characters (Edwards et al. 1998; Lehmann 2008a, 2012) which were presented above with some additions in context with the new genus Mountelgonia.

Moyencharia g. nov. shares one unique character (apomorphy) with the genera Metarbelodes Strand, 1909 and Mountelgonia g. nov.: The gnathos of the male genitalia of all three genera is covered with short teeth-like structures at its distal end with gnathal arms that are not basally connected by a band. This character is plesiomorphic within all three genera. Nevertheless, there is one difference in this context that suggests the existence of three separated lineages: The distal end of the gnathal arms of Moyencharia g. nov. is more bent upwards towards the uncus while in Metarbelodes and Mountelgonia g. nov. the distal ends are never or only slightly bent towards the uncus ( $c f$. Figures $10 \mathrm{a}-10 \mathrm{f}$ in contrast to $24 \mathrm{a}-24 \mathrm{f}$ ).

It is also noteworthy, that the species of Moyencharia g. nov. do not share the common apomorphies described above for Metarbelodes and Mountelgonia g. nov.. For example, the thorn-like process on the ventral-posterior margin of the valva as well as the weakly-sclerotized projection above this thorn-like process are absent. Additionally, the species of Moyencharia g. nov. have neither pits nor projections on the lower frontoclypeus and two pairs of tibial spurs on hindlegs are present. A geometric design and/or a wing pattern (as defined by Lehmann 2011) with several contrasting colours is present within the genus, e.g. Moyencharia mineti sp. nov., M. winteri sp. nov. and M. sommerlattei sp. nov.. The genera Metarbelodes and Mountelgonia g. nov. have conical projections on the lower frontoclypeus ( $c f$. Figures 11-12 in contrast to 25), only one pair of tibial spurs on hindlegs and no geometric design on their wings. The wing colour is extremely similar among all species within each of the two latter genera. Hence, Moyencharia g. nov. is not closely related to Metarbelodes and Mountelgonia g. nov. although the gnathal arms suggest that the former genus is somehow related to the latter two genera.

Moyencharia is defined as a new genus based on putative morphological apomorphies of the male genitalia (i-ii) and female postabdominal structure (iii):

i) An elongated emargination, which is almost as long as the width of valva, is present in between two short thorn-like structures. The latter occur at the inner (ventral) surface and at the upper half of the valva. 
ii) A plate-like process is attached to the vinculum (or this plate might represent a broader part of the vinculum) and extends into a large emargination that occurs at the outer base of the valva. The plate-like process has no setae, it is separated from the valva and has a rather rectangular shape (it is best visible in a lateral view; $c f$. Figures 16b, 18b, 20b-22b).

iii) The base of the posterior apophysis is broad (at least $3 \times$ broader than the tip of the posterior apophysis) and long (almost as long as half of the posterior apophysis; cf. Figures 17b, 19b, 23b, 24b).

The combination of characters presented above demand the erection of a new genus. Six Afrotropical species are currently recognized: Moyencharia mineti sp. nov., M. joeli sp. nov., M. winteri sp. nov., M. herhausi sp. nov. and M. sommerlattei sp. nov.. Moyencharia ochreicosta (Gaede, 1929) has been transferred into the new genus from Teragra Walker, 1855. Teragra basiplaga Gaede, 1929 is treated here as a synonym of $M$. ochreicosta. Therefore, the subspecific rank of Teragra basiplaga $\mathrm{f}$. fuscoradiata Gaede, 1929 is not adopted here (cf. Figures 23A-27A). The species name "ochreicosta" is given precedence and will be fixed according to the "Principle of the First Reviser" (ICZN 1999).

Description. Head: Rough-scaled with hair-like scales; a pair of pits as well as a pair of projections are absent on the lower frontoclypeus in both sexes, but a large lip-like structure is present (Figure 27). This lip-like structure occurs also in few other genera among the Metarbelidae where it is smaller in size, e.g. in Mountelgonia g. nov. (Figure 12). The two pits behind the labial palpi are remarkably small and flat ( $c f$. Figure 11 in contrast to 26); the labial palpi are as long as eye diameter or a little longer, they consist of three segments of almost equal length but sometimes the central segment is longer than the two other ones in both sexes; male antennae very long (antenna-wing ratio at least $0.50: 1$ ) and bipectinate; female antennae shorter (antenna-wing ratio less than $0.50: 1$ ) and only slightly bipectinate; flagellum and dorsal side of branches densely scaled in both sexes (cf. Figures 28-30). Thorax: Densely covered with hair-like scales; patagia and tegulae usually with a collar ring in both sexes; with a short crest on metathorax. Epiphyses are absent in both sexes. Hindlegs with two pairs of narrow tibial spurs (at least $0.6 \mathrm{~mm}$ long) in both sexes. Forewing upperside with a geometric design and/or with a wing pattern of several contrasting colours; $\mathrm{CuA}_{2}$ at its end with a light spot of white or ivory yellow usually and with some dark as well as light spots in males, $\mathrm{CuA}_{2}$ less distinctly marked in females (cf. Figures 16A-27A). Wing venation similar in both sexes (cf. Figures 16a-23a): In forewing $1 \mathrm{~A}+2 \mathrm{~A}$ forked at base; $\mathrm{CuP}$ obsolete; $\mathrm{CuA}_{2}$ originating from hind margin of posterior cell; $\mathrm{CuA}_{1}, \mathrm{M}_{3}$ and $\mathrm{M}_{2}$ separated and initiating from apical angle of posterior cell; $\mathrm{M}_{1}$ initiating from distal margin of median cell; $R_{1}$ initiating from anterior margin of median cell; $R_{2}$ originates free from the anterior tip of the areole, $R_{3}+R_{4}+R_{5}$ long stalked or $R_{5}$ originates from the same point as $R_{3}+R_{4}$, the latter originate from the posterior tip of the areole in both sexes; Sc more or less parallel to $\mathrm{R}_{1}$. In hindwing $\mathrm{CuA}_{2}$ initiating from hind margin of posterior cell; $\mathrm{CuA}, \mathrm{M}_{3}$ and $\mathrm{M}_{2}$ initiating from apical angle of posterior cell, separated, or $\mathrm{CuA}_{1}$ and $\mathrm{M}_{3}$ from the same point; $\mathrm{M}_{1}$ and Rs initiating from 
apical angle of anterior cell, stalked in both sexes; usually with a bar from $\mathrm{Rs}$ to $\mathrm{Sc}+\mathrm{R}_{1}$; with a small vein in discocellular cell on both forewing and hindwing; cilia long, more than $1.0 \mathrm{~mm}$. Retinaculum and frenulum absent. Abdomen: With dense hair-like scales and short abdominal tuft, not longer than one-third of abdomen length.

Male genitalia. Saccus variable, sometimes broad and rounded caudally, or broad at base but narrow towards tip, rather finger-shaped, or very small or absent; a structure extends sometimes from the saccus posteriorly towards or below the sacculus, it can be very long, almost as long as half of width of valva and might be a part of the saccus; uncus large and broad, c. $70-90 \%$ of the size of the valva (lateral view), densely setose on ventral surface; bilobed. Valva on the ventral surface and on the upper half with two thorn-like and bent appendices, tips acuminate. In between of the two thorn-like appendices there is an elongated, narrow emargination that is almost as long as the width of valva ( $c f$. Figures 16b, 18b, 20b-22b, 24a, 24c-24f). A skin-like structure (weakly-sclerotized with many setae) extends on the ventral surface from the costa towards the median sector of the valva but covers only the inner half of the emargination. Gnathos with many short teeth-like structures at its distal end; gnathal arms not basally connected by a band and strongly bent towards uncus. The vinculum and tegumen are fused, forming a firm and very narrow ring. Juxta oval-shaped, without acuminate lobes, a deep emargination is absent ( $c f$. Figures $24 \mathrm{c}-24 \mathrm{f}$ ). Phallus simple, tube-like, sometimes strongly bent and/or with two tiny acuminate appendices; vesica without cornuti.

Female postabdominal structure. Papillae anales obliquely 8-shaped and elliptic or beak-like (lateral view), covered with short and long setae; segment 8 usually setose along its posterior margin but sometimes with only few scattered setae; rarely, few scattered setae occur on the whole segment 8 (Figure 23b); it is not emarginated dorso-anteriorly. The base of the posterior apophysis is very broad (at least $3 \times$ broader than the tip of the posterior apophysis) and long ( $c$. half of the posterior apophysis; $c f$. Figures 17b, 19b, 23b, 24b).

Distribution. The species of Moyencharia g. nov. occur in western and north-central Africa, namely from the Republic of Guinea via Burkina Faso (formerly Upper Volta), Ghana and Nigeria, eastwards via southern Chad into the Republic of South Sudan and further south to the northeastern Democratic Republic of the Congo (DRC). Bobo Dioulasso (southwestern Burkina Faso) is currently the most northern distribution limit and Moto (northeastern DRC) the most southern limit; the Republic of Guinea the most western limit and Tambura (Republic of South Sudan) the most northeastern limit.

The species of Moyencharia g. nov. from Burkina Faso represent the first published records of the family Metarbelidae from the country Burkina Faso. The species of the new genus do not occur south of Lower Guinea and Congolia subdivisions of the Guineo-Congolian Region as defined by White (1979) and include various of the most northern species records among the family Metarbelidae 
on the African mainland (Afrotropical Region). The species of Moyencharia g. nov. are currently the only ones among the Metarbelidae which extend from the Guineo-Congolian Region northwards into the Sudanian Region. The new genus is unknown on the Arabian Peninsula and on Madagascar (Figure 32).

Ecology. The species of Moyencharia g. nov. are forest and woodland species occurring in tropical lowland areas (altitude below $1.300 \mathrm{~m}$ ) with an average annual rainfall of at least $900 \mathrm{~mm}$. The species of the new genus are associated with lowland tropical rain forests as well as with a mosaic that contains various wetter and drier types of forests, riparian forests, woodlands, open wooded grasslands and open shrubbed grasslands. Woody legumes are not always dominant, but species of the genera, e.g. Anogeissus, Khaya and Prosopis. Sometimes pockets of forest remnants occur in wooded grasslands that might represent relicts of a wetter climate during the interglacial periods (White 2001).

Many of the wooded grasslands or shrubbed grasslands within the distribution range of Moyencharia g. nov. are determined by recurrent fires (e.g. Richards 1959, 1998) and were termed by Keay (1959b) "Derived Savanna" which arise "... from moist forest by degradation." Hence, the species of the new genus might be potential indicators for a former continuous rain forest, moist and/or dry forest or woodland cover. Two examples are Moyencharia ochreicosta (Gaede, 1929) and $M$. winteri sp. nov. that extend from the rain forests of the "Guineo-Congolian regional centre of endemism" into the "Sudanian regional centre of endemism" sensu White (1983; Figure 32).

According to the present data, the species of Moyencharia $\mathbf{g}$. nov. appear to be mainly linked to the following vegetation types of the Sudanian Region, Guinea-Congolia/Sudania Transition Zone and Guineo-Congolian Region (from north to south): "Sudanian swamp forest and riparian forest" that includes a number of tree species also occurring in the Guineo-Congolian Region; "Sudanian dry forest" that is dominated by woody legumes, mainly by two evergreen caesalpiniaceous tree species; "Sudanian transition woodland" that also comprises tree species that are not fire-tolerant and hence, includes places where the forest invades savanna; "Sudanian woodland" and "Sudanian grassland" including several subtypes; "Drier peripheral semi-evergreen Guineo-Congolian rain forest and similar forest in the transition zones" and "Mixed moist semi-evergreen Guineo-Congolian rain forest" sensu White (1983). The latter two comprise various types of (rain) forest which used to be widespread, e.g. in the distribution ranges of Moyencharia ochreicosta, $M$. joeli sp. nov. and $M$. winteri sp. nov., but they have been extensively destroyed, e.g. by fire, cultivation or mining.

It is likely that the species of Moyencharia g. nov. originated in the lowland tropical rain forests of the Guineo-Congolian Region and hence, they might represent relicts of a wetter climate during the interglacial periods in the Sudanian Region. 
Etymology. Moyencharia g. nov. is named for the Region du Moyen-Chari in south-central Chad. It is the type locality of $M$. mineti sp. nov. ( $c f$. habitat description below). The Moyen-Chari was selected for the new genus name since it represents an area with one of the most northern records of the family Metarbelidae on the African mainland. The gender of the new genus is feminine.

Bionomics: The author assumes that the caterpillars of all species of Metarbelidae, including the species of Mountelgonia g. nov. and Moyencharia g. nov., feed on the bark and/or in the wood of (mainly legume) tree species, perhaps also in roots of small (mainly legume) woody plants. However, the biology of all Metarbelidae species is unknown at present. The little knowledge that exists about the biology was presented by Lehmann (2008a) for few species that belong to other genera.

\section{A key to the species of Moyencharia g. nov.}

The key is based exclusively on morphological characters. As for all six species only one or a few specimens are available, identifications obtained with this key should be cross-checked carefully with the description, distribution and the figures presented in this paper.

1a. Male

2. Uncus with rather narrow elongated lobes and short extension of saccus posteriorly .................................................

4. Uncus with rather broad rounded lobes and without extension of saccus posteriorly .................................................5

6. Uncus with rather broad rounded lobes and rather long extension of saccus posteriorly ...............................................

3. Saccus extends posteriorly only to below base of sacculus, uncus densely setose (long setae) ventrally

mineti sp. nov

5. Saccus does not extend posteriorly to below sacculus, uncus densely setose (short setae) ventrally

sommerlattei sp. nov.

7a. Saccus extends posteriorly to below sacculus and to $c .35 \%$ of width of valva, uncus densely setose ventrally with long setae (prickly appearance) joeli $\mathrm{sp}$. nov.

7b. Saccus extends posteriorly to below sacculus and to $c$. $40 \%$ of width of valva, uncus densely setose ventrally with short setae (no prickly appearance) herhausi sp. nov.

7c. Saccus anteriorly absent, but extends posteriorly to below sacculus and to $c .15 \%$ of width of valva, uncus densely setose ventrally with short setae 
8b. joeli sp. nov,; herhausi sp. nov.; sommerlattei sp. nov.

8c. Base of posterior apophysis broad and long.....

Base of posterior apophysis $3 \times$ broader than tip of posterior apophysis, base long but less than half of length of posterior apophysis winteri sp. nov

9b. Base of posterior apophysis $5 \times$ broader than tip of posterior apophysis, base long but less than half

of length of posterior apophysis mineti sp. nov.

9c. Base of posterior apophysis $7 \times$ broader than tip of posterior apophysis, base long and $c$. half of length of posterior apophysis ochreicosta.

\section{Review of species}

\section{Moyencharia mineti sp. nov.}

Figures 16A, 17A; 16a, b; 17a, b; 24a, b; 25-30.

Material examined. Holotype male, Chad, Region du Moyen-Chari, Canton") de Gondey, Makoga, 04.-12.May.1965, chassé a la lumiére (= at light), J.M. Fonteneau leg., genitalia slide number 22/012012 I. Lehmann (MNHN).

Paratype: one female, Chad, Region du Moyen-Chari, Canton de Gondey, Makoga, 04.-12.May.1965, J.M. Fonteneau leg., on second label: "Muséum Paris don de H. Ungemach", genitalia slide number 06/012012 I. Lehmann (MNHN).

Description. Forewing length in male $9.0 \mathrm{~mm}$ (wingspan $20.0 \mathrm{~mm}$ ), in female $14.0 \mathrm{~mm}$ (wingspan $32.0 \mathrm{~mm}$ ); antenna-wing ratio 0.61:1 in male, 0.29:1 in female. Head: Cream-buff mixed with sepia and hair-like scales with white or ivory yellow tips, glossy; in between eyes long hair-like scales; eyes ecru-olive with black patches; antennae bipectinate and long in male, bipectinate but short in female (Figures 28-30), same colour as head; branches of antennae $4.5 \times$ width of shaft in males, $1.5 \times$ in females, branches and shaft covered with ivory yellow scales dorsally in both sexes; antennal tips with longer scales, bending towards apex; labial palpi cream-buff. Thorax: Patagia with white collar ring in both sexes; tegulae cream-buff with scales that have a sepia coloured tip and pure white scales forming a second collar ring in male; tegulae in female yellow ocher with short scales that have a sepia

1) During the colonial era, the French superimposed a territorially based administration over pre-colonial Sara (who live mainly in the Moyen-Chari) and their social and political institutions. On the local level, this took the form of the "canton" or county. The "canton" was headed by a chief named by the central government, who in turn named "village chiefs." 
coloured tip and longer scales that are pale drab-grey; patagia and tegulae with glinty shine in both sexes. Hindfemora, -tibiae and -tarsi cream-buff mixed with ivory yellow, with fine hair-like scales and a glinty shine; tibial spurs $0.7 \mathrm{~mm}$ long in male, $0.9 \mathrm{~mm}$ in female. Forewing warm buff, not glossy; both sexes have a slightly different wing pattern: female with a large yellow ocher patch in the centre of the forewing (absent in male); a broad cinnamon-brown subterminal band from apex to dorsum that is edged black and white towards termen (reduced in male from $M_{1}$ to apex); the blackish patch below the centre of the discocellular cell and below $1 \mathrm{~A}+2 \mathrm{~A}$ is larger than in the male; the cinnamon-brown striae in the outer half of the forewing are numerous if compared with the male; at top of $\mathrm{CuA}_{2}$ occurs a small pure white patch in both sexes; at the centre of $\mathrm{M}_{1}$ small pure white patches that extend via the centre of $\mathrm{M}_{2}$ to $\mathrm{CuA}_{1}$ in both sexes; near apex three larger buffy olive striae in both sexes; cilia long, $1.1 \mathrm{~mm}$ in male, $1.3 \mathrm{~mm}$ in female, cream-buff mixed with very long scales of pure white in both sexes. Underside of forewing rough-scaled, cream-buff mixed with olive, glossy, in both sexes. Hindwing upperside largely buffy olive, but olive ocher towards base of wing in both sexes, outer half with more striae in female, glossy; underside as in forewing. Wing venation see Figures 16a-17a. Abdomen: Mainly yellow ocher, mixed with cream-buff in female, glossy.

Male genitalia. Saccus broad and rounded caudally, finger-shaped, extending a little bit posteriorly towards sacculus; uncus large and broad, with a deep emargination, c. 55\% of the length of uncus; uncus densely setose on ventral surface with long setae, bilobed, lobes elongated (ventral view). Valva on ventral surface and on the upper half with two short thorn-like appendices, bent towards uncus, tips acuminate. In between of the two thorn-like appendices there is an elongated, narrow emargination that is as long as $60 \%$ of the width of valva. A weakly-sclerotized structure with long setae covers the ventral surface of the valva and two-thirds of the emargination. It extends from the costa towards the median sector of the valva. Costa, sacculus and median sector of valva covered with setae. Gnathos strongly bent towards uncus. A plate-like rectangular process, slightly larger than the saccus, extends into a large emargination that occurs at the outer base of the valva. Juxta oval-shaped without acuminate lobes. Phallus simple, tube-like, not bent; vesica without cornuti.

Female postabdominal structure. Papillae anales obliquely 8-shaped, beak-like and broad ventrally (lateral view); densely covered with short and long setae; segment 8 with few setae along its posterior margin. The base of the posterior apophysis is broad ( $5 \times$ broader than the tip of posterior apophysis) and long (slightly less than half of the posterior apophysis). The anterior apophyses are a little bit longer than the posterior apophyses and narrow. 
Diagnosis. The male of $M$. mineti sp. nov. has an uncus with two elongated, rather narrow lobes with a deep emargination in between (ventral view). The papillae anales of the female are beak-like but broad ventrally; the posterior apophysis of the female has a broad, elongated base that is almost as long as half of the posterior apophysis ( $c f$. Figures 24a-24b).

Distribution. M. mineti sp. mov. is known from Makoga. This locality is, according to the label of the type specimens, located in the canton de Gondey (southeastern Moyen-Chari, southern Chad). The new species most probably extends $16 \mathrm{~km}$ southwards into the Central African Republic.

Habitat of type locality. The Region du Moyen-Chari or Middle Chari (altitude 340-520m; average annual rainfall $900-1060 \mathrm{~mm}$ ) belongs to the "Sudanian regional centre of endemism" sensu White (1983). It is located in the humid tropical lowlands of the southern Lake Chad Basin and in southcentral Chad. The basin floor slopes upwards towards the south forming locally low sand and clay plateaus of Tertiary continental sediments. The soils comprise mainly lacustrine and alluvial sediment sequences. The plateau areas are geologically older and are locally called 'Koros'. They have altitudes of 40-50m and are naturally covered by legume-dominated dense woodlands (Bocquier \& Barbery 1968 ) and hence, appear to be typical habitats for Metarbelidae (Lehmann 2008a). 'Koros' occur as large patches $c .50 \mathrm{~km}$ north of the village Gondey, e.g. south and west of the town Singako, while the surrounding alluvial soils are much younger and are mainly covered by open woodlands that are not dominated by legumes. The landscape is dissected by numerous rivers and floodplains during the rainy season. Riparian forests occur along larger rivers. Endemism among plants, mammals, reptiles and birds is low (Magin 2004a). Some areas, e.g. the Manda National Park c. 90km northwest from the canton de Gondey, have a number of biome-restricted species (BirdLife International 2012). Its diverse flora comprises 368 species in the herbaceous and shrub layer alone, e.g. the solid-stemmed bamboo Oxytenanthera abyssinica (A. Rich.) Munro (Guisse et al. 2012).

The Moyen-Chari is characterized by large fertile croplands, e.g. sorghum, millet, peanuts, cassava, yam and garden vegetables. Cotton is an indigenous crop to southern Chad. Large-scale production of cotton was promoted (in particular in the southwestern Moyen-Chari) for export since 1920.

The canton de Gondey is located in the southeastern part of the Moyen-Chari, some kilometers east of the northern limit of cotton growing and $c$. 50km east of the Chari River. The Chari River is $c$. $1.200 \mathrm{~km}$ long and is the major river of Chad. The floodplains of the Chari and its tributaries, e.g. the rivers Mya, Bahr Aouk and Bahr Keita (mainly located in the canton de Gondey), are inundated during the rainy season (April-October). The landscape is largely an open and mixed wooded Sudanian savanna that is not dominated by woody legumes. The woodland grows mainly on alluvial soils; 'Koros' are absent. Gondey village is located in the southern part of the canton. Dominant tree species near Gondey (altitude 385m; average annual rainfall at Kyabé $c$. $50 \mathrm{~km}$ northwest of Gondey is 
1032mm) comprise: Anogeissus leiocarpus (DC.) Guill. \& Perr., Combretum glutinosum Perr., C. collinum Fresen. ssp. hypopilinum (Diels) Okafor, Terminalia macroptera Guill. \& Perr. (often near small rivers and sometimes on inundated land), Acacia sieberiana DC., Bauhinia reticulata DC. and, rather rare, Lannea humilis (Oliv.) Engl.. Along the main rivers of the canton de Gondey, the Mya and Bahr Aouk, tree species such as Bauhinia reticulata DC., Acacia seyal DC., Mitragyna inermis (Willd.) O.Ktze., Lannea humilis (Oliv.) Engl. and Diospyros mespiliformis Hochst. ex A.DC. are dominant and locally form a riparian forest. Trees such as Butyrospermum paradoxum (Gaertn. f.) Hepper, Parkia biglobosa (Jacq.), Guiera senegalensis J.F. Gmel., Annona senegalensis Pers. and Grewia mollis Juss. occur but are more common in the periphery of 'Koros', e.g. near Singako. In fallow woodland Pterocarpus lucens Guill. \& Perr., Grewia tenax (Forsk.) Fiori, G. mollis Juss., Parkia clappertoniana Keay and Bridelia scleroneura Müll. Arg. are characteristic secondary tree species (Bocquier \& Barbery 1968).

The type locality "Makoga" was not found by the author, neither on maps nor in old or modern textbooks. Hence, the habitat descriptions above refer to the whole canton de Gondey as well as to the surroundings of the village Gondey.

Ecology based on holotype. $M$. mineti sp. nov. occurs in a mosaic of riparian forest, open woodland and wooded floodplain grassland at low elevations (below $500 \mathrm{~m}$ ) comprising mainly tree species of genera that do not represent woody legumes, e.g. Anogeissus, Combretum, Terminalia and Mitragyna. The dominant tree species are mainly linked to the Sudanian Region.

Etymology. M. mineti sp. nov. is named for one of the leading scientists on the taxonomy of Lepidoptera, Professor Dr Joël Minet (Head of the Lepidoptera Section within the Département Systématique et Evolution, MNHN), for his kind provision of Metarbelidae as well as for our valuable discussions about various important characters of the family Metarbelidae during my visit in Paris.

Joël presented his Thesis about the tympanal organs of the Pyraloidea ("Eléments pour une étude phylogénétique des organes tympaniques des Pyrales, Lepidoptera Pyraloidea") in November 1980 at the "Université Paris XI (Orsay)" where he had followed courses in Entomology. His "Habilitation à diriger des recherches (HDR)" (PhD equivalent) was presented in March 1992 at "Université Paris VI" and dealt with ditrysian phylogeny ("Phylogénie des Lépidoptères ditrysiens"). Joël was promoted to MNHN Professor in December 1996. 


\section{Moyencharia joeli sp. mov.}

Figures 18A; 18a, b; 24c.

Material examined. Holotype male, Nigeria, Kaduna State, Kaduna, 13. April.1970, Dr Politzar leg., genitalia slide number 14/042012 I. Lehmann (ZSM).

Paratype one male, Nigeria, Gombe State, Bara, 15.June.1974, Dr Politzar leg., genitalia slide number 21/042012 I. Lehmann (ZSM).

Description. Forewing length in male holotype $10.0 \mathrm{~mm}$ (wingspan $22.0 \mathrm{~mm}$ ), in male paratype $9.0 \mathrm{~mm}$ (wingspan $21.5 \mathrm{~mm}$ ); antenna-wing ratio $0.60: 1$ in holotype, 0.56:1 in paratype. Head: Warm buff with sepia, in between eyes long hair-like scales, glossy; eyes black with wood brown patches; antennae bipectinate, same colour as head, branches of antennae $6 \times$ width of shaft, branches and shaft covered with warm buff scales dorsally, antennal tips with longer scales, bending towards apex; labial palpi warm buff. Thorax: Patagia and tegulae warm buff with glinty shine. Hindlegs of holotype broken; hindfemora, -tibiae and -tarsi of paratype warm buff with fine hair-like scales, glossy; tibial spurs $1.1 \mathrm{~mm}$ long (apical pair), medial pair with two spurs of different length, $1.1 \mathrm{~mm}$ and $0.6 \mathrm{~mm}$. Forewing warm buff and light orange-yellow mixed with sepia and clay colour, not glossy; a broad light orangeyellow subterminal band from $\mathrm{R}_{5}$ to $\mathrm{CuA}_{2}$; a band of the same colour along the costa and a patch of light orange-yellow at the base of forewing; at top of $\mathrm{CuA}_{2}$ a small pure white patch; in between base of $\mathrm{M}_{2}$ and $\mathrm{M}_{1}$ as well as below $\mathrm{CuA}_{2}$ sepia coloured patches; small spots of sepia along the termen, edged ivory yellow; in between $\mathrm{M}_{1}$ and $\mathrm{CuA}_{2}$ as well as below the outer half of $1 \mathrm{~A}+2 \mathrm{~A}$ a patch of clay colour; cilia long, $1.3 \mathrm{~mm}$, warm buff alternating with ivory yellow. Underside of forewing roughscaled, warm buff with scattered scales of sepia. Hindwing upperside warm buff and ivory yellow; underside as in forewing. Wing venation see Figure 18a. Abdomen: Mainly yellow ocher mixed with warm buff and a glinty shine; a small crest and a short abdominal tuft of sepia present.

Male genitalia. Saccus short anteriorly extending posteriorly to below sacculus of valva as narrow and long rod-like process, c. $35 \%$ of length of valva (lateral view), that is rounded caudally and fingershaped; uncus large and broad, bilobed, lobes not elongated with a flat emargination (ventral view); uncus densely setose with very long and rather broad setae that give the ventral surface an almost prickly appearance. Valva on ventral surface and on the upper half with two thorn-like appendices, bent towards uncus, tips acuminate. In between of the two thorn-like appendices there is an elongated, narrow emargination with a weakly-sclerotized structure. Along the costa, the sacculus and towards the median sector of the valva long setae occur. These setae have the same prickly appearance as those on the ventral surface of the uncus. Gnathos rather narrow in a lateral view and with short teeth-like structures at its distal end, bent towards uncus. A plate-like, rectangular process of the vinculum, not larger than the saccus, extends into an emargination that occurs at the outer base of the valva. Juxta 
oval-shaped and without acuminate lobes. Phallus simple, tube-like, strongly bent at one side; vesica without cornuti.

Variation. The male paratype does not differ to any major degree in regard to the holotype.

Female. Unknown.

Diagnosis. The male of $M$. joeli sp. nov. has got long setae on the ventral surface of the uncus, on the costa and sacculus extending to almost the median sector of the valva. These setae have a prickly appearance. The vinculum, and/or an appendice of the vinculum, extends below the valva (lateral view). It looks finger-like with a broad base in ventral view ( $c f$. Figures 18b, 24c).

Distribution. M. joeli sp. nov. is known from Kaduna (north-central Nigeria) and Bara (northeastcentral Nigeria). Bara $\left(10^{\circ} 22^{\prime} \mathrm{N}, 10^{\circ} 43^{\prime} \mathrm{E}\right.$; altitude $\left.330 \mathrm{~m}\right)$ is located c. $320 \mathrm{~km}$ east from Kaduna. The new species probably extends $290 \mathrm{~km}$ further east into northwestern Cameroon.

Habitat of type locality. Nigeria is the largest country in West Africa and is as densely populated as Western Europe. Hence, the increase in area of subsistence farming to feed a growing population and the spread of cash cropping by peasant farmers has destroyed all large areas of natural forest outside of protected areas. Natural forests were carefully managed until the early 1960s but forest exploitation had become virtually unregulated on a massive scale, both legally and illegally, by the 1980s. Forests are now largely restricted to protected areas (Sayer et al. 1992).

Kaduna ( $10^{\circ} 32^{\prime} \mathrm{N}, 7^{\circ} 26^{\prime} \mathrm{E}$; altitude $646 \mathrm{~m}$; average annual rainfall $\left.1285 \mathrm{~mm}\right)$ is located in the humid tropical lowlands of the Kaduna Plains and at the Kaduna River in north-central Nigeria. The climate of Kaduna is dominated by two strongly contrasting seasons, namely the dry-season with a cool dry north-easterly, dust-laden Harmattan wind that blows from the desert in October-April and obscures the sun as well as the rainy-season with a moist south-westerly wind that blows in MaySeptember. Kaduna belongs to the "Sudanian regional centre of endemism" sensu White (1983) and to the "Southern Guinea Savanna Zone" sensu Keay (1959a). The latter includes many forest fragments as well as many high-forest tree species in the savanna if not disturbed by cultivation or fire. Endemism among plants, mammals and birds is low and most endemic species have only survived in protected areas (Magin 2004b). Kaduna belongs to that part of the Kaduna Plains that has been occupied until recent times by a "Derived Savanna" sensu Keay (1959b) including forest remnants and open floodplain grasslands ('fadamas') with scattered low trees of Mitragyna inermis (Willd.) O. Ktze. and Terminalia glaucescens Benth.. Little of this savanna woodland was still present in 1976 (Blair Rains et al. 1977). Most of the woody vegetation of the "Derived Savanna" on the Kaduna Plains was not dominated by legumes (the association of Isoberlinia spp. - Monotes kerstingii Gilg Uapaca togoensis Pax was confined to shallow droughty soils further north of Kaduna) but comprised 
largely tree species such as Acacia gourmaensis A. Chev., Bombax costatum Pellegr. \& Vuillet, Bridelia ferruginea Benth., Combretum sericeum Don, Crossopteryx febrifuga (Afzel. ex G.Don) Benth., Cussonia barteri Seem., Daniellia oliveri (Rolfe) Hutch. \& Dalz., Lophira lanceolata Van Tiegh. ex Keay, Piliostigma thonningii (Schumach.), Terminalia avicennioides Guill. \& Perr. and T. laxiflora Engl.. The tree Terminalia glaucescens Benth. was often abundant on river terraces and alluvial soils, e.g. along the Kaduna River.

The true climax vegetation for Kaduna is wetter semi-deciduous forest with evergreen tree species of the "Drier peripheral semi-evergreen Guineo-Congolian rain forest and similar forest in the transition zones" sensu White (1983). Since extensive areas of the Kaduna Plains had been much modified by humans, e.g. forest clearing for cultivation, lopping for browse, burning and grazing by nomadic pastoralists, forest tree species occurred in few forest remnants in 1976 comprising, e.g. Albizia zygia (DC.) J.F. Macbr., Antiaris africana Engl., Aubrevillea kerstingii (Harms) Pelegr., Cola gigantea A. Chev., Khaya grandifoliola C. DC., Uvaria chamae P. Beauv. and Milicia excelsa (Welw.) C.C. Berg. Dense riparian forests once included Adina microcephala (Del.) Hiern, Syzygium guineense (Willd.) DC. and Ricinodendron heudelotii (Baill.) Pierre, but were already reduced to scattered trees, comprising often Khaya senegalensis (Desr.) A. Juss., in 1976 (Blair Rains et al. 1977).

Not only forest remnants but also most of the present woody savanna vegetation of the Kaduna Plains are a result of cultivation, recurrent dry-season fires and associated disturbance. Few large indigenous tree species are still common near Kaduna as those of Butyrospermum paradoxum (Gaertn. f.) Hepper. Only little patches of "Derived Savanna", moist and riparian forests still remain near Kaduna and hence, it is very likely that the habitat of the holotype does no longer exist.

Ecology based on holotype. M. joeli sp. nov. occurs in a mosaic of wooded farmland, 'fadamas', small patches of "Derived Savanna" as well as drier peripheral semi-evergreen Guineo-Congolian rain forest and riparian forest at low elevations (below $650 \mathrm{~m}$ ), comprising mainly tree species of genera that do not belong to woody legumes, e.g. Bridelia, Crossopteryx, Combretum, Terminalia, Mitragyna, Antiaris and Milicia. The dominant tree species are mainly linked to the wetter parts of the Sudanian Region and to the Guinea-Congolia/Sudania Transition Zone with its drier peripheral semievergreen lowland rain forest. It is important to note, that fierce dry-season fires occur in the "Derived Savanna" and hence, might reduce the habitats and populations of the new species. 
Etymology. M. joeli sp. nov. is named for Joel Mutisya Kioko (Nairobi) who received his MSc from the University of Oldenburg (Germany). He is the Director of Metrology and Testing at Kenya Bureau of Standards (KEBS) as well as the Vice Chairman of the Africa Metrology Organisation (AFRIMETS). Joel promotes the Mithanga School Development Team during his spare time for more than ten years. He organizes and oversights funds, the construction, renovation and repair of school buildings to support the rural community of Mumbuni Location.

I am very grateful for his honest friendship, his generous hospitality with his family in Nairobi since 1994 as well as for the unforgettable wonderful days we spent together in Mithanga with its nice people and pupils of Machakos District (south-central Kenya).

\section{Moyencharia winteri sp. nov.}

Figures 19A, 20A; 19a, b.

Material examined. Holotype female, South-Sudan, "Tembura" (today Republic of South Sudan, Western Equatoria State, Tambura County, Tambura) December.1922, Acq. Janson (London), on second label: "Ex Oberthür Coll., Brit. Mus. 1927-3", genitalia slide number 19/022012 I. Lehmann (BMNH).

Paratype one female, Haut-Uele, Moto town (today Democratic Republic of the Congo, Orientale Province, Moto) 11.March.1926, L. Burgeon leg., genitalia slide number 14/072012 I. Lehmann (RMCA).

Description. Forewing length in female holotype $15.5 \mathrm{~mm}$ (wingspan $32.0 \mathrm{~mm}$ ), in female paratype $13.0 \mathrm{~mm}$ (wingspan $29.0 \mathrm{~mm}$ ); antenna-wing ratio $0.45: 1$ in holotype, $0.46: 1$ in paratype. Head: Clay coloured scales with sepia towards tips and a glinty shine, in between eyes long hair-like scales; eyes wood brown with small black patches; antennae bipectinate, same colour as head, branches of antennae $1.5 \times$ width of shaft, branches and shaft covered with warm buff scales dorsally, antennal tips with longer scales, bending towards apex; labial palpi warm buff. Thorax: Patagia with a white collar ring; tegulae clay cloured, scales sepia towards tip, with a second pure white collar ring. Hindfemora, -tibiae and -tarsi warm buff with fine hair-like scales and a glinty shine; tibial spurs $1.3 \mathrm{~mm}$ long (apical pair) and $1.2 \mathrm{~mm}$ (medial pair). Forewing ecru-olive with striae and small patches of liver brown, glossy; a large ochraceous-tawny patch above $\mathrm{CuA}_{2}$, extending towards half of $\mathrm{M}_{2}$ as well as to the lower part of the discocellular cell; a small rounded patch of the same colour near the base of forewing; pure black from $\mathrm{CuA}_{2}$ towards dorsum with a patch of ochraceous-tawny below $1 \mathrm{~A}+2 \mathrm{~A}$; along termen alternating striae of pure white and liver brown; costa warm buff with striae of ecruolive; cilia long, $1.5 \mathrm{~mm}$, warm buff with sepia tips. Underside of forewing rough-scaled, ecru-olive, glossy. Hindwing upperside ecru-olive with a glinty shine; underside as in forewing. Wing venation 
see Figure 19a. Abdomen: Mainly ecru-olive mixed with warm buff, glossy; a short abdominal tuft present.

Variation. In the female paratype the areole is absent on the left forewing and present on the right forewing. Note that one forewing is broken in this specimen ( $c f$. Figure 20A). This forewing is fixed on a piece of paper that is attached below the paratype.

Male. Unknown.

Female postabdominal structure. Papillae anales obliquely 8 -shaped, beak-like and narrow ventrally (lateral view), densely covered with short setae; few setae along the posterior margin of segment 8 . The base of the posterior apophysis is broadened ( $3 \times$ broader than the tip of posterior apophysis) and long (as long as half of posterior apophysis). The anterior apophyses are slightly longer than the posterior apophyses and narrow.

Diagnosis. $M$. winteri sp. nov. differs from its congeners by distinctly darker forewing colours and in particular the pure black patches are outstanding. Hence, it cannot be considered as possibly conspecific to the males of joeli sp. nov., herhausi sp. nov. and sommerlattei sp. nov.. Moreover, these taxa do not occur sympatrically with $M$. winteri sp. nov.. The venation of the latter species represents the typical venation of Moyencharia g. nov. and the posterior apophysis of the female has the broad, elongated base that is almost as long as half of the posterior apophysis (Figure 19b). The papillae anales of the female of $M$. winteri sp. nov. is shaped beak-like and narrow ventrally (lateral view).

Distribution. M. winteri sp. nov. is known from Tambura (southwestern Sudan) and Moto (northeastern DRC). Moto is located c. $370 \mathrm{~km}$ southeast of Tambura. The new species extends most probably from Tambura $21 \mathrm{~km}$ east into the Central African Republic.

Habitat of type localities. The Republic of South Sudan is the youngest independent state of Africa, established on $09^{\text {th }}$ July 2011 after a six year lasting peace process. It was previously known as 'Southern Sudan'. The landscape is mainly a basin-like plain with elevations between $300-900 \mathrm{~m}$. There are few hills, e.g. the Didinga Hills and two mountain ranges, the Imatong Mountains with Mount Kinyeti $(3.181 \mathrm{~m}$, the highest peak in the country) and the Dongotona Mountains $(c .2 .600 \mathrm{~m})$. The Western Equatoria State (including Tambura County) and the mountain ranges have got the highest average annual rainfall of $1200-2200 \mathrm{~mm}$ in South Sudan. Two forest types occur only as relicts (often on fire protected sites) near the southwestern frontiers to the Central African Republic, DRC and Uganda. First, Afromontane Forest and secondly, drier types of Guineo-Congolian lowland tropical rain forest, e.g. large rain forests exist towards $\mathrm{Li}$ Yubu $(45 \mathrm{~km}$ southwest of Tambura) or as 
pockets in "Derived Savanna" sensu Keay (1959b). In contrast, riparian forests are present in the whole Western Equatoria.

Tambura (formerly Tembura; $5^{\circ} 36^{\prime} \mathrm{N}, 27^{\circ} 28^{\prime} \mathrm{E}$; altitude $645 \mathrm{~m}$ ) is a village according to one map of the Sudan Survey of 1932 (revised edition of 1976) and located 3km northeast of the ruins of Fort Hussinger in the south-central part of Tambura County (average annual rainfall 1335mm during 1974-2004 with two rainy seasons April-June and August-November). Tambura village is situated in a remoted area $21 \mathrm{~km}$ east of the frontier to the Central African Republic. It is on the borderline of the "Guinea-Congolia/Sudania Transition Zone" and the "Sudanian regional centre of endemism" sensu White (1983). The village is closely located to several swampy sites and rivers, e.g. $2 \mathrm{~km}$ south of the Yubo River and 5km north of the Moiko River. Hence, the Gambiense sleeping sickness, transmitted by Glossina fuscipes fuscipes Newstead, a riverine species of tsetse fly, is very common and regularly causes the death of many people around Tambura (records exist since 1918). Several rock formations as the Bukita and Wanga rocks occur $c .7 \mathrm{~km}$ southwest of Tambura (highest rock $812 \mathrm{~m}$ ).

The vegetation of Sudan was classified by Harrison \& Jackson (1958). According to this Tambura County is located in only one of six divisions, namely in the "High Woodland Savanna with high rainfall of $900-1300 \mathrm{~mm}$." The woodland is an open and broadleaved tree woodland, thorny trees are rare. The dominant genera include Anogeissus, Khaya and Isoberlinia. Dominant species around Tambura village include Anogeissus leiocarpus (DC.) Guill.\& Perr., Combretum binderianum Kotschy and Khaya senegalensis (Desr.) A. Juss.. Fires are fierce due to tall grasses, e.g. Hyparrhenia edulis C.E. Hubbard and Loudetia esculenta C.E. Hubbard. Towards the southwest woodlands occur with patches that are derived from lowland rain forest with Annona chrysophylla Bojer, Bridelia scleroneuroides Pax, Dombeya quinqueseta (Del.) Exell, Milicia excelsa (Welw.) C.C. Berg and Khaya grandifoliola C. DC. (FAO \& UNEP 1984). Towards Mupoi several younger Teak plantations exist, e.g. 16km southeast of Tambura. The village belongs to the "Greenbelt Zone" (Livelihood Profiles 2006) that is considered as a breadbasket of South Sudan. Households of Tambura village depend exclusively on agriculture to meet their food needs and woodlands were locally replaced by lime orchards (including old orchards), cotton fields, maize, groundnuts and finger millet. Wooded farm lands around Tambura comprise trees, e.g. Butyrospermum paradoxum ssp. niloticum (Kotschy) Hepper, Ficus religiosa L. (introduced) and Mangifera indica L..

Natural riparian forests occur around the village comprising trees, e.g. Khaya senegalensis (Desr.) A. Juss., Cola spp., Syzygium guineense (Willd.) DC., Mitragyna spp., Albizia zygia (DC.) J.F. Macbr., Acacia polyacantha Willd. ssp. campylacantha (Hochst. Ex A. Rich.) Brenan and Humularia sudanica P.A. Duvign in the undergrowth.

Since the paratype locality represents the most southern distribution record of the species of Moyencharia g. nov. and since it is situated in one of two major Pleistocene forest refuge areas of Central Africa, Moto is briefly described here. Moto ( $894 \mathrm{~m}$, average annual rainfall $1500-1800 \mathrm{~mm}$, one dry season January-March) is located $200 \mathrm{~km}$ east of Isiro and $60 \mathrm{~km}$ west of the Albertine Rift 
region (Orientale Province, northeastern DRC). The town is situated in the "Guineo-Congolian regional centre of endemism", but is in the transition to the "Guinea-Congolia/Sudania Transition Zone" sensu White (1983). The exposed geological landscape around Moto is one of the oldest in Africa and represents the Late Archean crust (3000-2500 million years old) of the African Platform. The exposed Late Archean Upper Zaire granitoid massif at Moto belongs to the oldest units of the Congo and Kibalian cratons, comprising c. 2600 million years old rocks of the Western Nile Formation with granite-gneiss domes as well as Late Archean greenstone belts (Goldfarb et al. 2001). The latter are exposed as rocks that are dark green in colour and consist mainly of mica and quartz. They occur as outcrops or open pits that are usually devoid of vegetation. The Moto Greenstone Belt includes important gold and other metallic deposits. Hence, the hilly terrain has been heavily converted and used for gold mining on a large scale since 1911. Degraded forest remnants, artisanal mines, cultivated lands and secondary moist grasslands dominate the landscape today and it is very likely that the habitat of the paratype does no longer exist.

The forest cover was continuous at Moto before 1911. The forests surrounding the outcrops belong to the "East Central Pleistocene forest refuge" that includes forest sites that are between 12000 and 3000 years old while the riverine forest sites are much older, probably at least 20000 years (Colyn et al. 1991). Dense moist forest remnants still occur near Moto today and belong according to Verhegghen et al. (2012) to the "Mixed moist semi-evergreen Guineo-Congolian rain forest" sensu White (1983). They have a very diverse flora and fauna with high endemism (Blom \& Schipper 2004). Tree species that occur near Moto comprise, e.g. Entandrophragma candollei Harms, E. cylindricum (Sprague) Sprague, Diospyros crassiflora Hiern and Dialium excelsum Louis ex Steyaert. South of Moto and towards Mongbwalu occur very rare tree species such as Brazzeia longipedicellata Verdc. (SRK Consulting 2011). Forest remnants, often degraded forest patches at Moto as well as forests towards the transition zone further north, include, e.g. Milicia excelsa (Welw.) C.C. Berg and Khaya anthotheca (Welw.) C. DC.. Riparian forests comprising, e.g. Turreanthus africanus (Welw. ex C.DC.) Pellegr., Berlinia grandiflora (Vahl) Hutch. \& Dalz., Cynometra vogelii Hook. f., Pterocarpus santalinoides L'Hérit ex DC., Parinari congensis F. Didr. and Hymenocardia ulmoides Oliv. (the latter two tree species extend further north into South Sudan).

Ecology based on holotype and paratype. M. winteri sp. nov. occurs in "Mixed moist semievergreen Guineo-Congolian rain forest" sensu White (1983) as well as in a mosaic of wooded farmland, swampy sites, "Derived Savanna" with drier peripheral semi-evergreen Guineo-Congolian rain forest and riparian forest at low elevations (below $1.300 \mathrm{~m}$ ). Various forest sites of the paratype locality are older than 12000 years. Dominant tree species belong to genera (in particular in drier areas) that are not woody legumes, e.g. Anogeissus, Bridelia, Khaya, Mitragyna, Antiaris, Diospyros, Hymenocardia and Milicia. Fierce dry-season fires occur in the habitat of the Sudanian Region and might reduce the populations of the new species. 
Etymology. M. winteri sp. nov. is named for Philip Enever Winter (Juba, South Sudan) who received his M.A. (Classics) from Cambridge University in 1971. Philip is Independent Diplomat's Representative working closely with the Government of the Republic of South Sudan in foreign relations and diplomacy. He has managed "Save the Children" Fund programmes for more than 25 years in the UK, Kenya, South Sudan, DRC, Burundi and Rwanda working with the UN, rebels and governments in three war zones. Several times Philip was Senior Advisor on diplomacy and conflict resolution, e.g. for the United Nations Organisation Mission in the DRC. He received The Most Excellent Order of the British Empire (O.B.E.) for "services to conflict resolution in Africa" in 2004.

Philip has done an outstanding favour for me during his work by the British Foreign Office as Chief of Staff to the former President of Botswana, Sir Quett Ketumile Joni Masire, who acted as Facilitator in the Inter-Congolese Dialogue. I am also very grateful for our various valuable conversations about Philip's life and work in very remote and dangerous areas of Africa.

\section{Moyencharia herhausi sp. nov.}

Figures 21A; 20a, b; 24d.

Material examined. Holotype male, Obervolta, Bobo Dioulasso (today Burkina Faso, Hauts- Bassins Region, Houet Province) 30. April.1975, Dr Politzar leg., genitalia slide number 09/042012

I. Lehmann (ZSM).

Description. Forewing length in male $12.5 \mathrm{~mm}$ (wingspan 26.0mm); antenna-wing ratio 0.56:1. Head: Warm buff mixed with ivory yellow, glossy, in between eyes long hair-like scales which are in length $c$. half of eye diameter; eyes wood brown with small black patches; antennae bipectinate, same colour as head, branches of antennae $5 \times$ width of shaft, branches and shaft covered with ivory yellow scales dorsally, antennal tips with longer scales, bending towards apex; labial palpi ivory yellow. Thorax: Patagia and tegulae ivory yellow with glinty shine. Hindfemora, -tibiae and -tarsi warm buff with fine hair-like scales, glossy; tibial spurs $1.2 \mathrm{~mm}$ long (apical pair), medial pair with two spurs of different length, $1.3 \mathrm{~mm}$ and $1.1 \mathrm{~mm}$. Forewing warm buff and light orange-yellow mixed with ivory yellow, not glossy; a broad light orange-yellow subterminal band from $\mathrm{R}_{5}$ towards near top of $\mathrm{CuA}_{2}$; a band of the same colour along the costa and a large patch of light orange-yellow at the base of forewing, the latter patch is edged with a smaller patch of sepia towards $\mathrm{CuA}_{2}$; at top of $\mathrm{CuA}_{2}$ a small pure white patch; small spots of sepia along costa and below $\mathrm{CuA}_{2}$; a reticulated pattern of sepia in between base of $\mathrm{R}_{5}$ and $\mathrm{R}_{3}$; lunules of ivory yellow along termen, edged sepia; in the outer half of the discocellular cell a patch of light orange-yellow edged sepia; cilia long, $1.5 \mathrm{~mm}$, alternating warm buff and light-orange yellow. Underside of forewing rough-scaled, warm buff with ivory yellow, some scales with sepia coloured tips. Hindwing upperside warm buff mixed with ivory yellow; underside as in forewing. 
Wing venation see Figure 20a. Abdomen: Mainly warm buff with ivory yellow, glossy; a small crest and a short abdominal tuft of sepia are present.

Male genitalia. Saccus very small anteriorly, but extending posteriorly to below sacculus of valva as narrow and long process (c. $40 \%$ width of valva; lateral view) that is rounded caudally and fingershaped (ventral view); uncus large and broad with a flat emargination, densely setose on ventral surface with short setae, bilobed, lobes not elongated. Valva on ventral surface and on the upper half with two thorn-like appendices, bent towards uncus, tips acuminate. In between of the two thorn-like appendices there is a broad emargination, c. $25 \%$ of the width of valva, with a weakly-sclerotized structure that covers two-thirds of this emargination. Along the costa, the sacculus and towards the median sector of the valva long setae occur. These setae do not have a prickly appearance. Gnathos rather broad in lateral view and bent towards uncus. A large plate-like rectangular process, broader than the emargination in between the thorn-like appendices, extends into an emargination that occurs at the outer base of the valva. Juxta oval-shaped and without acuminate lobes. Phallus simple, tubelike, strongly bent at one side, at its bended end with two tiny processes; vesica without cornuti.

Femalle. Unknown.

Diagnosis. Saccus very small anteriorly, but extending posteriorly to below sacculus of valva as narrow and long process (lateral view). The uncus has got a flat emargination and is densely setose with short setae ventrally. The phallus is strongly bent at one side. At its upper end two tiny processes occur (cf. Figures 20b, 24d).

Distribution. M. herhausi sp. nov. represents, together with Kroonia carteri Lehmann 2010a from Sénégal, one of the most northern records of the Metarbelidae on the African mainland. The new species is the first published record of the family Metarbelidae for the country Burkina Faso. It is known from Bobo Dioulasso (southwestern Burkina Faso). M. herhausi sp. nov. most probably extends from Bobo Dioulasso $110 \mathrm{~km}$ westwards into southeastern Mali.

Habitat of type locality. The majority of Burkina Faso is situated on a savanna plateau (altitude $200-$ $300 \mathrm{~m}$ ) and has got a long dry season (October-April) and a short rainy season (May-September). In general, the diversity of the flora and fauna in Burkina Faso is not well known. Trees, woody shrubs and creepers comprise 376 species including 95 exotic species. Among the 30000 estimated insect species only 1515 species have been recorded (Ministry of Environment and Water 1999). Endemism is low among plants, mammals and birds (Magin 2004b).

Bobo Dioulasso $\left(11^{\circ} 10^{\prime} \mathrm{N}, 04^{\circ} 16^{\prime} \mathrm{W}\right.$; altitude $462 \mathrm{~m}$; average annual rainfall $1000 \mathrm{~mm}$ based on records of 1971-2000) is located in the Sudanese domain that is less arid and covers the southern part 
of the country. The town and its environment belong to the "Sudanian regional centre of endemism" sensu White (1983). Historically, areas close to Bobo Dioulasso were an important producer of natural rubber from natural plantings of Landolphia heudelotii A. DC., a shrub or climber that usually grows near rivers, at the beginning of the last century. During World War II, different states of French West Africa provided 3446 tons of rubber as their contribution to the war effort against Hitlerian fascism (Aubréville 1950). Bobo-Dioulasso is largely surrounded by tall-grass savanna that can be classified as "Sudanian woodland" sensu White (1983). It is not dominated by Acacia spp. but comprising broad-leaved tree species, e.g. Lannea microcarpa Engl. \& K. Krause, Ximenia americana L., Ficus ingens Miq., Combretum micranthum G. Don, Erythrophleum africanum (Welw. ex Benth.) Harms, Bombax costatum Pellegr. \& Vuillet, Swartzia madagascariensis Desv., Acacia hockii De Wild., A. macrostachya Reichenb. ex Benth. and Tricalysia okelensis Hiern. Trees of rather secondary savanna vegetation include, e.g. Burkea africana Hook., Daniellia oliveri (Rolfe) Hutch. \& Dalz. and Parkia biglobosa (Jacq.) Benth.. Relicts of dry forest occur, often constituting 'sacred woods' and hence have survived until present, e.g. northwest and west of Bobo Dioulasso. Two examples are the Forét la Guinguette (surrounding the spring of the river Kou) and the Forét Classée du Kou (116ha). The latter is located c. $14 \mathrm{~km}$ west of Bobo Dioulasso and has survived because it is legally protected since 1935 . Half of the forest is a "Sudanian swamp forest and riparian forest" sensu White (1983) that borders the Kou River. It comprises, e.g. Detarium microcarpum Guill. \& Perr., Berlinia grandiflora (Vahl) Hutch. \& Dalz., Ficus congoensis Engl., Kigelia africana (Lam.) Benth., Vitex doniana Sw., Cola laurifolia Mast., Elaeis guineensis Jacq., Carapa procera DC., Dialium guineense Willd., Macrosphyra longistyla (DC.) Hiern, Adenia cissampeloides (Planch. ex Benth.) Harms, Euphorbia macrophylla Pax, Mimusops kummel A. DC., Bauhinia rufescens Lam. and Adina microcephala (Del.) Hiern. The other $50 \%$ can be classified as "Sudanian transition woodland" sensu White (1983) that still includes forest trees, e.g. Antiaris africana Engl. and large trees of Ceiba pentandra (Linn.) Gaertn., a secondary forest species that often occurs close to savannas. The woodland associates comprise species such as Anogeissus leiocarpus (DC.) Guill. \& Perr., Diospyros mespiliformis Hochst. ex A. DC., Linociera nilotica Oliv., Pterocarpus erinaceus Poir., Celtis integrifolia Lam., Acacia pennata (Linn.) Willd. and Garcinia ovalifolia Oliv..

Ecology based on holotype. $M$. herhausi sp. nov. occurs in a mosaic of wooded farmland, Sudanian woodland with pockets of dry and riparian forest at low elevations (below $500 \mathrm{~m}$ ).

Etymology. M. herhausi sp. nov. is named for Frank Herhaus (Wiehl, Germany) who studied landscape ecology at the University of Duisburg-Essen. He is an executive secretary of the regional nature conservation stations Oberberg/ Rhein-Berg (state of North Rhine-Westphalia) which are involved in various activities and projects on nature and environment protection, landscape management, inventories of protected areas, landscape ecology and environment education based on a 
collaboration with several larger nature conservation associations at the state level. Frank is a member of the advisory board of the German Association for Landcare, an umbrella organization of $c .140$ local or regional German landcare organizations. He has published several papers on the diversity and protection of stone quarries, valley bogs and bats in Germany.

I first met Frank in Arnsberg in 1984 when I was 19 years old and just six months after two years of political imprisonment by the Government of the GDR. I am very grateful for his honest friendship since that time and for his valuable help in various ways in particular during 1984-1989.

\section{Moyencharia sommerlattei sp. nov.}

Figures 22A; $21 \mathrm{a}, \mathrm{b} ; 24 \mathrm{e}$.

Material examined. Holotype male, Guinée Française (today Republic of Guinea), no locality, no date, no collector; on second label "1920-1932, Ex coll. L. \& J. de Joannis, muséum Paris", genitalia slide number 22/022012 I. Lehmann (MNHN).

Description. Forewing length in male $10.5 \mathrm{~mm}$ (wingspan $24.0 \mathrm{~mm}$ ); antenna-wing ratio $0.57: 1$. Head: Warm buff mixed with ivory yellow, in between eyes long hair-like scales which are in length $c$. half of eye diameter; eyes wood brown with small black patches; antennae bipectinate, same colour as head, branches of antennae $7 \times$ width of shaft, branches and shaft covered with ivory yellow scales dorsally, antennal tips with longer scales, bending towards apex; labial palpi narrow and warm buff. Thorax: Patagia and tegulae warm buff with glinty shine, patagia with an ivory yellow collar ring. Hindfemora, -tibiae and -tarsi ivory yellow with fine hair-like scales, glossy; tibial spurs long, $1.1 \mathrm{~mm}$ (apical pair), medial pair with two spurs of different length, $1.0 \mathrm{~mm}$ and $0.9 \mathrm{~mm}$. Forewing with a broad band of warm buff along the costa including a few sepia coloured striae, ivory yellow patches below this band, patches edged sepia with smoke grey in between; one ivory yellow patch at top of $\mathrm{CuA}_{2}$; a broad patch of olive-ocher extending from $\mathrm{CuA}_{2}$ via the outer half of the discocellular cell towards apex; below $\mathrm{CuA}_{2}$ small patches of smoke grey edged sepia, glossy; a large patch of warm buff at the base of forewing; lunules of ivory yellow along termen, edged sepia; one narrow patch of smoke grey from $\mathrm{CuA}_{1}$ to apex, glossy; cilia long, $1.2 \mathrm{~mm}$, alternating warm buff and ivory yellow. Underside of forewing rough-scaled, warm buff, some scattered scales with sepia coloured tips. Hindwing upperside warm buff with ivory yellow, glossy; underside as in forewing. Wing venation see Figure 21 . Abdomen: Mainly warm buff with ivory yellow and a glinty shine; one small crest and one short abdominal tuft of sepia are present. 
Male genitalia. Saccus small anteriorly and not extending posteriorly to below sacculus of valva, rounded caudally; uncus large and broad with a flat emargination, densely setose on ventral surface with short setae, bilobed, lobes not elongated (ventral view). Valva on ventral surface and on the upper half with two thorn-like appendices, bent towards uncus, tips acuminate; the base of the upper appendice with a small oval-shaped weakly-sclerotized hole (visible only before mounting in Euparal, cf. Figure $21 \mathrm{~b}$ ). In between of the two thorn-like appendices there is a broad emargination, c. $25 \%$ of the width of valva, with a weakly-sclerotized structure that has long scattered setae and covers twothirds of this emargination. Along the costa, the sacculus and towards the median sector of the valva long setae occur. Gnathos rather broad in lateral view and bent towards uncus. A large plate-like rectangular process, broader than the emargination in between the thorn-like appendices, extends into an emargination that occurs at the outer base of the valva. Juxta oval-shaped and without acuminate lobes. Phallus simple, tube-like, broad, not bent, with two tiny acuminate processes at one end; vesica without cornuti.

Female. Unknown.

Diagnosis. Saccus small anteriorly, not extending posteriorly to below sacculus of valva, not fingershaped. The phallus is broad, not bent and has got two tiny acuminate processes at one end. The valva is $\mathrm{C}$-shaped (best visible in ventral view) between the lower thorn-like appendice and the sacculus. Hence, the valva extends slightly posteriorly at its ventral side ( $c f$. Figures $21 \mathrm{~b}, 24 \mathrm{e}$ ).

Distribution. M. sommerlattei $\mathbf{s p . ~ n o v . ~ i s ~ k n o w n ~ f r o m ~ t h e ~ R e p u b l i c ~ o f ~ G u i n e a ~ ( W e s t ~ A f r i c a ) . ~}$

Habitat of type locality. Unknown. The majority of Guinea comprises lowlands. There are only few highland areas, namely the Fouta Djallon with Mount Loura $(1.538 \mathrm{~m})$ and the 'Dorsale Guinéene' which includes Pic de Fon $(1.656 \mathrm{~m})$, Mount Nimba $(1.752 \mathrm{~m})$ and the Ziama massif $(1.387 \mathrm{~m})$. The latter two mountain ranges have got high rare and endemic species richness among plants, mammals, reptiles, birds and insects (Wieringa \& Poorter 2004). Montane forests are rare in West Africa. Guinea has only $210 \mathrm{~km}^{2}$ of montane forest dominated by, e.g. Parinari excelsa Sabine (Sayer et al. 1992) and Uapaca chevalieri Beille along streams (Poorter et al. 2004).

The lowland areas of Guinea become increasingly dry towards the north and east. Guinea straddles the Upper Guinea tropical lowland rain forest, the moist transitional savanna/forest mosaic and the drier Sudanian Region towards the north. The majority of the northern half of Guinea was originally covered with lowland dry forests (except of the Fouta Djallon) and receiving an average annual rainfall of $1250-1600 \mathrm{~mm}$ and a dry season of 3-7 months. These lowland dry forests were largely destroyed by humans in the last century. Dominant tree species comprised, e.g. in the west Parkia biglobosa (Jacq.) Benth., Pterocarpus erinaceus Poir. and solid-stemmed bamboo 
Oxytenanthera abyssinica (A. Rich.) Munro in the undergrowth; in the north Afzelia africana Pers., Khaya grandifoliola C. DC., Tabernaemontana africana Hook.; in the east Erythrophleum guineense G. Don and in the south Uapaca togoensis Pax, Isoberlinia doka Craib \& Stapf and I. dalzielii Crain \& Stapf. A number of riparian forests still occur in these drier areas including trees, e.g. Anisotes guineensis Lindau, Cathormion rhombifolium (Benth.) Keay with Ixora hiernii Scott-Elliot in the understory. The southwestern part of Guinea is still covered with "Mixed moist semi-evergreen Guineo-Congolian rain forest" sensu White (1983) comprising $4482 \mathrm{~km}^{2}$ (Sayer et al. 1992) including Upper Guinea endemic tree species such as Anthocleista nobilis G. Don as well as trees with a wider distribution, e.g. Anthonotha fragrans (Baker f.) Exell \& Hillcoat, Chrysophyllum giganteum A. Chev., Erythrophleum ivorense A. Chev., Funtumia africana (Benth.) Stapf, Parinari excelsa Sabine and Piptadeniastrum africanum (Hook. F.) Brenan. The average annual rainfall in this area is 1700 $2700 \mathrm{~mm}$.

The coastal areas receive very high average annual rainfall $(>3000 \mathrm{~mm})$. Almost the entire coast of Guinea is covered by mangrove forests, often dominated by Rhizophora harrisonii Leechman. Swamp and riparian forests occur including, e.g. Ficus ottoniifolia (Miq.) Miq. ssp. multinervia C.C. Berg and Raphia palma-pinus (Gaertn.) Hutch.. Other coastal forest types were once widespread and rich in Terminalia ivorensis A. Chev., Milicia excelsa (Welw.) C.C. Berg, Aningeria and Carapa spp. (Sayer et al. 1992; Poorter et al. 2004).

Ecology based on holotype. $M$. sommerlattei sp. nov. most probably occurs in various (mainly riparian?) forest types at low elevations (below $1.300 \mathrm{~m}$ ) with an average annual rainfall of at least $1250 \mathrm{~mm}$.

Etymology. M. sommerlattei sp. nov. is named for Dr Herbert Sommerlatte (born on the $01^{\text {st }}$ November 1905 in Berlin, died on the $20^{\text {th }}$ January 1995 in Zug/Switzerland) in remembrance of our interesting time spent together discussing his various geological explorations in Africa.

Herbert Sommerlatte was one of the first German mining engineers to receive a DAAD Exchange Research Fellowship for a post-graduate study in the United States of America in 1932 1934. During his long professional career he worked on various mining projects in such countries as Burma, India, South Africa, Rhodesia, Congo, Mozambique and Ethiopia and on a variety of mineral deposits which included, e.g. gold, Witwatersrand ores, chrome ores and zinc. His personal interests included researching the history of geology whereby he was one of the first ten persons to research one of the most important and earliest geological and mineral distribution maps, the "Turin papyrus", of the area of Wadi Hammamat (Eastern Desert, Egypt) that dates from the reign of RAMSES (Ra-messes) IV (c. 1156-1150 or 1153-1147 B.C.). Herbert Sommerlatte was probably the first who 
interpreted the striae in the spotted pattern on the papyrus as systematic drawings of near-surface gold deposits. His result was confirmed by the two scientists J.A. Harrel \& V.M. Brown only three years before he died. In 1987, Herbert Sommerlatte published his book "Gold and Ruins of Zimbabwe" (translated from German) about the self-taught geographer and geologist Karl Mauch (1837-1875) who produced one of the earliest geological maps of the area between the Vaal River and the Zambezi River (southeastern Africa) and as the first German, additional information of the Great Zimbabwe ruins which he visited in 1871 .

6. Moyencharia ochreicosta (Gaede, 1929), comb. nov.

Original combination: Teragra ochreicosta Gaede, 1929

Synonyms: Teragra basiplaga Gaede, 1929

Teragra basiplaga f. fuscoradiata Gaede, 1929.

Figures 23A-27A; 22a, b; 23a, b; 24f.

Material examined. Holotype male, West Africa, "Kete-Kratje" (today Kete-Krachi, Krachi West District, Volta Region, Ghana), no date, Graf Zech S. G. leg., genitalia slide number 13/122009 I. Lehmann (ZMHB).

Note: The collector of the holotype was Julius Graf von Zech auf Neuhofen who was the Gouvenor of the German Colony Togoland in 1905-1910. Togoland included eastern Ghana. Graf von Zech arrived in Kete-Krachi (southeast-central Ghana) in 1895 where he was appointed Executive Officer at the German Administration Station Kete-Krachi in the same year. He left Kete-Krachi and moved to Anecho in 1900. Hence, the author assumes that the holotype was collected in Kete-Krachi between 1895-1900.

Additional specimens: one male (probably from the type series of Teragra basiplaga, $c f$. note below) labelled "Gold Coast, Gambaga, 05.May.1902, Dr Bury" and on second label "f. fuscoradiata det. M. Gaede", genitalia slide number 17/082007 I. Lehmann (BMNH).

Note: Gaede (1929, p. 511) mentioned two "types" from the "Gold Coast" (today Ghana) for Teragra basiplaga, namely one for T. basiplaga and one for Teragra basiplaga f. fuscoradiata. The author found nine specimens in the BMNH that were collected in Gambaga by Dr Bury. According to the authors' opinion all nine specimens belong to one species since all have the same wing pattern. Two specimens, among the nine mentioned above, are determined as Teragra ochreicosta. The remaining seven specimens include one "type" determined as T. basiplaga and labelled "Gold Coast, Gambaga, Dr Bury" and on second label "f. fuscoradiata det. M. Gaede." The second "type" was not found by the author. It seems that Gaede included the seven specimens from Gambaga directly into one type series comprising T. basiplaga as well as f. fuscoradiata (cf. Article 72.4.1 ICZN 1999). 
One specimen of this type series (?) from Gambaga was dissected and studied by the author and is mentioned above (Figure 27A).

Two other specimens in the BMNH bear the label "Gold Coast, N. Territories, Kete-Krachi, A.W. Cardinall, B.M. 1925-146" and "Gold Coast, N. Territories, Kete-Krachi, A.W. Cardinall, B.M. 1925-241." Both are incorrectly determined as Metarbela micra Karsch. A genitalia dissection of the latter specimen was done by the author (genitalia slide number 18/082007 I. Lehmann) and indicates that it is the male of Moyencharia ochreicosta (Gaede, 1929). The second specimen also belongs to the latter species.

One male, North Nigeria, Zungeru, 17.April.1911, Scott Macfie leg., B.M. 1911-269, genitalia slide number 07/112006 I. Lehmann (BMNH); one male, South Nigeria, Lagos, no date, no collector and on second label "Teragra ochreicosta det. M. Gaede", genitalia slide number 30/072012 I.Lehmann (BMNH); one male, Obervolta (today Burkina Faso), Kourinyon (= misspelling of Kourignon near Nbié, Hauts-Bassins Region),“Voltaquellen”, 16.April.1975, Dr Politzar leg., genitalia slide number 23/012012 I. Lehmann (ZSM); one female, same locality, same date and collector, genitalia slide number 07/042012 I. Lehmann (ZSM).

Additional re-description. Forewing length in male holotype $11.0 \mathrm{~mm}$ (wingspan $23.5 \mathrm{~mm}$ ), in female $10.0 \mathrm{~mm}$ (wingspan 21.0mm); antenna-wing ratio 0.55:1 in male holotype, 0.45:1 in female. Head: Deep colonial buff, scales around eyes with tips of amber brown, in between eyes long hair-like scales; eyes ecru-olive with light brownish olive patches; antennae bipectinate, same colour as head, branches of antennae $8 \times$ width of shaft, branches and shaft covered with pale olive-buff scales dorsally, antennal tips with longer scales, bending towards apex; labial palpi narrow, slightly longer than diameter of eye and deep colonial buff. Thorax: Patagia and tegulae deep colonial buff, tips of scales amber brown, without collar ring. Hindfemora, -tibiae and -tarsi warm buff with fine hair-like scales, glossy; tibial spurs long, $1.1 \mathrm{~mm}$ (apical pair), medial pair with two spurs of different length, $1.0 \mathrm{~mm}$ and $0.9 \mathrm{~mm}$. Forewing warm buff and ivory yellow or light orange-yellow and ivory yellow, not glossy; a broad band of light orange-yellow, e.g. in specimens from Burkina Faso, or ivory yellow, e.g. in specimens from Nigeria, along the costa including sepia coloured striae from near apex to near base of forewing in both sexes; one small and elongated white or light orange-yellow patch at top of $\mathrm{CuA}_{2}$ in both sexes; a broad patch of sepia from below $\mathrm{CuA}_{2}$ and below of the discocellular cell towards the base of forewing in both sexes; base of forewing from costa to dorsum light orange-yellow or ivory yellow in both sexes; lunules ivory yellow or light orange-yellow along termen, edged sepia; a broad patch of deep olive-buff from $\mathrm{CuA}_{1}$ to the centre of $\mathrm{R}_{5}$; cilia long, $1.5 \mathrm{~mm}$, warm buff or light orange-yellow. Underside of forewing rough-scaled, deep colonial-buff. Hindwing upperside warm buff with ivory yellow towards the base of hindwing, glossy; underside as in forewing. Wing venation see Figures 22a, 23a. Abdomen: Mainly warm buff with ivory yellow; one small crest and one short abdominal tuft of sepia are present. 
Variation. The forewing upperside is mainly warm buff and ivory yellow in specimens from southeast-central Ghana (Kete-Krachi) as well as northern and southern Nigeria (Zungeru, Lagos) or mainly light orange-yellow and ivory yellow in specimens from northeastern Ghana (Gambaga) as well as western Burkina Faso (Kourignon). The latter specimens are largely light orange-yellow with little ivory yellow. However, the venation and genitalia of the latter specimens do not differ to any major degree to the holotype from Kete-Krachi (cf. Figures 23A-27A).

Male genitalia. Saccus absent or extremely short anteriorly but extending posteriorly just to below base of sacculus (c. $10 \%$ of width of valva), finger-like, rounded caudally (ventral view); uncus large and broad with a flat emargination, densely setose with short setae on ventral surface, bilobed, lobes not elongated. Valva on the ventral surface and on the upper half with two thorn-like appendices, bent towards uncus, tips acuminate. In between of the two thorn-like appendices there is a broad emargination, c. $25 \%$ of the width of valva, weakly-sclerotized with long scattered setae. Along the costa, the sacculus and towards the median sector of the valva long setae occur. Gnathos rather broad in lateral view, bent towards uncus. A large plate-like rectangular process, broader than the emargination in between the thorn-like appendices, extends into an emargination that occurs at the outer base of the valva. Juxta large, oval-shaped and without acuminate lobes. Phallus simple, tubelike, broad, strongly bent; vesica without cornuti.

Female postabdominal structure. Papillae anales obliquely 8-shaped and rather elliptic, less beaklike, broad dorsally (lateral view); densely covered with short and long setae; segment 8 with few scattered long setae on its lateral surface; long setae along posterior margin occur. The base of the posterior apophysis is very broad ( $7 \times$ broader than the tip of posterior apophysis) and long ( $c$. half of the posterior apophysis). The anterior apophyses are as long as the posterior apophyses, narrow and with a wave-like shape in the middle.

Diagnosis. Saccus absent or extremely short anteriorly, but extending posteriorly just to below base of sacculus (c. $10 \%$ of width of valva), finger-shaped. The phallus is broad and strongly bent. The valva is not C-shaped between the lower thorn-like appendice and the sacculus (cf. M. sommerlattei sp. nov.).

In the female, segment 8 has few scattered long setae on its surface and few long setae along its posterior margin. The base of the posterior apophysis is very broad $(7 \times$ broader than the tip of posterior apophysis) and long (c. half of the posterior apophysis). 
Distribution. M. ochreicosta is known from West Africa. It occurs in western Burkina Faso (Kourignon) extending its range southwards via northeast and southeast Ghana to southeast and eastcentral Nigeria. M. ochreicosta most probably occurs in the countries Togo and Benin that are located in between Ghana and Nigeria.

Habitat of type localities. The most spectacular topographical feature of Ghana is the Voltaian Escarpment (762m) that extends over much of eastern Ghana and is associated to the Gambaga Scarp $(518 \mathrm{~m})$ in the northeast. Montane zones, as defined by Keay (1959a) for tropical Africa, do not exist in Ghana. The highest hill of the country being Mount Afadjato or Afadjoto (885m), adjoining the Agumatsa Range c. $90 \mathrm{~km}$ southeast of Kete-Krachi.

Kete-Krachi (altitude $110 \mathrm{~m}$; average annual rainfall $1422 \mathrm{~mm}$ ) is located in southeast-central Ghana and in the south-central part of the Voltaian Basin. The town belongs to the "GuineaCongolia/Sudania regional transition zone" sensu White (1983). The Voltaian Basin has undergone tremendous environmental changes since the formation of Lake Volta, one of the largest man-made lakes. The Akosombo Dam, that flooded the basin, was officially opened on $22^{\text {nd }}$ January 1966.

The following description of Kete-Krachi refers to the old Kete-Krachi that is, except of a handful of old German buildings, under water since 1966. Hence, the holotype locality does no longer exist.

Many Middle Stone Age sites have been recorded around Kete-Krachi and available evidence indicates that by at least 4000 years ago various ethnic groups inhabitat that place (Agorsah 1988). Additionally, Kete-Krachi used to be an important port at the Volta River where slaves from the north where shipped in boats to river ports further south. It was also a nodal point on a main north-south caravan route. Hence, the vegetation around Kete-Krachi was modified by people for some millennia. Kete-Krachi was surrounded by three main vegetation types: First, a riparian forest of the "GuineaCongolia/Sudania regional transition zone" sensu White (1983). This was a large forest that extended along the Volta River, e.g. to the village Dadiase $2 \mathrm{~km}$ south of Kete-Krachi. Many people, e.g. the Krachi, used to live in this riparian forest. Tree species at Kete-Krachi comprised Hymenocardia heudelotii Müll. Arg., Afzelia africana Pers., Erythrophleum guineense G. Don, Berlinia grandiflora (Vahl) Hutch. \& Dalz. and the shrub Rotula aquatica Lour.. Secondly, the "Derived Savanna" sensu Keay (1959b) with tree species, e.g. Lophira lanceolata Van Tiegh. ex Keay, Hannoa undulata (Guill. \& Perr.) Planch., Lannea acida A.Rich., Parinari curatellifolia Planch. ex Benth., Parkia clappertoniana Keay, Albizia lebbeck (Linn.) Benth., Ficus polita Vah1, F. ovata Vahl, F. platyphylla Del. with shrubs such as Tricalysia chevalieri K. Krause, Teramnus buettneri (Harms) Bak.f. and Erythrococca anomala (Juss. ex Poir.) Prain. Thirdly, pockets of "Drier peripheral semi-evergreen Guineo-Congolian rain forest and similar forest in the transition zone" sensu White (1983). This type of forest occurred as far as $100 \mathrm{~km}$ northeast of Kete-Krachi where dense, large forests were described by Jeník \& Hall (1966). The small moist forest tree Vernonia colorata (Willd.) Drake that grows in 
forest pockets around the modern Kete-Krachi is probably a good indicator for a larger moist forest that occurred there before 1966. Common trees of this once larger forest type included Antiaris africana Engl., Ricinodendron heudelotii (Baill.) Pierre, Milicia excelsa (Welw.) C.C. Berg and Anogeissus leiocarpus (DC.) Guill. \& Perr.. Jeník \& Hall (1966) observed northeast of the old KeteKrachi, that except of the riparian forests, almost all the area was burnt annually.

Gambaga (altitude 385m; average annual rainfall 1143mm) belongs to the "Sudanian regional centre of endemism" sensu White (1983) and lies c. 300km north of Kete-Krachi and c. 50km west of the frontier to Togo. It is located close to the northern end of the Voltaian Basin and just south of the Gambaga Scarp. Gambaga was largely surrounded by (dry?) forests towards the north and northeast according to the vegetation map of the Survey of Ghana printed in 1969. East as well as west of Gambaga once large riparian forests occurred, termed "Sudanian swamp forest and riparian forest" sensu White (1983), along the tributaries of the White Volta River comprising, e.g. Berlinia grandiflora (Vahl) Hutch. \& Dalz., Zanha golungensis Hiern, Adina microcephala (Del.) Hiern, Psychotria psychotrioides (DC.) Roberty with shrubs such as Crotalaria spp., Culcasia saxatilis A.Chev. and Tephrosia mossiensis A.Chev.. All forests are smaller in size today. Based on the survey of 1969 occurred (and still occur) south and southeast of Gambaga "Guinea savanna woodland" with low inselbergs and outcrops as well as with a stony savanna surface on the remaining area. This surface was briefly described by Brash (1962). According to this, e.g. bauxitized laterite occurs as ironpan outcrops. The latter belong to the old Gondwana surface or to the early Tertiary surface. However, small trees on such outcrops include, e.g. Gardenia sokotensis Hutch., Plectranthus hallii J.K. Morton, Entada spp., orchids such as Eulophia quartiniana A.Rich and tall grasses, e.g. Andropogon pteropholis W.D. Clayton. A very common savanna tree around Gambaga is Prosopis africana Taub.. Other legume tree species include, e.g. Swartzia madagascariensis Desv., Piliostigma reticulatum (DC.) Hochst., Isoberlinia dalzielii Craib \& Stapf and Acacia dudgeoni Craib ex Holl.. Additionally, Combretum micranthum G. Don, C. collinum Fresen. ssp. hypopilinum (Diels) Okafar , C. nigricans var. elliotii (Engl. \& Diels), Ficus abutilifolia (Miq.) Miq., with local stands of the solidstemmed bamboo Oxytenanthera abyssinica (A.Rich.) Munso, occur. These tree species form woodlands towards the escarpment of the Gambaga Scarp.

Ecology. M. ochreicosta occurs at low elevations (below 500m) with an average annual rainfall of at least $1150 \mathrm{~mm}$. It is noteworthy that all localities that are mentioned above for Burkina Faso, Ghana and Nigeria occur close to rivers with riparian forests. Hence, it is likely that $M$. ochreicosta is a rain forest and/or riparian forest species that prefers various forest types, e.g. "Drier peripheral semievergreen Guineo-Congolian rain forest and similar forest in the transition zone"sensu White (1983). M. ochreicosta probably extends from forests into the wooded savanna and/or "Derived Savanna" sensu Keay (1959b). 


\section{Acknowledgements}

I am very grateful to Professor Dr Johann-Wolfgang Wägele, Dr Dieter Stüning and Karin Ulmen (ZFMK, Bonn) for their kind advice and technical assistance. Dr Hossein Rajaei (Bonn) kindly photographed the genitalia in the ventral view at ZFMK. I thank Dr Tim Davenport (Wildlife Conservation Society, Tanzania Program Director) who contributed important and unpublished information about the locality of Naitolia (Tanzania) and Heike Langenheim (Apelern, Germany) for correcting my language. Sebastian Fechner and Stefan Kornath (Hamburg) kindly produced the plates.

I would like to thank Martin Honey (BMNH, London), Dr Wolfgang Speidel and Thomas Josef Witt (MWM, Munich), Dr Esther Kioko (NMK, Nairobi), Dr Johannes Bergsten (NRM, Stockholm), Dr Jurate de Prins and Dr Ugo Dall'Asta (RMCA, Tervuren), Ole Karsholt (ZMUC, Copenhagen), Dr Wolfram Mey (ZMHB, Berlin) and Dr Axel Hausmann (ZSM, Munich) for allowing me to study their museums' collections of the Metarbelidae species (Mountelgonia g. nov. and Moyencharia g. nov.) in the frame of my $\mathrm{PhD}$ project at the University of Bonn.

\section{References}

Agorsah, E.K. (1988). The settlement history of the Northern Volta Basin in Ghana. National Geographic Research, 4(3), 371-385.

Aubréville, A. (1950). Flore forestière Soudano-Guinéenne: Afrique Occidentale Française, Cameroun, Afrique Équatoriale Française. Société d'Éditions Géographiques Maritimes Coloniales. Paris, 523 pp.

Beentje, H.J. (1990). The forests of Kenya. Mitteilungen des Instituts fiur Allgemeine Botanik Hamburg. Band 23a, pp. 265-286.

BirdLife International (2012). Important Bird Areas. Factsheet Chad. Available from http://www.birdlife.org

Blair Rains, A., Lawton, R.M., Mansfield, J.E. \& Rose Innes, R. (1977). Land resources of central Nigeria. Environmental aspects of the Kaduna Plains. Volume 2: Climate and vegetation. Ministry of Overseas Development, Land Resources Devision, Surbiton, Surrey, England. Land Resource Report, 19, pp. i-ix $+1-77$.

Blom, A. \& Schipper, J. (2004). Northeastern Congolian Lowland Forests. In: Burgess, N., D'Amico Hales, J., Underwood, E., Dinerstein, E., Olson, D., Itoua, I., Schipper, J., Rickketts, T., and Newman, K. (Eds.), Terrestrial ecoregions of Africa and Madagascar : a conservation assessment. World Wildlife Fund (United States), Island Press, Washington, pp. 244-246. 
Bocquier, G. \& Barbery, J. (1968). Notice Explicative - Carte Pédologique de Reconnaissance AU 1/200.000, Feuille Singako. ORSTOM, Centre de Fort-Lamy. Paris, 113 pp.

Brash, H.T. (1962). Geomorphology. In: Wills, B.J. (Ed.), Agriculture and Land Use in Ghana. Published for the Ghana Ministry of Food and Agriculture by the Oxford University Press, London, pp. 77-87.

Burgess, N., D’Amico Hales, J., Underwood, E., Dinerstein, E., Olson, D., Itoua, I., Schipper, J., Rickketts, T. and Newman, K. (Eds.) (2004). Terrestrial ecoregions of Africa and Madagascar : a conservation assessment. World Wildlife Fund (United States), Island Press, Washington, xxiii + $499 \mathrm{pp}$.

Chidumayo, E.N. (1997). Miombo ecology and management: an introduction. IT Publications \& Stockholm Environment Institute. Hants, U.K., 166 pp.

Colyn, M., Gautier-Hion, A. \& Verheyen, W. (1991). A re-appraisal of palaeoenvironmental history in Central Africa: evidence for a major fluvial refuge in the Zaire Basin. Journal of Biogeography, $18,403-407$.

Dalla Torre, K.W. von \& Strand, E. (1923). Lepidarbelidae. In: Strand, E. (Ed.), Lepidopterorum Catalogus, Volume 4: Pars 28, pp. 3-10. W. Junk, Berlin.

De Prins, J. \& De Prins, W. (2012). Afromoths, online database of Afrotropical moth species (Lepidoptera). Belgian Biodiversity Platform. Available from http://www.afromoths.net

Edwards, D.C. \& Bogdan, A.V. (1951). Important grassland plants of Kenya. Sir Isaac Pitman \& Sons Limited, Nairobi, $124 \mathrm{pp}$.

Edwards, E.D., Gentili, P., Horak, M., Kristensen, N.P. \& Nielsen, E.S. (1998). The Cossoid/Sesioid Assemblage. In: Kristensen, N.P. (Ed.), Lepidoptera, Moths and Butterflies. Volume 1: Evolution, Systematics and Biogeography. Handbook of Zoology, volume IV, part 35. Walter de Gruyter, Berlin, New York, pp. 181-197.

FAO \& UNEP (1984). Forest resources of tropical Africa. Part II: Country briefs. Sudan-Technical report, No. 2, 1-29. Report prepared by FAO and UNEP in 1981, Rome, Italy. Reprinted 1984.

Fischer, E., Killmann, D., Delepierre, G. \& Lebel, J.P. (2010). The orchids of Rwanda. Koblenz Geographical Colloquia, Series Biogeographical Monographs, 2, 438 pp.

Fletcher, D.S. \& Nye, I.W.B. (1995). Volume 4: Bombycoidea, Castnioidea, Cossoidea, Mimallonoidea, Sesioidea, Sphingoidea. In: Nye, I.W.B. (Ed.), The generic names of moths of the world. The Natural History Museum, London, $192 \mathrm{pp}$.

Fletcher, T.B. (1922). Notes and Oberservations. The Entomologist, LV (713), p. 231.

Gaede, M. (1929). 21. Family: Metarbelidae. In: Seitz, A. (Ed.), The Macrolepidoptera of the World. Volume 14: The African Bombyces and Sphinges. Alfred Kernen, Stuttgart, pp. 501-513 + pl. 78. Goldfarb, R.J., Groves, D.I. \& Gardoll, S. (2001). Orogenic gold and geologic time: a global synthesis. Ore Geology Reviews, 18, 1-75. 
Guisse, A., Saradoum, G., Diallo, A. and Ngom Faye, M. (2012). Characterization of the Herbaceous Vegetation of the National Park of Manda in Chad. International Journal of Science and Advanced Technology, 2(6), 1-10.

Hamilton, A.C. (1984). Deforestation in Uganda. Oxford University Press with The East African Wildlife Society, Nairobi, pp. 1-95.

Hamilton, A., Taylor, D. \& Howard, P. (2001). Hotspots in African forests as Quaternary Refugia. In: Weber, W., White, L.J.T., Vedder, A. \& Naughton-Treves, L. (Eds.), African rain forest ecology and conservation : an interdisciplinary perspective. Yale University Press, New Haven and London, pp. 57-67.

Hampson, G.F. (1909). Ruwenzori expedition reports. 11. Lepidoptera Heterocera. Arbelidae. Transactions of the Zoological Society of London. Volume xix, p. 133.

Hampson, G.F. (1910). Descriptions of new African moths. Arbelidae. Annals and Magazine of Natural History, 8(6), 117-128.

Hampson, G.F. (1914). Two new species of wood-boring moths from West Africa. Bulletin of Entomological Research, 5, $245+$ pl. 17.

Harrison, M.N. \& Jackson, J.K. (1958). Ecological classification of the Vegetation of the Sudan. Forests Bulletin, No. 2, 1-45. Agricultural Publications Committee, Khartoum, Sudan.

Hitimana, J., Kiyiapi, J.L. \& Njunge, J.T. (2004). Forest structure characteristics in disturbed and undisturbed sites of Mt. Elgon Moist Lower Montane Forest, western Kenya. Forest Ecology and Management, 194(1-3), 269-291.

Holland, W.J. (1893). Descriptions of new species and genera of West African Lepidoptera. Psyche, Cambridge, 6, 393-400.

Holloway, J.D. (1986). The moths of Borneo. Part 1: Key to families: Cossidae, Metarbelidae, Ratardidae, Dudgeoneidae, Epipyropidae and Limacodidae. Malayan Nature Journal, 40, 1-165, +9 pls.

International Commission on Zoological Nomenclature (ICZN) (1999). International Code of Zoological Nomenclature. Fourth Edition. The International Trust for Zoological Nomenclature. The Natural History Museum, London, 306 pp.

Janse, A.J.T. (1925). A revision of the South A frican Metarbelinae. South African Journal of Natural History, 5, 61-100+5 pls.

Jeník, J. \& Hall, J.B. (1966). The ecological effects of the Harmattan wind in the Djebobo Massif (Togo Mountains, Ghana). Journal of Ecology, 54, 767-779.

Jordan, K. (1907). New African Zygaenidae. The Entomologist, 40(529), 121-127.

Keay, R.W.J. (1959a). An outline of Nigerian Vegetation. Third edition, Government Printer, Lagos, pp. $1-46$.

Keay, R.W.J. (1959b). Derived savanna - derived from what? Bulletin de l'Institut Fondamental d' Afrique Noire Serie A, 21(2), 427-438. 
Kelman, I. (2004). Victoria Basin Forest-Savanna Mosaic. In: Burgess, N., D’Amico Hales, J., Underwood, E., Dinerstein, E., Olson, D., Itoua, I., Schipper, J., Rickketts, T. and Newman, K. (Eds.), Terrestrial ecoregions of Africa and Madagascar : a conservation assessment. World Wildlife Fund (United States), Island Press, Washington, pp. 291-293.

Kerfoot, O. (1964). The vegetation of the South-West Mau Forest. East African Agricultural and Forestry Journal, April 1964, 295-318.

Kinyanjui, M.J. (2011). NDVI-based vegetation monitoring in Mau forest complex, Kenya. African Journal of Ecology, 49(2), 165-174.

Klots, A.B. (1970). Lepidoptera. In: Tuxen, S.L. (Ed.), Taxonomist's Glossary of Genitalia in Insects. Munksgaard, Copenhagen, pp. 115-130.

Lawton, R.M. (1963). Palaeoecological and ecological studies in the Northern Province of Northern Rhodesia. Kirkia, 3, 46-77.

Lawton, R.M. (1978). A study of the dynamic ecology of Zambian vegetation. Journal of Ecology, 66, 175-198.

Le Cerf, F. (1914). Diagnoses sommaires de Lépidoptères nouveaux de l'Afrique orientale anglaise. Bulletin de la Société entomologique de France, 8, 399-401.

Lehmann, I. (1997). Metarbela haberlandorum spec. nov., a new moth from Kenya (Lepidoptera: Metarbelidae). Nachrichten Entomologischer Verein Apollo, 18(1), 45-53.

Lehmann, I. (2007). Metarbelidae. In: Mey, W. (Ed.), The Lepidoptera of the Brandberg Massif in Namibia. Part 2. Esperiana Memoir, 4, 169-185+ pl.17.

Lehmann, I. (2008a). Ten new species of Metarbelidae (Lepidoptera: Cossoidea) from the coastal forests and the Eastern Arc Mountains of Kenya and Tanzania, including one species from two upland forests. Journal of East African Natural History, 97(1), 43-82.

Lehmann, I. (2008b). Six new species of Metarbelidae (Lepidoptera: Cossoidea) from the Eastern Arc Mountains of Tanzania, including one new species from Marenji Forest in southeast coastal Kenya. Journal of East African Natural History, 97(2), 187-206.

Lehmann, I. (2010a). A new genus of Metarbelidae (Lepidoptera: Cossoidea) from the Afrotropical Region with the description of seven new species. Esperiana Memoir, 5, 294-321 + pl. 21.

Lehmann, I. (2010b). A revision of the genus Arbelodes Karsch (Lepidoptera: Cossoidea: Metarbelidae) from southeast-central and southern Africa with the description of thirteen new species. Published by the author, Hamburg \& Wismar, 82 pp., 8 b/w pls., 5 colour pls.

Lehmann, I. (2011). The description of a new genus and twenty-three new species of Metarbelidae (Lepidoptera: Cossoidea) from the lowland tropical rain forests of the Guineo-Congolian Region with notes on habitats and biogeography. Published by the author, Hamburg, 67 pp., $10 \mathrm{~b} / \mathrm{w}$ pls., 6 colour pls., 1 coloured map. 
Lehmann, I. (2012). Description of a new genus and species of Metarbelidae (Lepidoptera, Cossoidea) from the Albertine Rift region of Tanzania, East Africa. Norwegian Journal of Entomology, 59, 234-240.

Lehmann, I. \& Kioko, E. (2000). Preliminary survey on butterflies and moths and their habitats in two Kaya forests of the Kenya coast. Metamorphosis - Journal of the Lepidopterists' Society of Africa. Occasional supplement 4, 1-52.

Lehmann, I. \& Kioko, E. (2005). Lepidoptera diversity, floristic composition and structure of three Kaya forests on the south coast of Kenya. Journal of East African Natural History, 94, 121-163.

Livelihood Profiles (2006) (in draft). Southern Sudan Livelihood Profiles. Written in collaboration with Save the Children UK and USAID Famine Early Warning Systems Network. Southern Sudan Centre for Census, Statistics and Evaluation (SSCCSE). Juba, South Sudan.

Lundberg, J. \& McFarlane, D.A. (2006). Speleogenesis of the Mount Elgon elephant caves, Kenya. Geological Society of America. Special Paper 404, 51-63.

Magin, C. (2004a). East Sudanian Savanna. In: Burgess, N., D’Amico Hales, J., Underwood, E., Dinerstein, E., Olson, D., Itoua, I., Schipper, J., Rickketts, T. and Newman, K. (Eds.), Terrestrial ecoregions of Africa and Madagascar : a conservation assessment. World Wildlife Fund (United States), Island Press, Washington, pp. 285-286.

Magin, C. (2004b). West Sudanian Savanna. In: Burgess, N., D’Amico Hales, J., Underwood, E., Dinerstein, E., Olson, D., Itoua, I., Schipper, J., Rickketts, T. and Newman, K. (Eds.), Terrestrial ecoregions of Africa and Madagascar : a conservation assessment. World Wildlife Fund (United States), Island Press, Washington, pp. 282-284.

Masharabu, T. (2011). Climate change risks to ecosystems and biodiversity in Ruvubu National Park, Burundi. UDSM/ IRA, Dar es Salaam, 10 pp. Unpublished presentation.

Michuki, J., Kiyiapi, J., Nkako, F., Noor, H., Mwinzi, M., Kipngetich, J., Kiroken, A. \& Lambrechts, C. (2008). Mau Complex and Marmanet forests. Environmental and economic contributions. Current state and trends. Naishi, Lake Nakuru, pp. 1-33. Unpublished briefing notes.

Ministry of Environment and Water (1999). Country study on Burkina Faso biodiversity.

Conducted by the National Technical Committee of the Convention on the Biological Diversity under the aegis of the Ministry in charge of Environment and Water. Published by the Permanent Secretariat of the National Council for the Management of the Environment. Ouagadougou, Burkina Faso, 156 pp.

Mutanen, M., Wahlberg, N. \& Kaila, L. (2010). Comprehensive gene and taxon coverage elucidates radiation patterns in moths and butterflies. Proceedings of the Royal Society B, 277, 2839-2848.

New, C. (1873). Life, Wanderings, and Labours in Eastern Africa. With an account of the first successful ascent of the equatorial snow mountain, Kilima Njaro and remarks upon East African Slavery. Frank Cass and Company Limited, London, 528 pp. + 1 map. 
Nkako, F.M., Lambrechts, C., Gachanja, M. \& Woodley, B. (2005). Maasai Mau Forest Status Report 2005. Ewaso Ngiro South Development Authority, Narok, Kenya, pp. 1-32.

Poorter, L., Bongers, F., Kouamé, F.N'. \& Hawthorne, W.D. (2004) (Eds.), Biodiversity of West African forests : an ecological atlas of woody plant species. CABI Publishing, Cambridge, MA, $521 \mathrm{pp}$.

Regier, J.C., Zwick, A., Cummings, M.P., Kawahara, A.Y., Cho, S., Weller, S., Roe, A., Baixeras, J., Brown, J.W., Parr, C., Davis, D.R., Epstein, M., Hallwachs, W., Hausmann, A., Janzen, D.H., Kitching, I.J., Solis, M.A., Yen, S.-H., Bazinet, A.L. \& Mitter, C. (2009). Toward reconstructing the evolution of advanced moths and butterflies (Lepidoptera: Ditrysia) : an initial molecular study. BMC Evolutionary Biology, 9 (1), 280.

Richards, P.W. (1959). The types of vegetation of the Humid Tropics in relation to the soil. Joint Unesco/CCTA Symposium on Vegetation in relation to the soil in the plains and lower mountain regions of the equatorial and sub-equatorial zones and in the adjoining tropical areas. Adiopodoumé-Abidjan, Ivory Coast, 20-24 October 1959, pp.1-11. Unpublished presentation.

Richards, P.W. (1998). The tropical rain forest : an ecological study. Cambridge University Press, Cambridge, reprint, pp. ix-xxiii + 1-575.

Ridgway, R. (1912). Color Standards and Color Nomenclature. Published by the author, Washington, 43 pp. +53 pls.

Sayer, A.J., Harcourt, C.S. \& Collins, N.M. (1992). The Conservation atlas of tropical forests. Africa. IUCN. Macmillan Publishers, 288 pp.

Scoble, M.J. (1995). The Lepidoptera: form, function and diversity. The Natural History Museum in association with Oxford University Press, London, 404 pp.

Sibatani, A., Ogata, M., Okada, Y. \& Okagaki, H. (1954). Male genitalia of Lepidoptera: Morphology and Nomenclature. I. Divisions of the valvae in Rhopalocera, Phalaenidae (= Noctuidae) and Geometridae. Annals Entomological Society of America, 47, 93-106.

Smith, P.P. \& Trapnell, C.G. (2002). Chipya in Zambia : a review. Kirkia, 18(1), 16-34.

SRK Consulting (2011). Mongbwalu Project. Final draft environmental impact study and management plan of the project for public disclosure. Volume 1: EIS and EMPP report. Report No. 438643. Johannesburg (SRK Consulting South Africa) and Lubumbashi (SRK Consulting CONGO), i-xxxv + 1-439 pp.

Strand, E. (1909). Lepidoptera aus Deutsch-Ostafrika gesammelt von Herrn Oberleutnant Wintgens. Familie Metarbelidae (Hollandiidae). Deutsche Entomologische Zeitschrift „Iris “, 22, 118-121.

Van Dyck, H. (2011). Habitat-use in butterflies: how to move from structural to functional ecology. Abstracts of the XVIIth European Congress of Lepidopterology, Luxembourg 9-13 May, 2011, 9. 
van Nieukerken, E.J., Kaila, L., Kitching, I.J., Kristensen, N.P., Lees, D.C., Minet, J., Mitter, C., Mutanen, M., Regier, J.C., Simonsen, T.J., Wahlberg, N., Yen, S.-H., Zahiri, R., Adamski, D., Baixeras, J., Bartsch, D., Bengtsson, B.Å., Brown, J.W., Bucheli, S.R., Davis, D.R., De Prins, J., De Prins, W., Epstein, M.E., Gentili-Poole, P., Gielis, C., Hättenschwiler, P., Hausmann, A., Holloway, J.D., Kallies, A., Karsholt, O., Kawahara, A.Y., Koster, S., Kozlov, M.V., Lafontaine, J.D., Lamas, G., Landry, J.-F., Lee, S., Nuss, M., Park, K.-T., Penz, C., Rota, J., Schmidt, B.C., Schintlmeister, A., Sohn, J.-C., Solis, M.A., Tarmann, G.M., Warren, A.D., Weller, S., Yakovlev, R.V., Zolotuhin, V.V. \& Zwick, A. (2011). Order Lepidoptera Linnaeus, 1758. In: Zhang, Z.Q. (Ed.), Animal biodiversity : An outline of higher-level classification and survey of taxonomic richness. Zootaxa, 3148, 212-221.

Verhegghen, A., Mayaux, P., de Wasseige, C. \& Defourny, P. (2012). Mapping Congo Basin vegetation types from $300 \mathrm{~m}$ and $1 \mathrm{~km}$ multi-sensor time series for carbon stocks and forest areas estimation. Biogeosciences, 9, 5061-5079.

Walker, F. (1854). Euchromia diptera. In: List of the specimens of Lepidopterous insects in the collection of the British Museum. Part I. - Lepidoptera Heterocera. Printed by Order of the Trustees of the British Museum (Natural History), London, p. 264.

Walker, F. (1855). Genus 45. Teragra. In: List of the specimens of Lepidopterous insects in the collection of the British Museum. Part V. - Lepidoptera Heterocera. Printed by Order of the Trustees of the British Museum (Natural History), London, pp. 1064-1065.

White, F. (1979). The Guineo-Congolian Region and its relationships to other phytochoria. Bulletin du Jardin Botanique National de Belgique, 49, 11-45.

White, F. (1983). The Vegetation of Africa : a Descriptive Memoir to Accompany the Unesco/AETFAT/UNSO Vegetation Map of Africa. Natural Resources Research XX. Unesco, Paris, $356 \mathrm{pp}$.

White, L.J.T. (2001). The African rain forest. Climate and vegetation. In: Weber, W., White, L.J.T., Vedder, A. \& Naughton-Treves, L. (Eds.), African rain forest ecology and conservation : an interdisciplinary perspective. Yale University Press, New Haven and London, pp. 3-29.

Wieringa, J.J. \& Poorter, L. (2004). Biodiversity hotspots in West Africa; patterns and causes. In: Poorter, L., Bongers, F., Kouamé, F.N'. \& Hawthorne, W.D. (Eds.), Biodiversity of West African forests : an ecological atlas of woody plant species. CABI Publishing, Cambridge, MA, United States of America, pp. 61-72. 
$16 \mathrm{~A}$

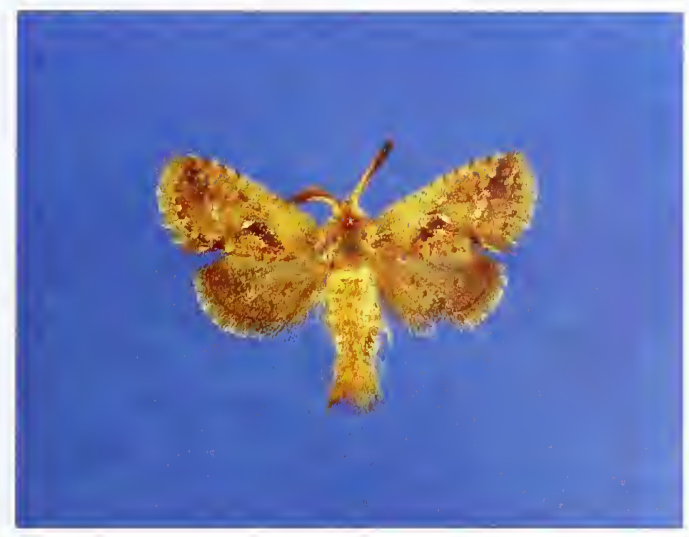

$20 \mathrm{~mm}$
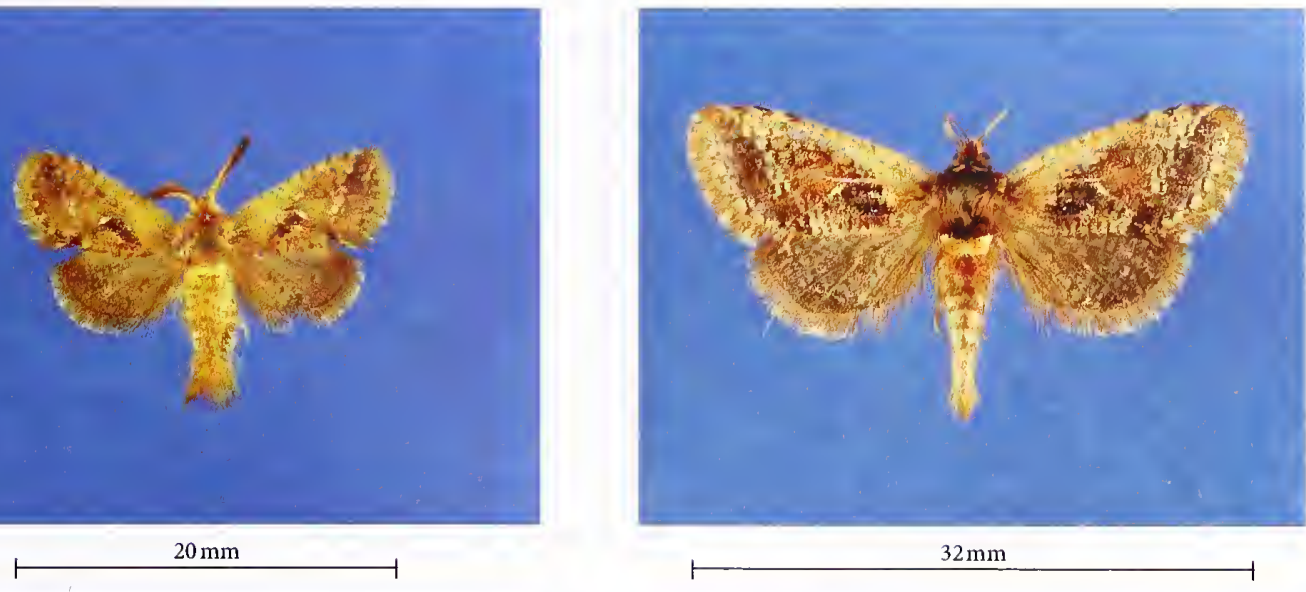

$18 \mathrm{~A}$

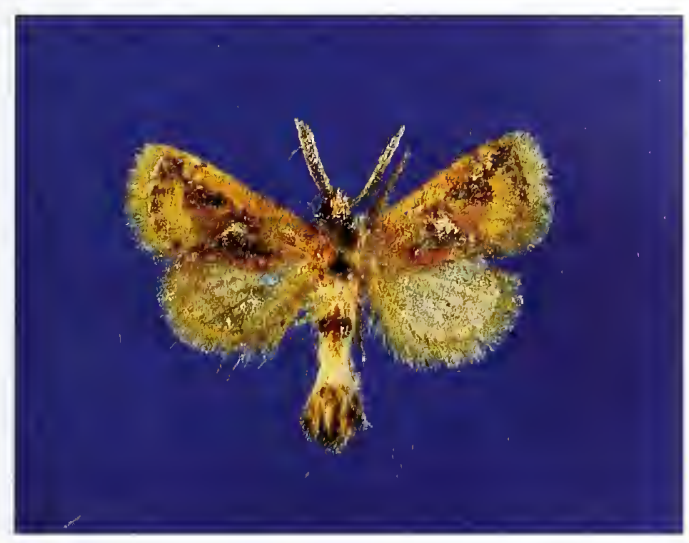

$22 \mathrm{~mm}$
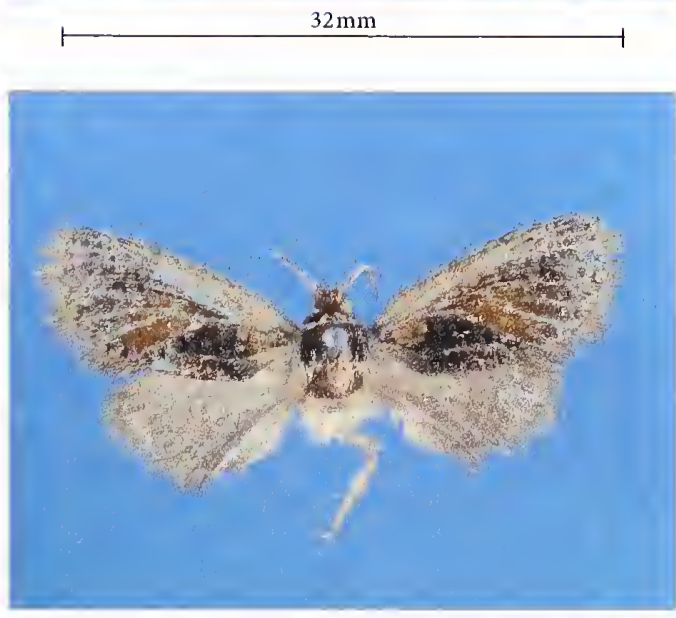

$19 \mathrm{~A}$

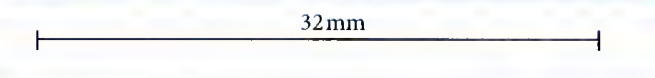

$20 \mathrm{~A}$

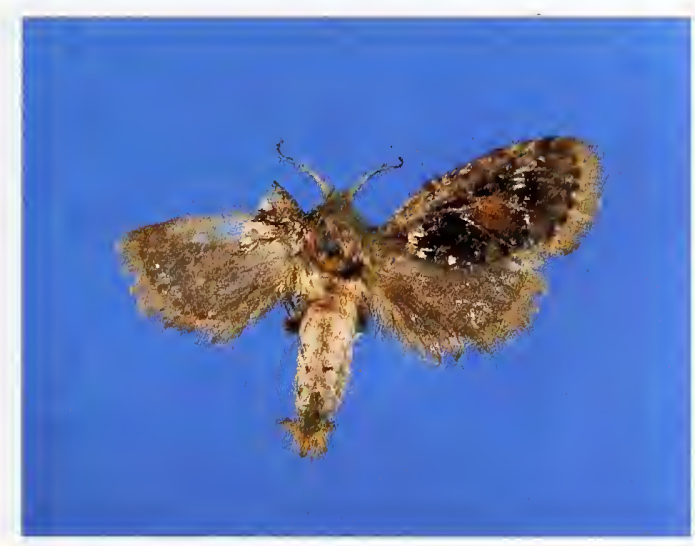

$29 \mathrm{~mm}$

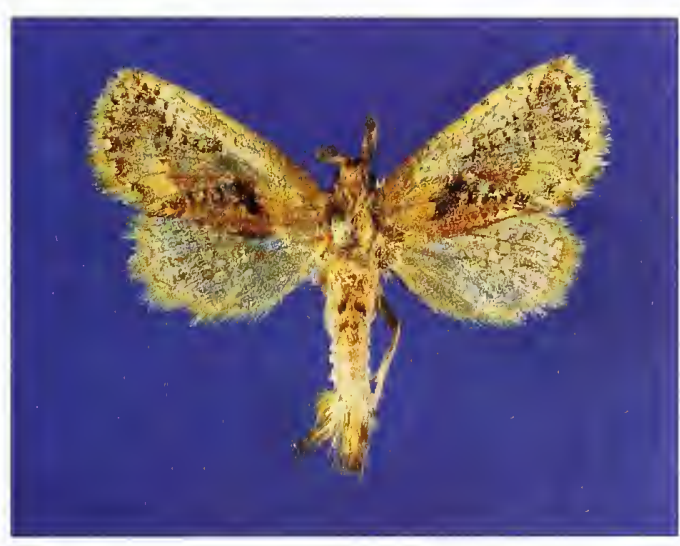

Figure 16A. Moyencharia mineti sp. nov., male, holotype, Chad, Moyen-Chari Region, Canton de Gondey.

Figure 17A. Moyencharia mineti sp. nov., female, paratype, Chad, Moyen-Chari Region, Canton de Gondey.

Figure 18A. Moyencharia joeli sp. nov., male, holotype, Nigeria, Kaduna State, Kaduna town.

Figure 19A. Moyencharia winteri sp. nov., female, holotype, Republic of South Sudan, Western Equatoria State, Tambura.

Figure 20A. Moyencharia winteri sp. nov., female, paratype, Democratic Republic of the Congo, Orientale Province, Moto.

Figure 21A . Moyencharia herhausi sp. nov., male, holotype, Burkina Faso, Hauts-Bassins Region, Bobo Dioulasso. 


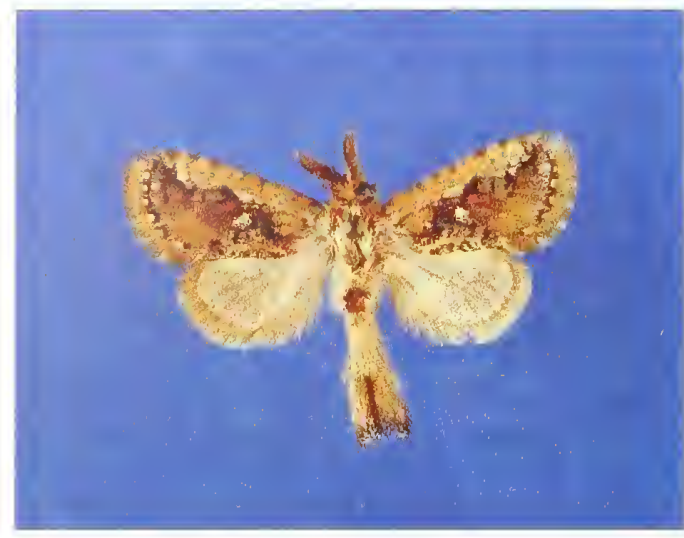

$23 \mathrm{~mm}$

$24 \mathrm{~A}$

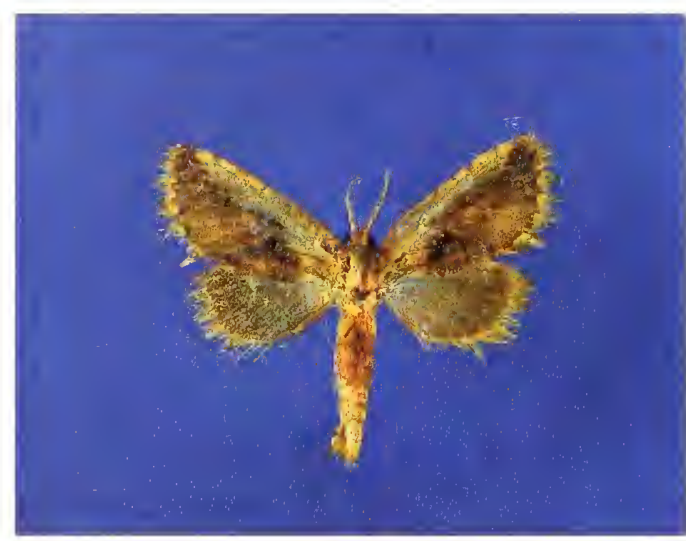

$21 \mathrm{~mm}$

26A

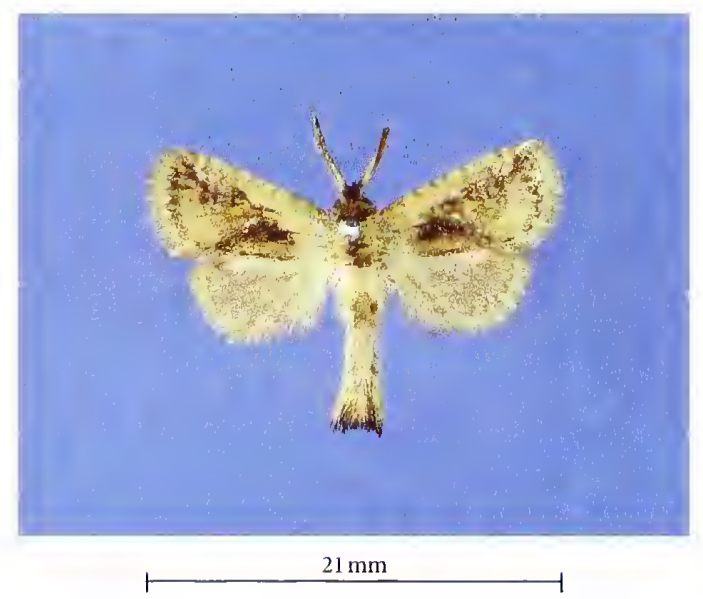

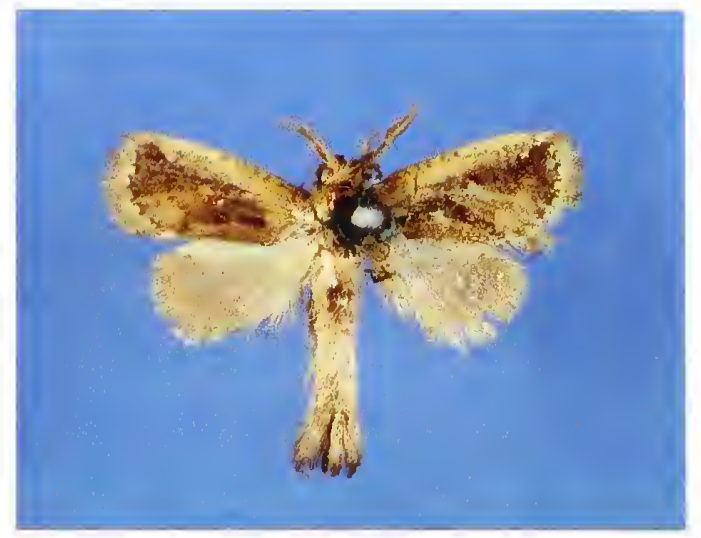

$23,5 \mathrm{~mm}$

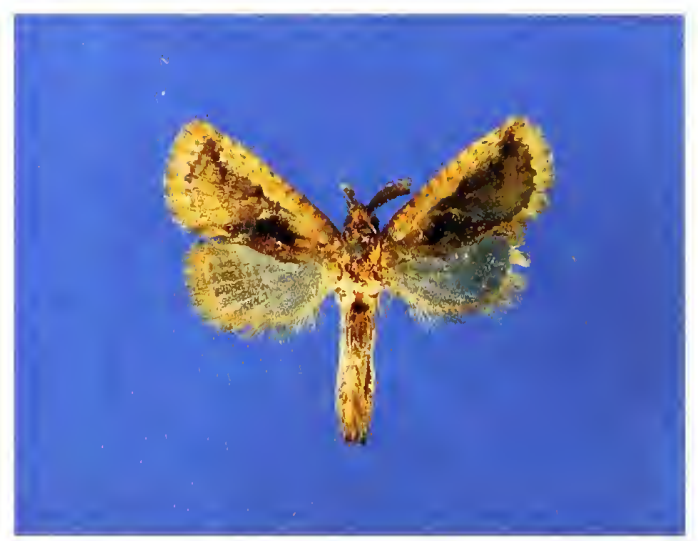

$20 \mathrm{~mm}$
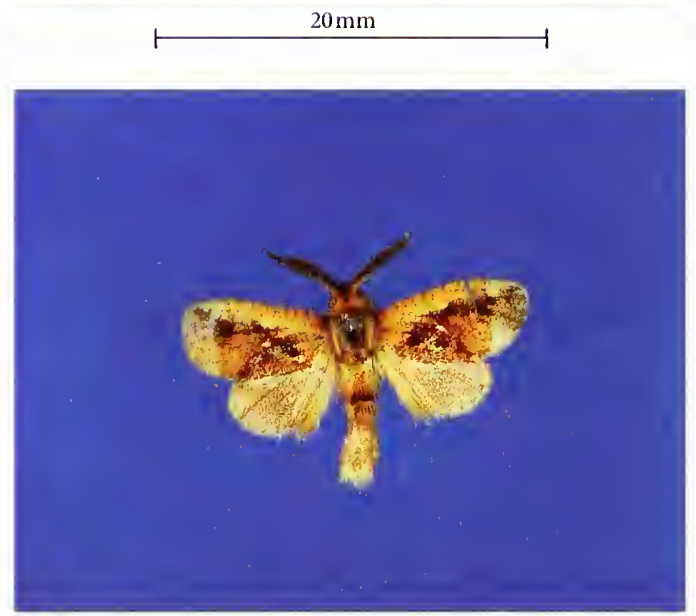

$20,5 \mathrm{~mm}$

Figure 22A. Moyencharia sommerlattei sp. nov., male, holotype, Republic of Guinea, locality unknown.

Figure 23A. Moyencharia ochreicosta (Gaede, 1929), male, holotype, Ghana, Volta Region, Kete-Krachi (formerly Kete-Kratje).

Figure 24A. Moyencharia ochreicosta (Gaede, 1929), female, Burkina Faso, Hauts-Bassins Region, Kourignon (near Nbié).

Figure 25A. Moyencharia ochreicosta (Gaede, 1929), male, Burkina Faso, Hauts-Bassins Region, Kourignon (near Nbié).

Figure 26A. Moyencharia ochreicosta (Gaede, 1929), male, Nigeria, Niger State, Zungeru.

Figure 27A . Moyencharia ochreicosta (Gaede, 1929), „,f. fuscoradiata det. M. Gaede,“ male, Ghana, Northern Region, Gambaga. 


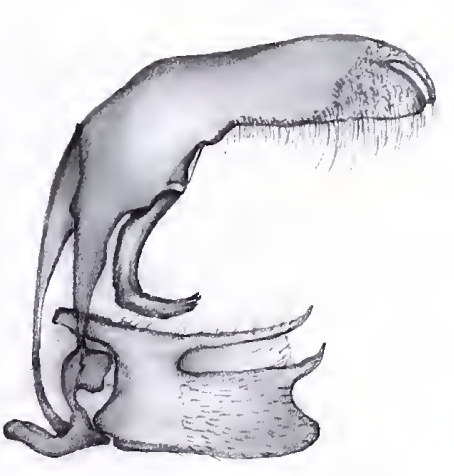

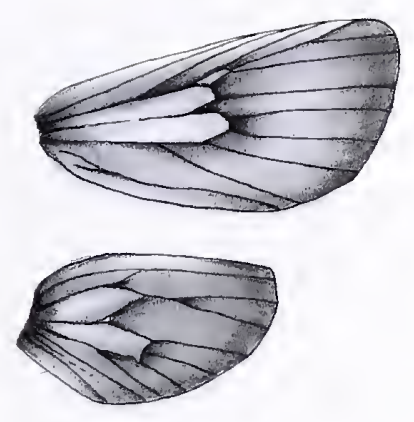

$5 \mathrm{~mm}$

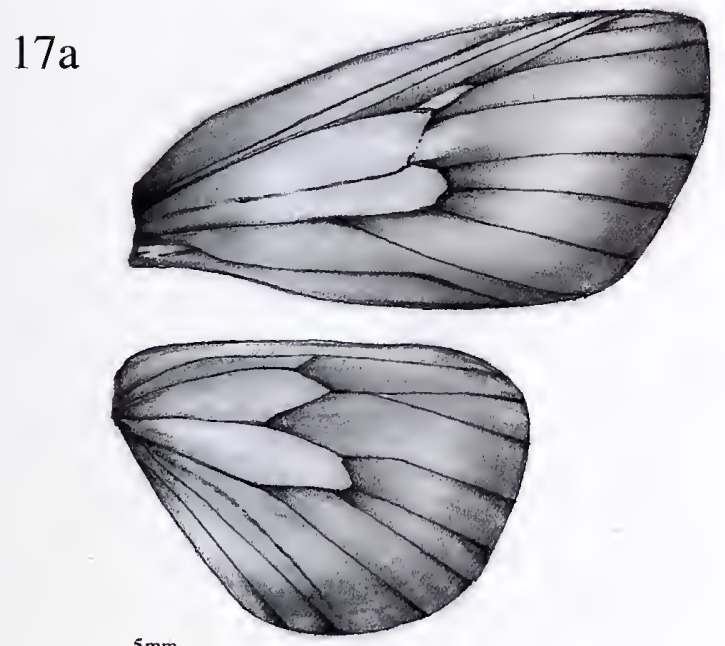

$5 \mathrm{~mm}$

$18 \mathrm{a}$

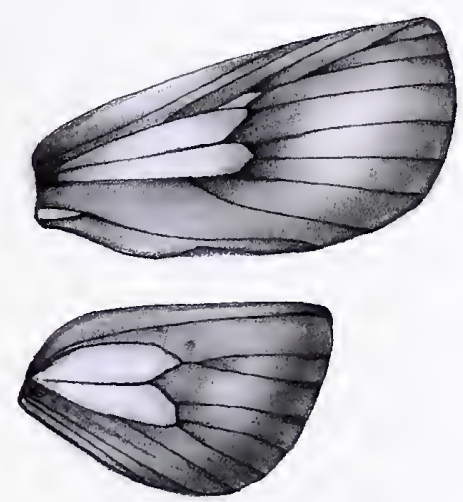

$5 \mathrm{~mm}$

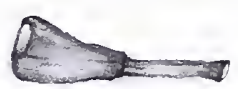

$1 \mathrm{~mm}$

\section{$17 \mathrm{~b}$}
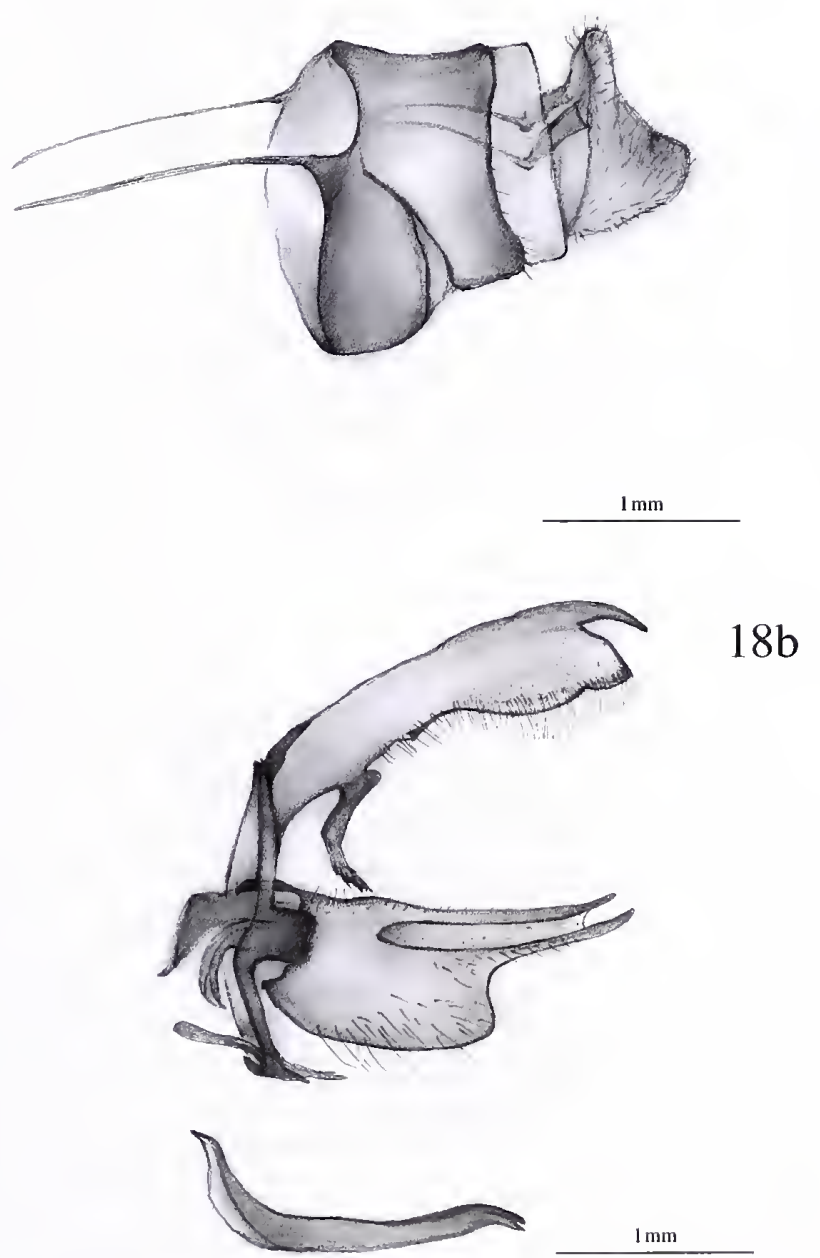

Figure 16a. Wing venation of: Moyencharia mineti sp. nov., male, holotype. 17a. Moyencharia mineti sp. nov., female, paratype. 18a. Moyencharia joeli sp. nov., male, holotype.

Figure 16b. Genitalia of: Moyencharia mineti sp. nov., male, holotype. 17b. Moyencharia mineti sp. nov., female, paratype. 18b. Moyencharia joeli sp. nov., male, holotype. 

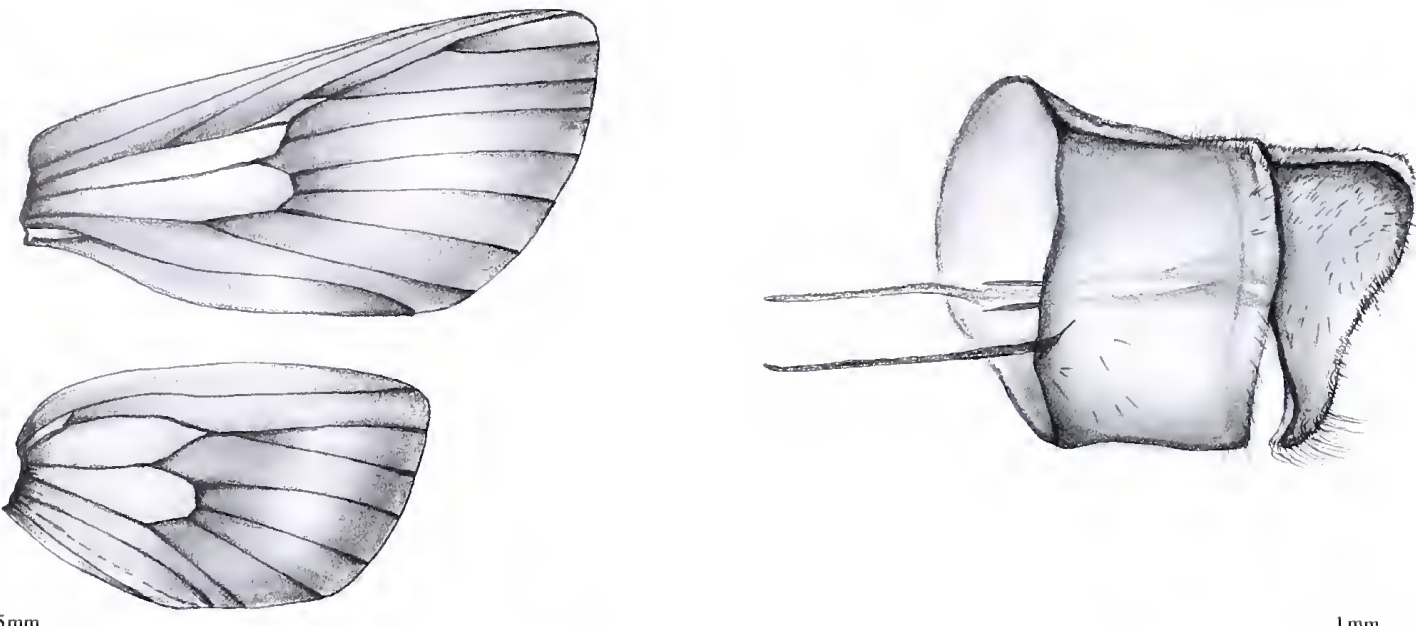

$20 \mathrm{a}$
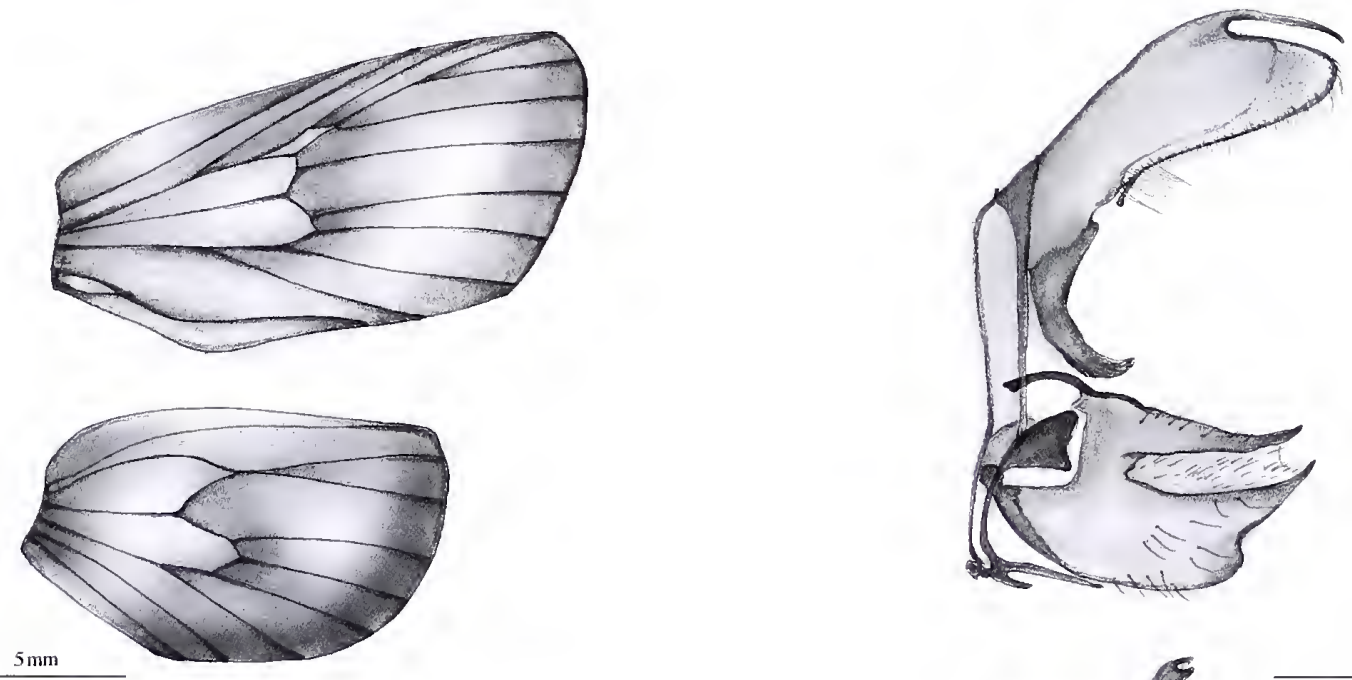

$20 \mathrm{~b}$

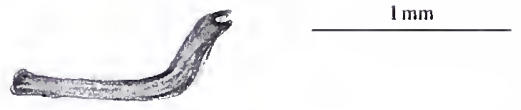

$21 \mathrm{a}$
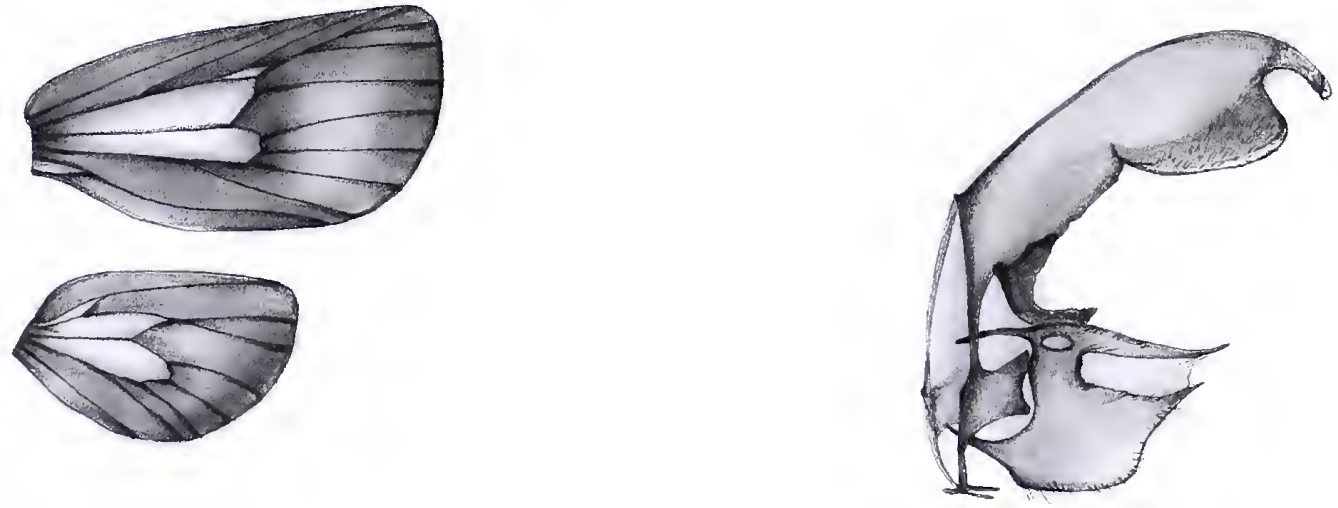

$\longrightarrow$

Figure 19a. Wing venation of: Moyencharia winteri sp. nov., female, holotype. 20a. Moyencharia herhausi sp. nov., male, holotype. 21 a. Moyencharia sommerlattei sp. nov., male, holotype.

Figure 19b. Genitalia of: Moyencharia winteri sp. nov., female, holotype. 20b. Moyencharia herhausi sp. mov., male, holotype. 21b. Moyencharia sommerlattei sp. nov., male, holotype. 
$22 \mathrm{a}$

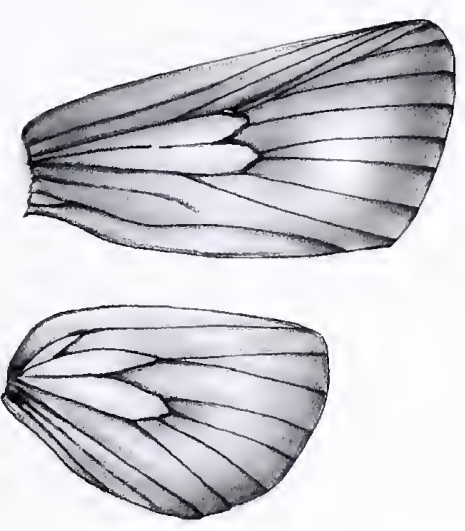

$5 \mathrm{~mm}$

\section{$23 \mathrm{a}$}

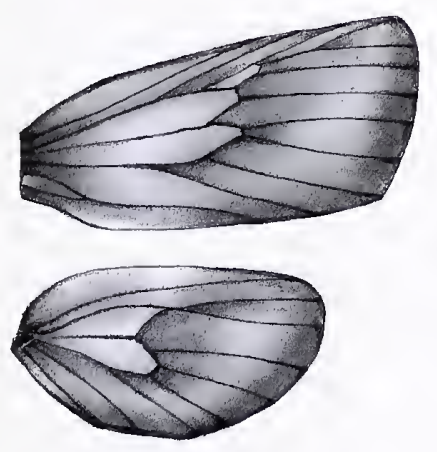

$5 \mathrm{~mm}$

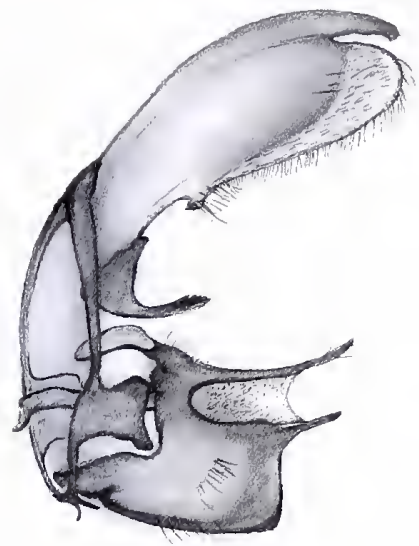

$22 b$

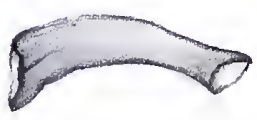

$1 \mathrm{~mm}$

$23 b$

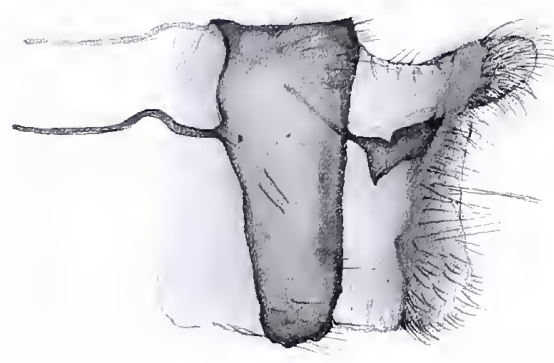

Figure 22a. Wing venation of: Moyencharia ochreicosta (Gaede, 1929), male. 23a. Moyencharia ochreicosta (Gaede, 1929), female.

Figure 22b. Genitalia of: Moyencharia ochreicosta (Gaede, 1929), male. 23b. Moyencharia ochreicosta (Gaede, 1929), female. 


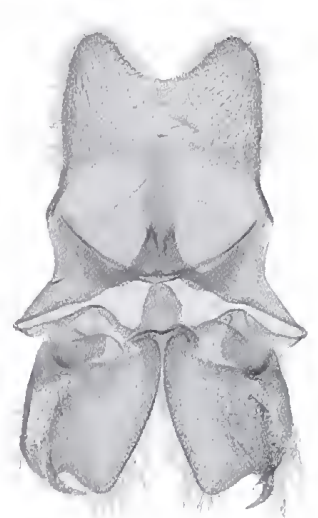

$1 \mathrm{~mm}$

$24 \mathrm{c}$

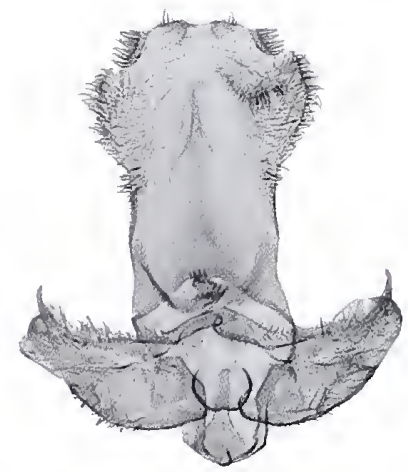

$1 \mathrm{~mm}$

$24 \mathrm{e}$

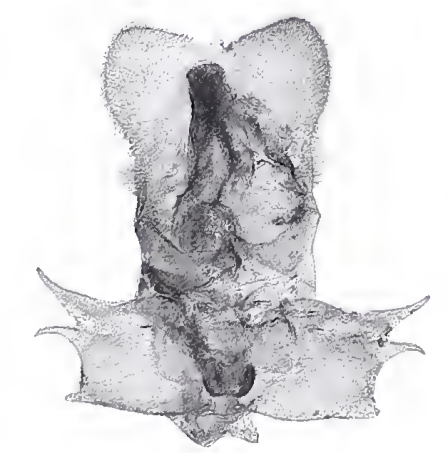

$1 \mathrm{~mm}$
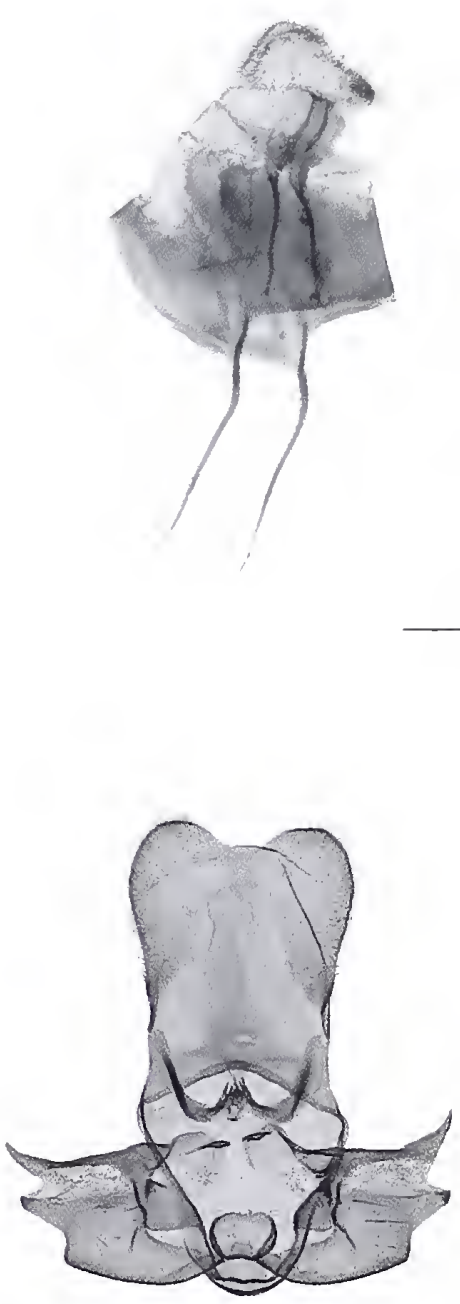

$1 \mathrm{~mm}$

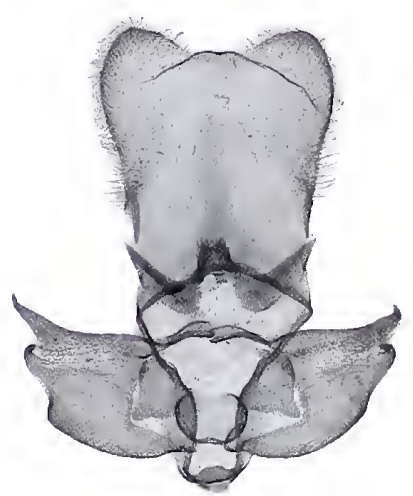

Figure 24a. Genitalia (ventral view) of: Moyencharia mineti sp. nov., male, holotype. 24b. Moyencharia mineti sp. nov., female, paratype. 24c. Moyencharia joeli sp. nov., male, holotype (the uncus is broken towards the tips). 24d. Moyencharia herhausi sp. nov., male, holotype. 24e. Moyencharia sommerlattei sp. nov., male, holotype. 24f. Moyencharia ochreicosta (Gaede, 1929), male (genitalia identical with holotype). 


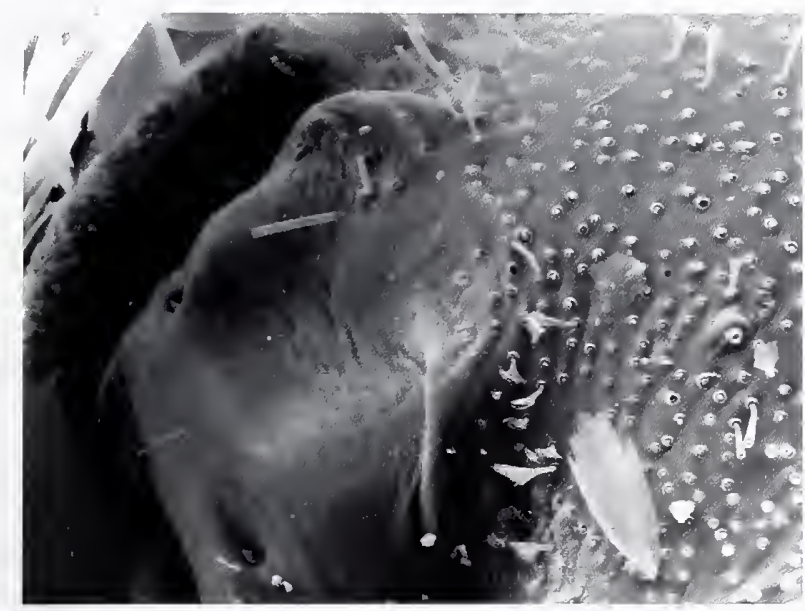

$100 \mu \mathrm{m}$

27

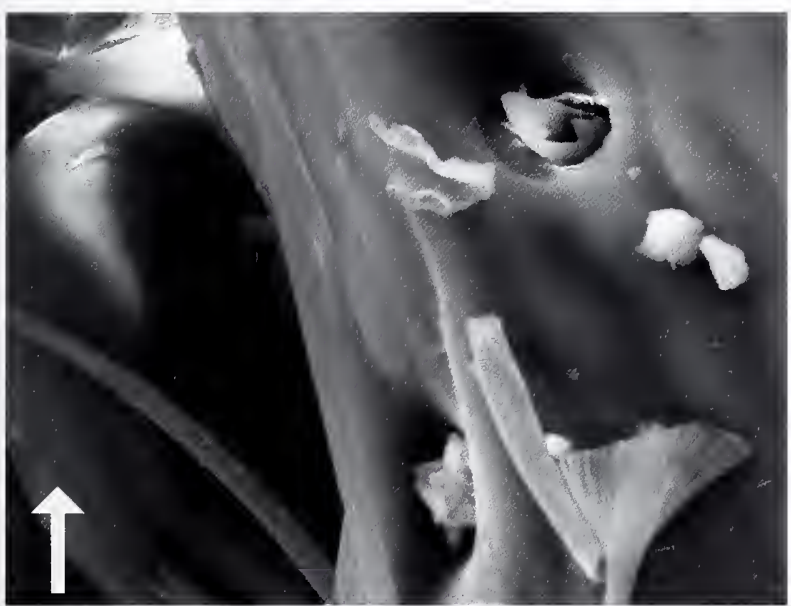

$0 \mu \mathrm{m}$

29

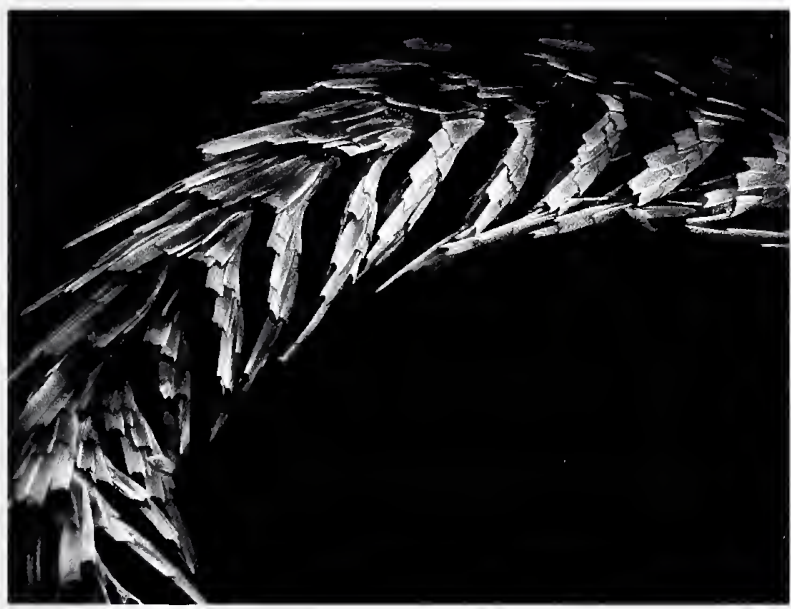

$200 \mu \mathrm{m}$

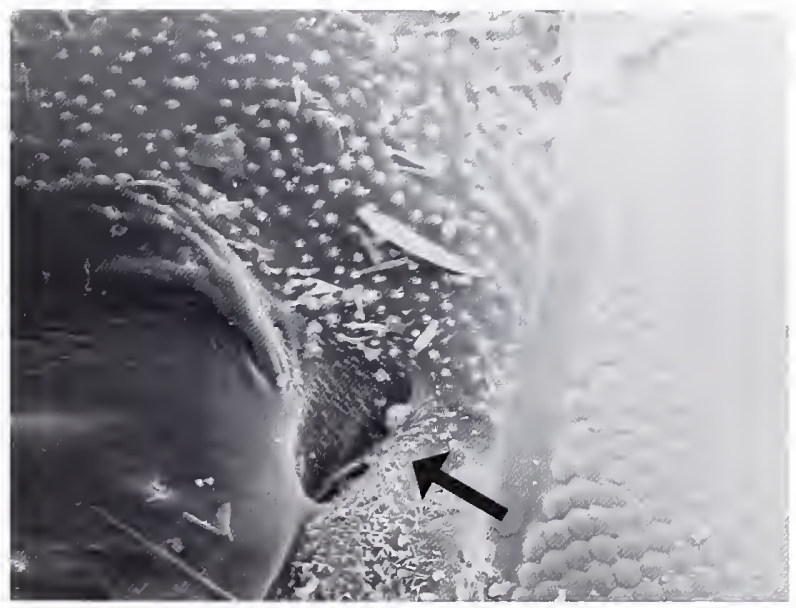

$100 \mu \mathrm{m}$

28

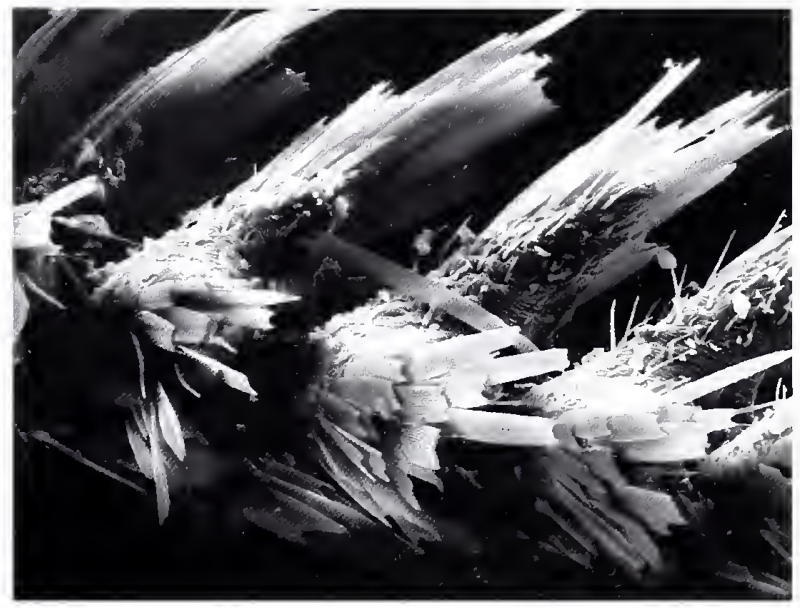

$80 \mu \mathrm{m}$

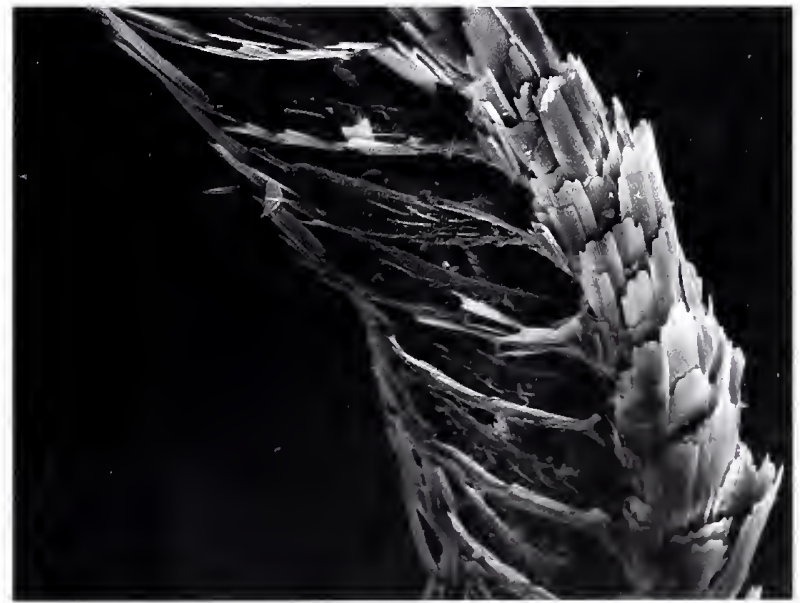

$100 \mu \mathrm{m}$

Figures 25-30. Details of Moyencharia mineti sp. nov., female, paratype.

25 . Head of $\%$, the frontoclypeus has neither projections nor pits (lateral view).

26. Head of $\%$, frontoclypeal structure with an oval shaped, small, rather flat pit ( $c$. arrow) behind the labial palpus (the latter is absent on the picture).

27. Head of 9 , the large lip-like structure on the lower frontoclypeus is remarkable ( $c f$. arrow).

28 . Head of $\$$, antenna with rather bipectinate structure (lateral view).

29. Head of $\%$, the densely scaled antenna shaft and branches (dorsal view).

30. Head of 9 , antenna branches (lateral view). 


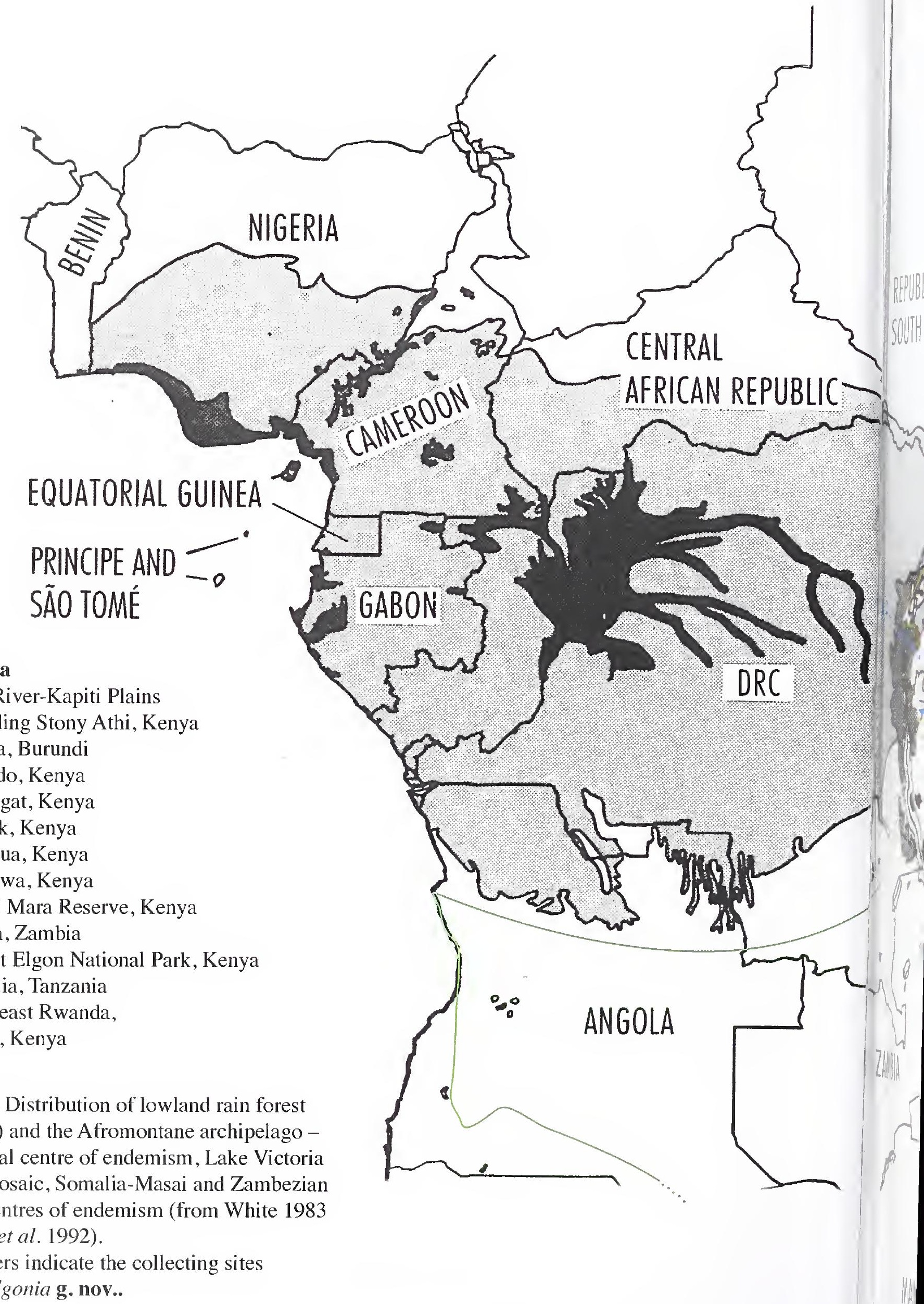




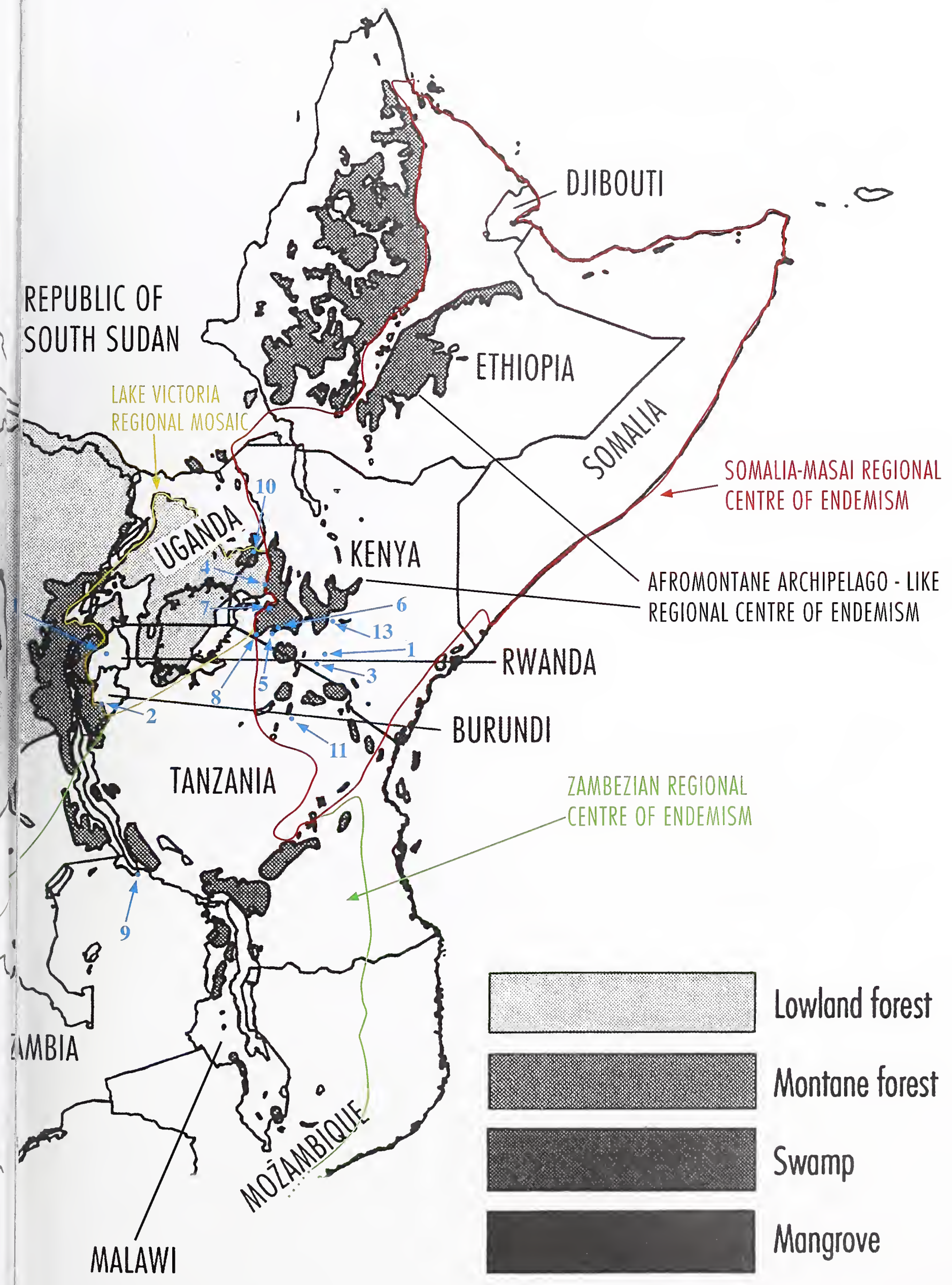




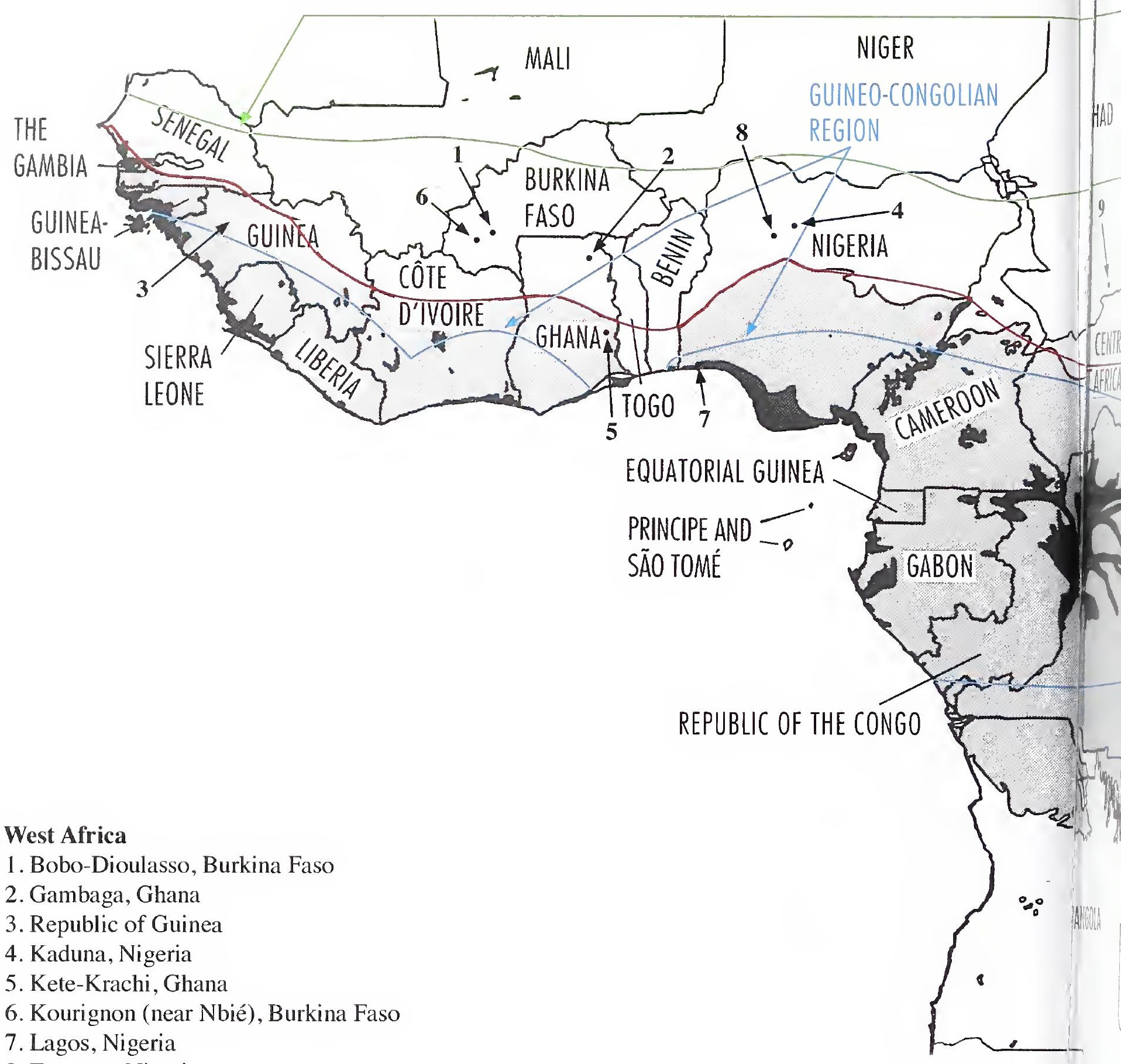

8. Zungeru, Nigeria

\section{North-Central Africa}

9. Makoga, Canton de Gondey, Chad

10. Moto, Democratic Republic of the Congo (DRC)

11. Tambura, Republic of South Sudan 
MUSEUM H BRAPY

02 MAY 2013

PRESENTED 
